\title{
ENVIRONMENTAL POLLUTION WITH HEAVY METALS IN THE REPUBLIC OF MACEDONIA
}

\author{
Trajče Stafilov \\ Institute of Chemistry, Faculty of Natural Sciences and Mathematics, Ss. Cyril and Methodius University, \\ Skopje, Republic of Macedonia \\ e-mail: trajcest@pmf.edu.mk
}

\begin{abstract}
An overview to the results from the application of various spectrometric (atomic absorption spectrometry, AAS; inductively coupled plasma - atomic emission spectrometry, ICP-AES; and inductively coupled plasma - mass spectrometry, ICP-MS) and radioanalytical (neutron activation analysis, NAA) techniques in environmental pollution studies in the Republic of Macedonia are presented. The results from the surveys of the pollution with heavy metals of soil, air and food are reported. The pollution with heavy metals in the particular regions was additionally investigated using moss, lichens, attic dust, soil, water and sediment samples. The results from the study of the pollution in the cities of Veles (lead and zinc smelter plant), Kavadarci (ferronickel smelter plant), Radoviš (copper mine and flotation), Probištip, Makedonska Kamenica and Kriva Palanka (lead and zinc mines and flotation plants) and Bitola and Kičevo (thermoelectric power plants) are presented.
\end{abstract}

Key word: heavy metals; pollution; air; soil; water; sediments; moss; attic dust; lichens; Republic of Macedonia

\section{INTRODUCTION}

Emissions of heavy metals into the environment happen through several processes. The emission of heavy metals into the atmosphere is one of the greatest threats to human health. People are directly exposed to the effects of heavy metals through inhalation of airborne microparticles from atmospheric dust [1]. Atmospheric particles affect the human health when they enter the respiratory system. The depth of penetration and deposition of particles depends on the size of particle, the defence capabilities of the respiratory tract and the respiratory pattern [2]. Exposure to heavy metals is possible if there is a coexistence of heavy metals and people. Exposure is usually defined as a function of the pollutant content and time, i.e. that it is "an appearance achieved by direct contact between humans and the environment with the pollutant content in a given interval of time" [1]. The health effects of heavy metals distributed with air-dust depend on their mass concentration and where they are deposited in the respiratory tract. The most exposed group of population to air particles are children, because the particles penetrate deeper in their lungs as compared to adults since children breathe deeper and faster, they spend more time outdoor and they are more active. The polluted air slows down the development of pulmonary functions in children [3]. Senior citizens, especially those with a weakened cardiovascular and respiratory system are a high risk group too. Another risk group is patients with chronic pulmonary emphysema, asthma or cardiovascular diseases [4].

Air pollution with heavy metals is a global process that affects every part of the globe. Rapid increases of heavy metal concentrations in the atmosphere and environment are commonly coupled to the development of exploitative technologies. This kind of sudden change exposes the biosphere to a risk of destabilization, to organisms that developed under conditions with low concentrations of metal, and presently have not developed biochemical pathways capable of detoxifying the metal when 
it is present at high concentrations. Atmospheric deposition of heavy metals is the main subject of many studies and usually occurs in industrialized areas, in places where exploitation and processing of natural resources (oil, ore, etc.) are performed, in areas with large population centers where traffic and municipal waste are the main sources of metals, etc. [5]. Heavy metals in the atmosphere originate mainly from dust dispersion from metal refining, fossil fuel combustion, vehicle exhausts, and other human activities and stay in the atmosphere until they are removed by a variety of cleansing processes. Particular emphasis is given on ore deposits, mining, and smelter plants as significant anthropogenic sources of dust. Heavy metals emitted in the atmosphere by combustion processes usually have relatively high solubility and reactivity; especially under low-pH condition [6, 7]. They can be carried to places far away from the sources by wind, depending upon whether they are in gaseous form or as particulates. Metallic pollutants are ultimately washed out of the air by rain and deposited on the land.

Soils differ widely in their properties because of geologic and climatic variation over distance and time. Even a simple property, such as the soil thickness, can range from a few centimetres to many meters, depending on the intensity and duration of weathering, episodes of soil deposition and erosion, and the patterns of landscape evolution. Nevertheless, in spite of this variability, soils have a unique structural characteristic that distinguishes them from mere earth materials and serves as a basis for their classification: a vertical sequence of layers produced by the combined actions of percolating waters and living organisms [1].

The abundance of heavy metals in soil has been increased dramatically by the accelerated rate of extraction of minerals and fossil fuels and by highly technological industrial processes. The problems of the degradation of the ecosystems due to pollution became increasingly acute during the latter decades of the 20th century. Most of the metals were typically found at very low total concentrations in pristine waters - for this reason they often are referred to as trace metals. Rapid increases of trace metal concentrations in the environment are commonly coupled to the development of exploitative technologies. This kind of sudden change exposes the biosphere to a risk of destabilization, since organisms that developed under conditions with low concentrations of a metal presently have not developed biochemical pathways capable of detoxifying that metal when it is present at high concentrations.
Urban pollution with heavy metals has recently become a subject of many studies [8-16]. The regional contamination of soil occurs mainly in industrial regions and within centres of large settlements where factories, motor vehicles and municipal wastes are the most important sources of trace metals [1]. Because of heterogeneity and ceaseless changing of urban areas, it is necessary first to understand the natural distribution and the methods for distinguishing man-made anomalies in nature. The natural background itself is variable, which means that higher concentrations of some elements can be normal for one region but anomalous for the other. However, there are cases when the industrial enterprises, especially mining and metallurgical plants, situated near cities can increase the pollution. It is obvious from the papers published recently that mining and metallurgical activities lead to enormous soil contamination [14, 15, 17-23].

Industrial activities which contribute to the environmental pollution with heavy metals in the Republic of Macedonia are mainly mining and metallurgical activities. Most of these industries use raw materials and/or auxiliary chemical substances in their operations. In many companies toxic, aggressive or flammable goods are used daily and thus hazardous and chemical wastes are generated. All these wastes are dangerous for human and the environment, often even in small quantities.

The goal of this paper is to present the results of studies which have aimed to investigate the level of the pollution of the environment (air, soil, waters, sediments) with heavy metals in the vicinity of the regions with anthropogenetic influence in the Republic of Macedonia. The special attention will be given to the air pollution in the Republic of Macedonia, as well as the environmental pollution in the specific mining and metallurgical areas. This applies especially to the mines areas: three lead and zinc mines and flotation plants (Zletovo, near the town of Probištip, Sasa, near Makedonska Kamenica, and Toranica, near Kriva Palanka), one copper mine and flotation plant (Bučim, near Radoviš), and one abandoned As-Sb-Tl mine (Allchar mine, near Kavadarci). Also, the results from the studies of the environmental pollution with heavy metals in the areas of four metallurgical plants will be presented: steel production in Skopje, ferronickel in Kavadarci, silicon alloys in Jegunovce, near Tetovo, and the abandoned $\mathrm{Pb}-\mathrm{Zn}$ smelter plant in the city of Veles (abandoned from 2002). All the activities of these mines and smelter plants in the past led to significant pollution in their vicinity and in some cases, in the wider environment. 


\section{AIR POLLUTION STUDIES OVER THE WHOLE TERRITORY OF MACEDONIA}

Atmospheric pollution represents solutions or suspensions of minute amounts of harmful compounds in the air [4]. The degree and extent of environmental changes over the last decades has given a new urgency and relevance for detection and understanding of environmental changes, due to human activities, which have altered global biogeochemical cycling of heavy metals and other pollutants [24-26]. The monitoring of toxic air pollutants is needed for understanding their spatial and temporal distribution and ultimately to minimize their harmful effects. In addition to direct physical and chemical methods of air pollution monitoring, bioindication has also been used to evaluate air pollution risk [4]. Heavy metals present only a part from a plurality of harmful compounds in air. The degree of metals extent and distribution in the air depend on the emissions frequency [27]. Air pollution with heavy metals present a global problem, but the hot spots occurs and influence on local level [28].

Mosses have been frequently used to monitor time-integrated bulk deposition of metals as a combination of wet, cloud, and dry deposition, thus eliminating some of the complications of precipitation analysis due to the heterogeneity of precipitation [29]. Mosses draw negligible amounts of water and minerals from the soil, and instead depend almost entirely on atmospheric inputs of nutrients. The metals are bound to the tissue with minimal translocation within the plant due to a lack of vascular tissue [30]. This results in biological tissue that can be analyzed to reveal time-integrated deposition [31]. Additional advantages of using mosses as heavy metal biomonitors include their stationary nature, widespread geographic distribution, and low genetic variability between populations.

Harmens and his European colleagues have found that mosses are reliable indicators of air pollution risks to ecosystems; because they get most of their nutrients directly from the air and rain, rather than the soil [28, 32, 33]. Since 2000 the European moss survey has been conducted by a special international programme (ICP Vegetation). Moss data provides a better geographic coverage than measured deposition data and can reveal more about actual atmospheric pollution at a local level (http://icpvegetation.ceh.ac.uk/).

The Republic of Macedonia was involved in the UNECE ICP Vegetation - Heavy Metals in European Mosses, for the first time in 2002 (survey 2000/2001) and again in 2005 and 2010 when atmospheric deposition of trace elements was studied over the entire territory of the country using samples of terrestrial mosses Hypnum cupressiforme and Homalothecium lutescens [34-37].

For that purpose, moss samples were collected from 72 locations over the entire territory of the country in accordance with the sampling strategy of the European moss survey program (Figure 1). The moss samples were digested by the application of microwave digestion system using nitric acid and hydrogen peroxide and then analyzed by neutron activation analysis (NAA), inductively coupled plasma - atomic emission spectrometry (ICP-AES) and atomic absorption spectrometry (AAS). To reveal hidden multivariate data structures and to identify and characterize different pollution sources Principal Component Analysis was used. Distributional maps were prepared to point out the regions most affected by pollution and related to known sources of contamination.

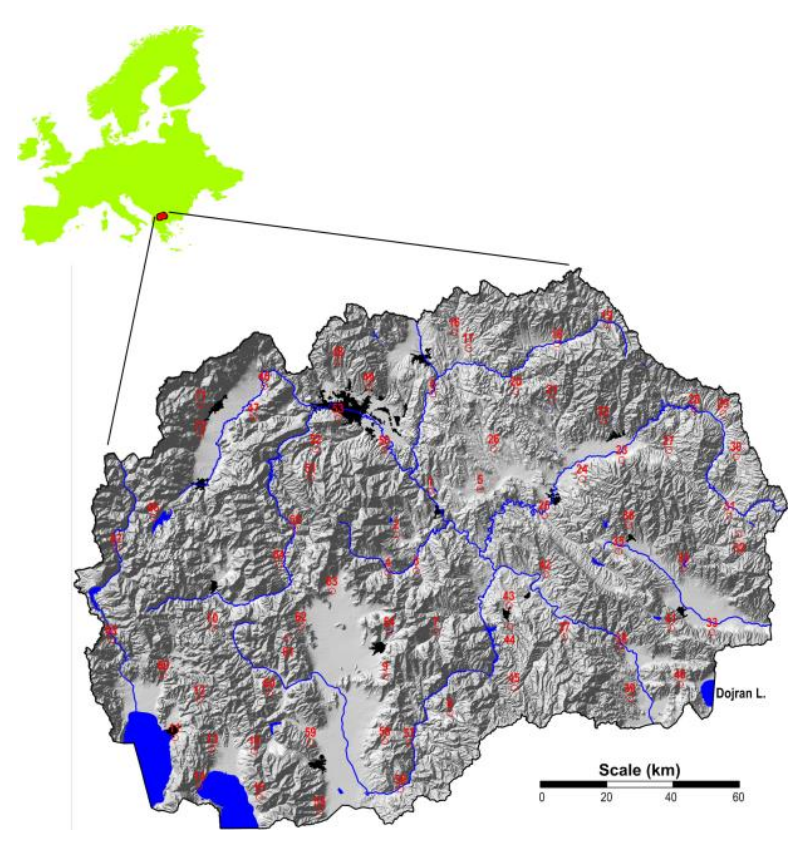

Figure 1. A map of Macedonia with a moss sampling locations

The results from all three studies show that the regions near the towns of Skopje, Veles, Tetovo, Radoviš and Kavadarci were found as most affected by pollution, even the median elemental contents in the mosses in 2010 for $\mathrm{Cd}, \mathrm{Cr}, \mathrm{Cu}, \mathrm{Ni}, \mathrm{Pb}$ and $\mathrm{Zn}$ were slightly lower then the previous surveys.

The results from the studies show that two anthropogenic associations of elements continuously appear including $\mathrm{Ag}, \mathrm{Cd}, \mathrm{In}, \mathrm{Pb}, \mathrm{Sb} \mathrm{Se}, \mathrm{Zn}$ and $\mathrm{Co}, \mathrm{Cr}, \mathrm{Cu}, \mathrm{Ni}$ [34-37]. It appears that the first association is connected mainly with a lead-zinc smelter in Veles and the $\mathrm{Pb}-\mathrm{Zn}$ mines in the eastern part of the country, and the second one with a ferro- 
nickel smelter plant in Kavadarci and copper mine near the town of Radoviš. These factors are dominant further along the valley of the Vardar river, extending from Skopje and continuing southeastwards to Greece. The same associations appear in the next two surveys in 2005 [36] and 2010 [37]. Even 7 years after closing the $\mathrm{Pb}-\mathrm{Zn}$ smelter plant in Veles there is still high content of these elements in moss samples from this region due to the presence of the open slag waste dump contributing to the pollution with $\mathrm{Cd}, \mathrm{Zn}$ and $\mathrm{Pb}$ (Figures 2 and 3). A zone with high values of $\mathrm{Cd}, \mathrm{Pb}$ and $\mathrm{Zn}$ (Figure 3) has been found in eastern parts of Macedonia as well, because of the operation of three lead and zinc mines (Sasa, Toranica and Zletovo) reactivated in the last 5-6 years. In the last several years the capacity of ferronickel smelter plant in Kavaradci (Figures 2 and 4) was increased several times which led to the very high content of nickel in moss from these region [16, 38-40].

It should be mentioned that one typical crustal composition association of elements $(\mathrm{Na}, \mathrm{Mg}$, $\mathrm{Al}, \mathrm{Sc}, \mathrm{Ti}, \mathrm{Fe}, \mathrm{Co}, \mathrm{As}, \mathrm{Rb}, \mathrm{Zr}, \mathrm{Cs}, \mathrm{Ba}, \mathrm{La}, \mathrm{Ce}, \mathrm{Sm}$, $\mathrm{Eu}, \mathrm{Tb}, \mathrm{Hf}, \mathrm{Ta}$, Th and $\mathrm{U}$ ) has been probably significantly influenced by soil particles adhered to the moss samples [35].
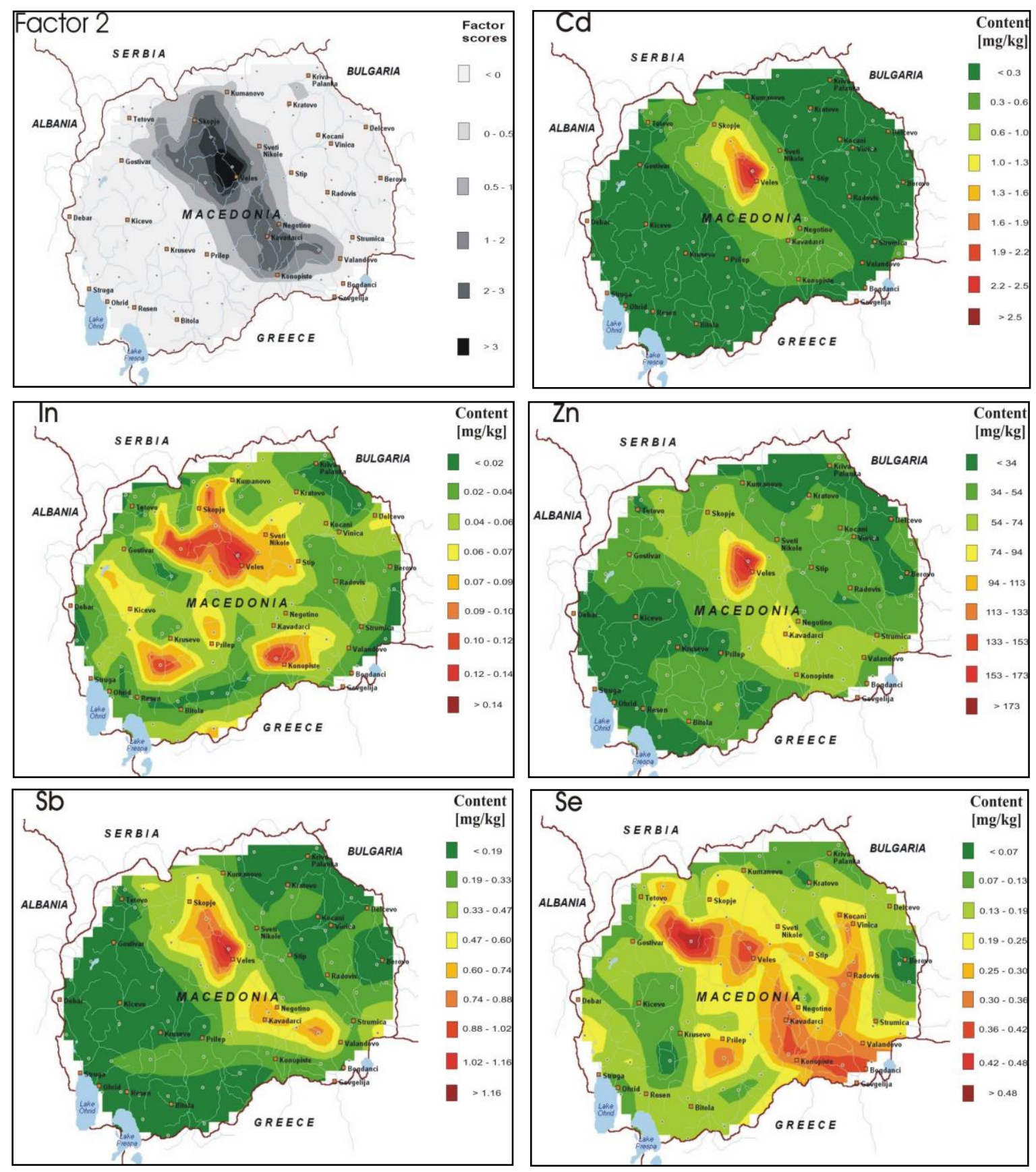

Figure 2. Distribution of Factor 2 (Cd, In, Zn, Sb, Se) in 2002 survey [34, 35] 
Particular interest is inherent with the data on atmospheric deposition patterns of uranium in moss in the vicinity of uranium deposits in the Republic of Macedonia. Distributions of uranium concentration in moss and soil [41] over the sampled territory are shown in Figure 5. The observed geographical anomalies seem to correspond to presence of the uranium minerals in some geochemical regions of Macedonia. However, the higher $U$ abundance in the southwestern part of the country (near the town of Bitola) is probably due to fly-ash deposition from the combustion of large amounts of lignite (about six million ton per year) [42] in the power plant near Bitola with air, and possibly also as a result of transboundary pollution from several power plants using the lignite type of coal in the north- ern part of Greece, just south of the Bitola power plant. It may be mentioned that in the Suvodol coal reservoir near Bitola, in the southwestern part of Macedonia, significant amounts of uranium minerals are also present [41]. Similarly, the appearance of uranium anomalies in moss in the region of Strumica (southeastern part of the country) coincides with the presence of significant amounts of uranium in granite deposits of this region [41]. During exploitation of these granites the process of drilling and milling of the rock may release considerable amounts of dust particles into the environment, also possibly trapped by the moss. The similar results were found in the studies in 2005 and 2010 (Figure 5).

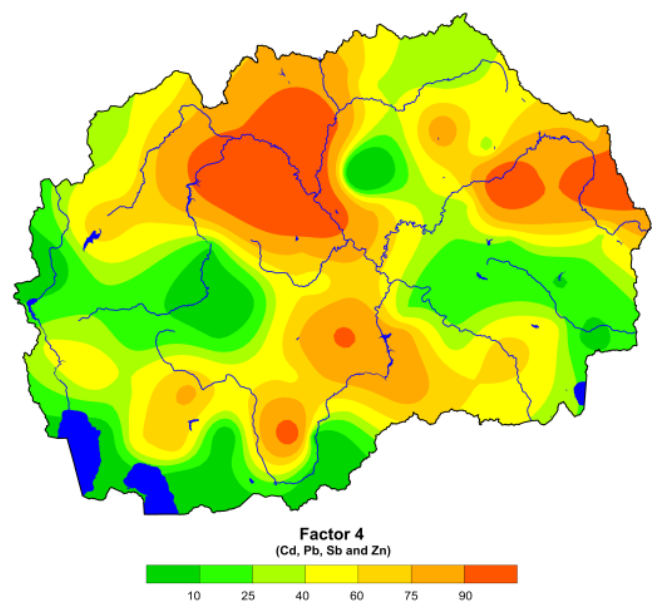

(a)

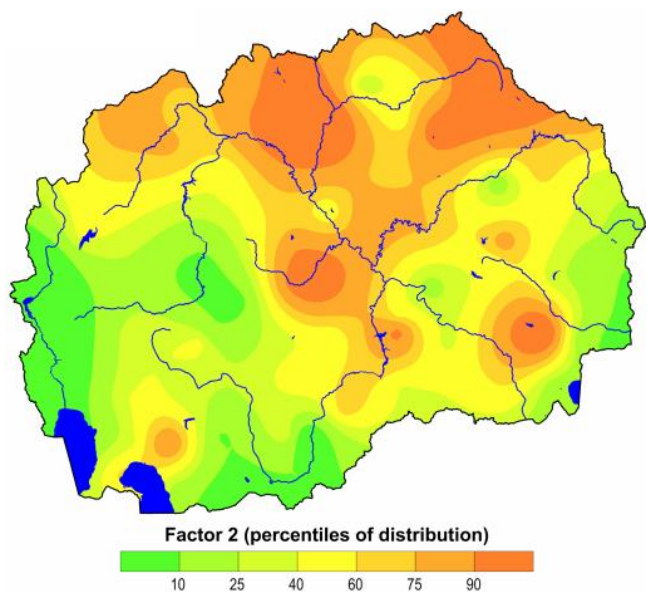

(b)

Figure 3. Spatial distribution of Factor $4(\mathrm{Cd}-\mathrm{Pb}-\mathrm{Sb}-\mathrm{Zn})$ (a) in moss survey from 2005 and Factor $2(\mathrm{Cd}-\mathrm{Cu}-\mathrm{Pb}-\mathrm{Zn})(\mathrm{b})$ in moss survey from $2010[36,37]$

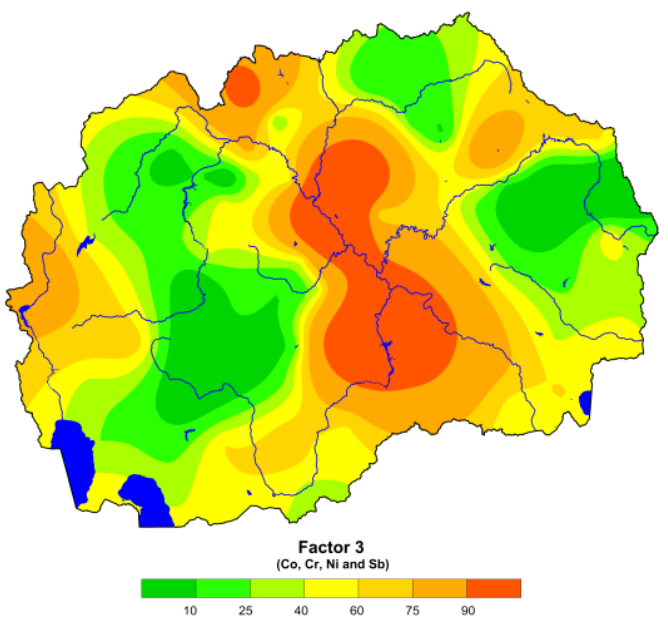

(a)

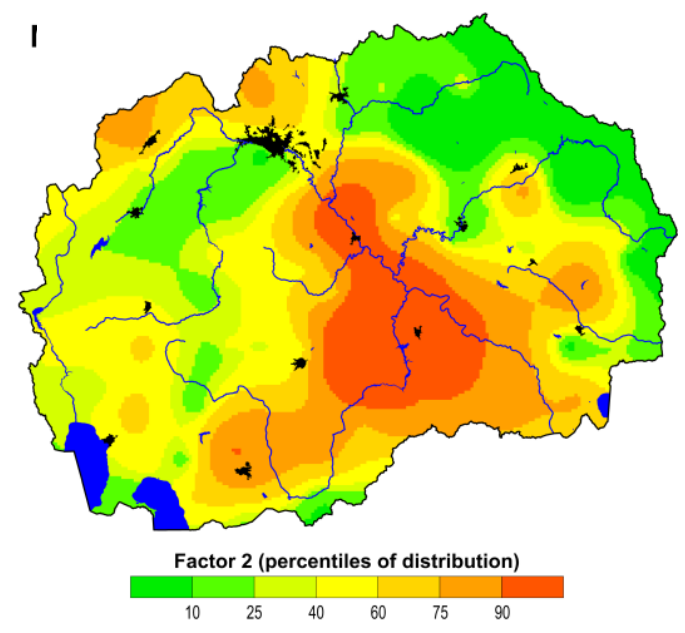

(b)

Figure 4. Spatial distribution of Factor 3 (Co-Cr-Ni-Sb) in moss survey from 2005 (a) and Factor 2 (Co-Cr-Ni) in moss survey from 2010 (b) [36, 37] 


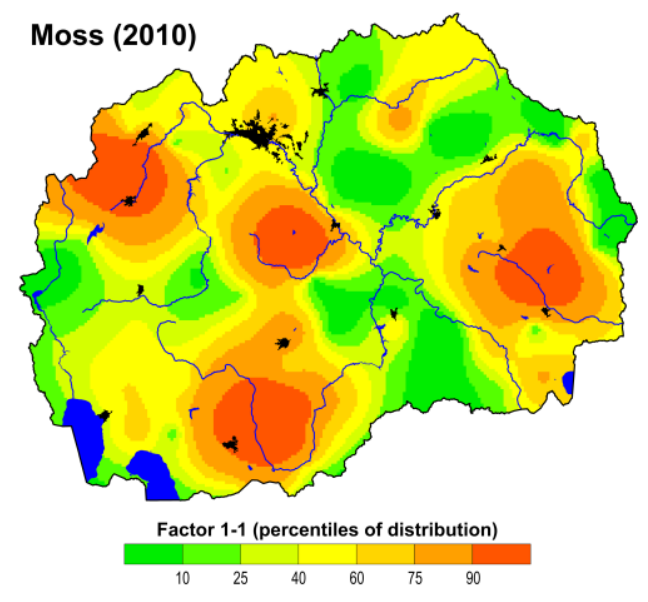

Figure 5. Spatial distribution of F1-1 factor scores (Sm-La-Yb-Tb-Ce-U-Th-Ta-Na-Dy-Nd-Hf-W-Al) [37]

\section{POLLUTION WITH HEAVY METALS IN VELES AND ITS ENVIRONS [15, 43-47]}

The town of Veles is located in the valley of the Vardar river, about $55 \mathrm{~km}$ south from the capital of Skopje. Veles, for many of its characteristics and features, is a specific urban and industrial area. The town is situated in the Vardar river valleys and it is surrounded by mountains and hills. The urban area is located on 160-200 m of altitude, surrounded by hills from both sides of the valley, and with a height difference between 300 and $675 \mathrm{~m}$. In 2002, 55000 inhabitants were registered in the municipality of Veles, while the town's population was 44000 .

Veles is the most polluted city in Macedonia due to the pollution from the lead and zinc smelter plant located in the town. The Macedonian Institute for Health Protection reported in 2003, when the factory was still in operation, that the capacity of the smelter plant was 62,000 tones of zinc, 47,300 tones of lead and 120,000 tones of sulfur dioxide annually [48]. It was also reported that these emissions lead to the increased concentrations of blood-lead levels in schoolchildren from Veles [49].

\section{Soil pollution in Veles and its environs}

Due to the emissions of dust with high content of heavy metals $(\mathrm{Pb}, \mathrm{Zn}$ and $\mathrm{Cd})$ from the plant, as well as from the slag deposit site it was expected that the surrounding soil will be also polluted with these elements. Therefore, the study for soil pollution with various elements was performed by Stafilov et al. [15, 43, 44]. Thus, the goal of the study was to determine as many elements as possible in the soil from the town of Veles and its surroundings, and to assess the size of the area affected by the lead and zinc smelter plant situated nearby.
The study area is large: $5.5(\mathrm{~W}-\mathrm{E}) \times 6.5$ (SN) km (Figure 6), and is located in the central part of Macedonia, which is limited with coordinates (Gauss Krueger zone 7) 7562750 (W) - 7568250 (E) and $4616750(\mathrm{~S})-4623250(\mathrm{~N})$. Of the total 35.8 $\mathrm{km}^{2}$ of the study area, the urban area occupies 5.5 $\mathrm{km}^{2}$ (settlements $4.2 \mathrm{~km}^{2}$ and industrial zone 1.3 $\mathrm{km}^{2}$ ), $17.3 \mathrm{~km}^{2}$ is cultivable land, $10.5 \mathrm{~km}^{2}$ is uncultivable land, and $2.5 \mathrm{~km}^{2}$ are forests.

For this purpose, a total of 201 soil samples were collected in 2006 from a dense grid $(0.25 \mathrm{~km}$ and $0.5 \mathrm{~km})$ in the urban area, and less dense grid (1 $\mathrm{km}$ ) in the rural area (Figure 6). The most characteristic elements for the given industrial activity $(\mathrm{Cu}$, $\mathrm{Cd}, \mathrm{Zn}, \mathrm{Hg}$ and $\mathrm{Pb}$ ) were determined by atomic absorption spectrometry (AAS), and a set of another 39 elements (Al, $\mathrm{Ca}, \mathrm{Fe}, \mathrm{K}, \mathrm{Mg}, \mathrm{Na}, \mathrm{Ti}, \mathrm{As}, \mathrm{Au}, \mathrm{Ba}, \mathrm{Br}$, $\mathrm{Ce}, \mathrm{Co}, \mathrm{Cr}, \mathrm{Cs}, \mathrm{Cu}$, Dy, Hf, In, La, Mn, Mo, Nd, Ni, $\mathrm{Rb}, \mathrm{Sb}, \mathrm{Sc}, \mathrm{Se}, \mathrm{Sm}, \mathrm{Sr}, \mathrm{Ta}, \mathrm{Tb}, \mathrm{Th}, \mathrm{Tm}, \mathrm{U}, \mathrm{V}, \mathrm{W}, \mathrm{Yb}$ and $\mathrm{Zn}$ ) by neutron activation analysis (NAA).

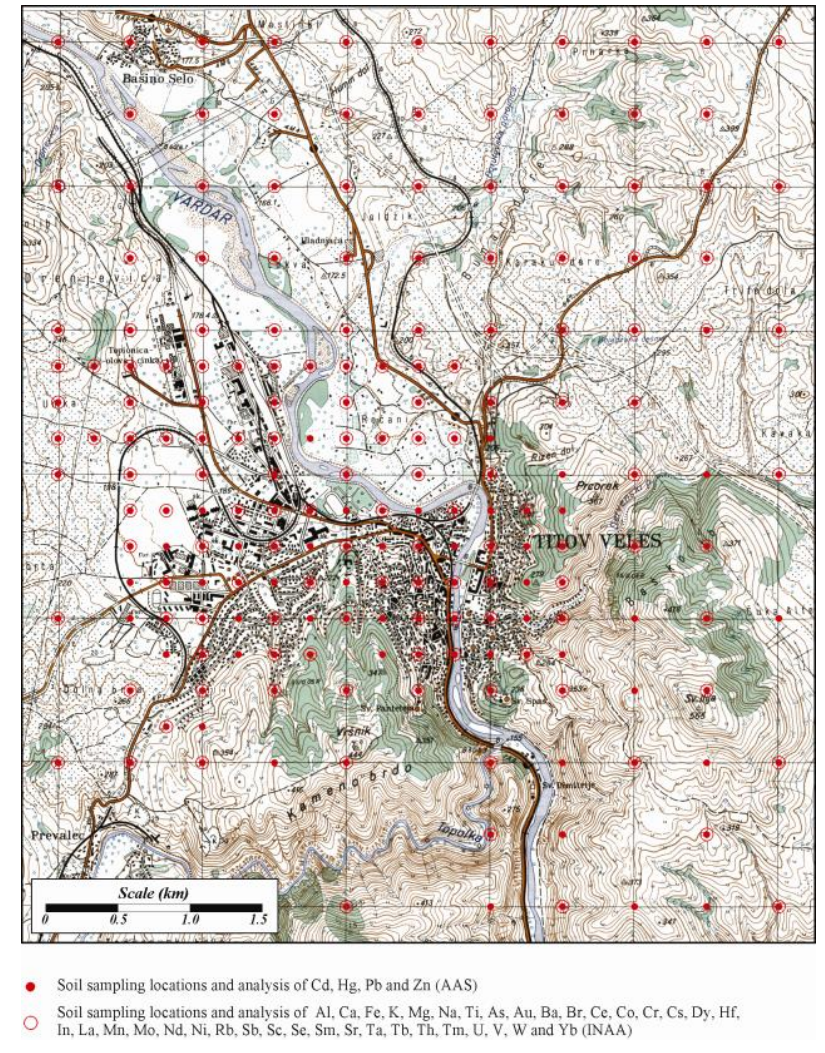

Figure 6. The study area and the location of the sampling points [15]

It was found that the content of the anthropogenic elements, such as $\mathrm{As}, \mathrm{Au}, \mathrm{Cd}, \mathrm{Cu}, \mathrm{Hg}, \mathrm{In}$, $\mathrm{Pb}, \mathrm{Sb}, \mathrm{Se}$ and $\mathrm{Zn}$, in the soil samples around the lead and zinc smelter and in the adjacent part of the town of Veles was much higher than in those collected in the surrounding areas due to the pollution 
from the plant (Figure 7). The enrichment of the elements in the topsoil, compared to the European [45] topsoil is typical for this elemental assemblage, from 2.2-times for $\mathrm{Sb}$ to 27-times for $\mathrm{Cd}$. High contents, as well as the enrichments of the mentioned elements, especially $\mathrm{Cd}$ in the topsoil, are noticeable close to the $\mathrm{Zn}$ smelter in Veles and in the urban zone. The highest determined concentrations of heavy elements in the polluted area are $600 \mathrm{mg} / \mathrm{kg}$ for $\mathrm{Cd}, 1.5 \%$ for $\mathrm{Pb}$, and $2.7 \%$ for $\mathrm{Zn}$. These concentrations reach into the percentage values and have to be considered very high. In the main polluted area the average concentration of $\mathrm{Cd}$ exceeds the European $\mathrm{Cd}$ average by more then 110 times!

The spatial distribution patterns of individual elements do not differ much (Figure 7). In the topsoil a clear anomaly occurs around the $\mathrm{Pb}-\mathrm{Zn}$ smel-

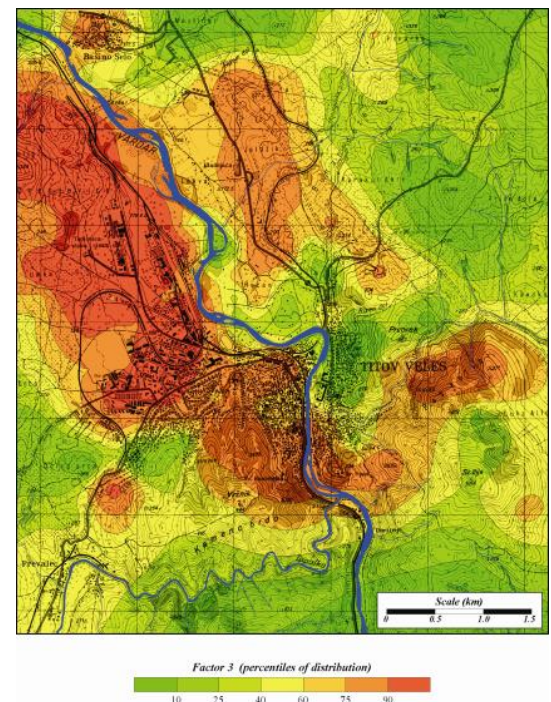

(a)

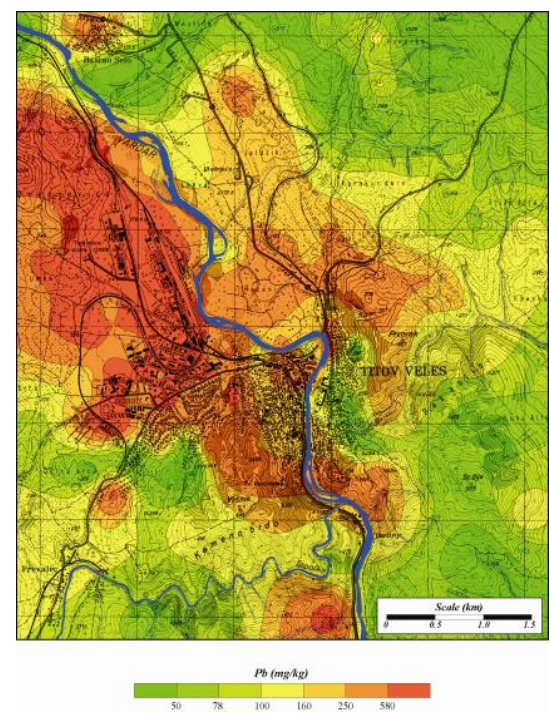

(c) ter in Veles and the urban area. The shape of the dispersion halo has been strongly influenced by the local winds and the shape of the Veles basin. Pollution with $\mathrm{As}, \mathrm{Cu}$ and $\mathrm{Hg}$ was deemed insignificant. According to our experimental results, the area critically polluted with $\mathrm{Cd}$ is about $6.6 \mathrm{~km}^{2}$, with $\mathrm{Pb}$ $4.2 \mathrm{~km}^{2}$ and $\mathrm{Zn} 3.8 \mathrm{~km}^{2}$. The content of any of the mentioned 6 chemical elements (As, $\mathrm{Cd}, \mathrm{Cu}, \mathrm{Hg}$, $\mathrm{Pb}$ and $\mathrm{Zn}$ ) exceeds the critical value in $6.8 \mathrm{~km}^{2}$.

The critically polluted area is of an ellipse shape that is a consequence of the wind rose [50]. It is important to mention that this research includes only the SW part of the critically polluted zone. It can be also concluded that the total pollution with heavy elements is a consequence of anthropogenic activity, more specifically, a result of operation of the lead and zinc smelter plant.

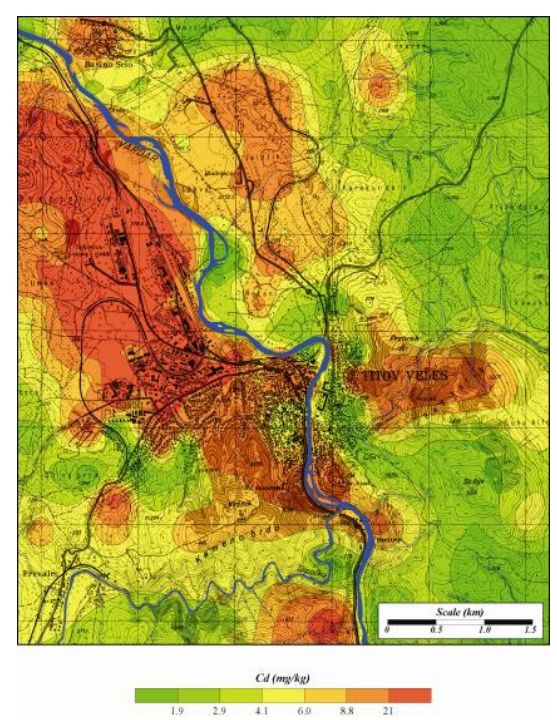

(b)

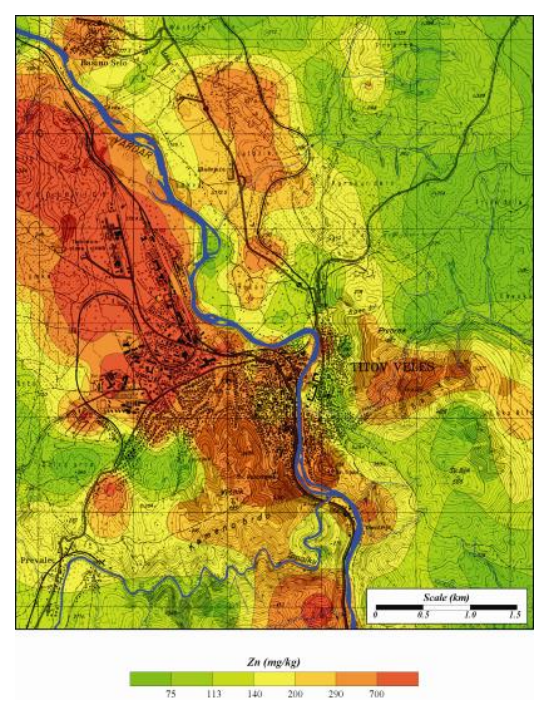

(d)

Figure 7. Distribution of the $\mathrm{F} 3$ association of the anthropogenic elements (As, $\mathrm{Cd}, \mathrm{Cu}, \mathrm{Hg}, \mathrm{In}, \mathrm{Pb}, \mathrm{Sb}$ and $\mathrm{Zn}$ ) (a) and distribution of $\mathrm{Cd}(\mathrm{b}), \mathrm{Pb}(\mathrm{c})$ and $\mathrm{Zn}(\mathrm{d})[15,43]$ 
The critically polluted area is of an ellipse shape, which is a consequence of the wind rose. The content of any of the mentioned elements (As, $\mathrm{Cd}, \mathrm{Cu}, \mathrm{Hg}, \mathrm{Pb}$ and $\mathrm{Zn}$ ) exceeds the critical value in about $7 \mathrm{~km}^{2}$ (Figure 8).

There is an assumption that the critically polluted zone is much larger. Therefore, our further investigations will be focused on the NE area in order to characterize the whole polluted territory.

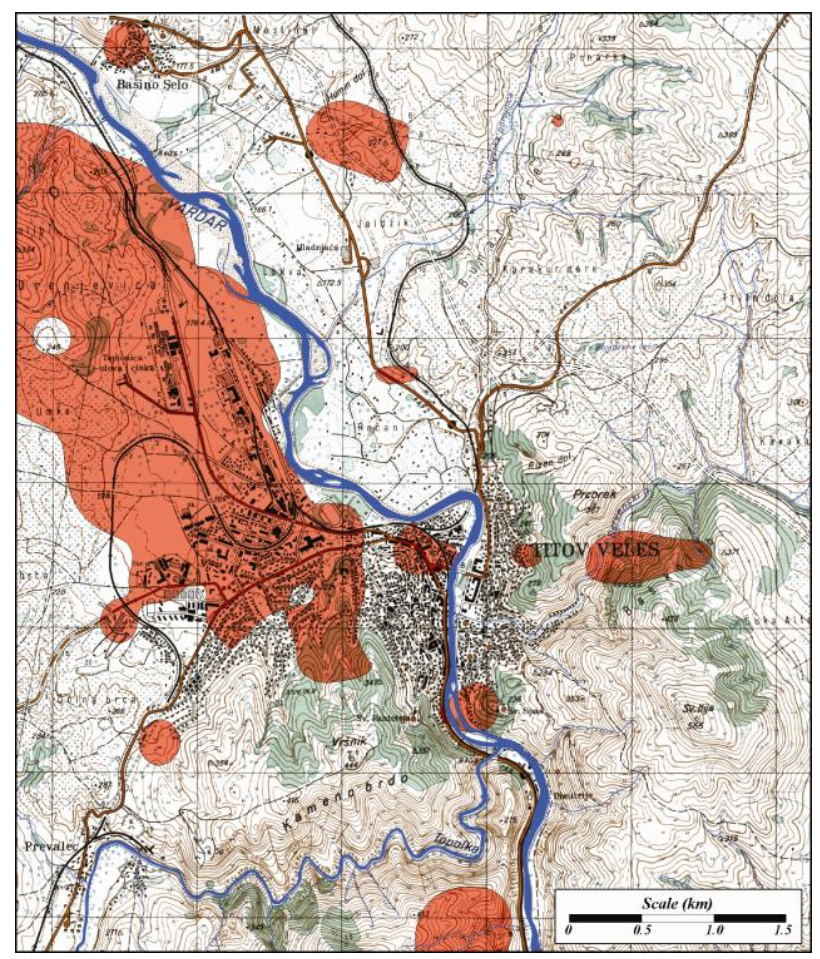

Figure 8. Critically polluted topsoil in the Veles area $[15,43]$

\section{Distribution of heavy metals in some vegeta- bles grown in the vicinity of lead and zinc smelter plant in Veles}

Gardens near the lead and zinc smelter plant "Zletovo" in the city of Veles, Republic of Macedonia, are the main suppliers with vegetables and fruits for the residents in the city of Veles. This area was exposed for thirty years to high environmental contamination with heavy metals $(\mathrm{Cd}, \mathrm{Pb}$ and $\mathrm{Zn})$. The smelter plant was a major source of heavy metals pollution including the gardens soil used for the production of vegetables and fruits. There are several studies of the analyses of heavy metals in vegetables produced in this area [46, 47, 51, 52].

The first study covers the analyses of lead and zinc [51] and Cd [52] in vegetables produced on various distance from the smelter plant. It was found that the contents of $\mathrm{Cd}$ and $\mathrm{Pb}$ in most of the collected vegetable samples were over the permitted limits even in those grown in the gardens located at a distance of $2 \mathrm{~km}$ from the smelter plant.

The recent study on the level of contamination (especially with $\mathrm{Cd}, \mathrm{Pb}$ and $\mathrm{Zn}$ ) concern to various vegetables (of lettuce, Lactuca sativa, carrot, Daucus carota, green garlic, Allium sativum and green onion, Allium scallion) produced on the contaminated soil $[46,47]$. The aim of the study was to determine the level of accumulation of heavy metals in the plants. The contents of 21 elements $(\mathrm{Ag}, \mathrm{Al}, \mathrm{As}, \mathrm{Ba}, \mathrm{Ca}, \mathrm{Cd}, \mathrm{Co}, \mathrm{Cr}, \mathrm{Cu}, \mathrm{Fe}, \mathrm{K}$, $\mathrm{Li}, \mathrm{Mg}, \mathrm{Mn}, \mathrm{Na}, \mathrm{Ni}, \mathrm{P}, \mathrm{Pb}, \mathrm{Sr}, \mathrm{V}$ and $\mathrm{Zn}$ ) in the vegetables and corresponding soils were analyzed by inductively coupled plasma - atomic emission spectrometry (ICP-AES) after microwave digestion.

It was confirmed that the heavy metals content in the studied soils resulted with high values for $\mathrm{Pb}$, $\mathrm{Zn}$ and $\mathrm{Cd}$. Thus, the content of cadmium in all four garden soils was over the target value of $0.8 \mathrm{mg} \mathrm{kg}^{-1}$, it varied from $1.39 \mathrm{mg} \mathrm{kg}^{-1}$ to $7.66 \mathrm{mg} \mathrm{kg}^{-1}$. The results for lead ranged from $46 \mathrm{mg} \mathrm{kg}^{-1}$ to $156 \mathrm{mg} \mathrm{kg}^{-1}$ (over the target value for lead of $85 \mathrm{mg} \mathrm{kg}^{-1}$ ), while the content of $\mathrm{Zn}$ was from $206 \mathrm{mg} \mathrm{kg}^{-1}$ to $231 \mathrm{mg}$ $\mathrm{kg}^{-1}$ (over the target value for $\mathrm{Zn}$ of $140 \mathrm{mg} \mathrm{kg}^{-1}$ ).

As a results of such high values for these elements in soil their content in the vegetables produced on these gardens was also high. Thus, the obtained results for lettuce and carrot were compared with the maximum permissible level according to the Macedonian regulations for food safety in fresh vegetables [53, 54]. If we compare the average value for $\mathrm{Cd}$ from the carrot samples $(0.32 \mathrm{mg}$ $\mathrm{kg}^{-1}$ ) it can be seen that the content of $\mathrm{Cd}$ in the carrot and lettuce is from 2 to 3.2 times higher than the permitted levels for $\mathrm{Cd}$ in fresh vegetable $(0.1$ $\mathrm{mg} \mathrm{kg}{ }^{-1}$ ) while the content of lead is from 1.6 to 10 times higher than the permitted level. Similar results were obtained in the case of garlic and onion samples. Thus, the contents of these heavy metals in fresh garlic and onion samples are very high compared to the national limits. The content of $\mathrm{Cd}$ was in the range of 0.06 to $0.28 \mathrm{mg} \mathrm{kg}^{-1}(1.2-3$ times higher than the permitted value), for $\mathrm{Pb}$ from 0.44 to $0.63 \mathrm{mg} \mathrm{kg}^{-1}$ (4.4-6.3 times over the limit) and for $\mathrm{Zn}$ from 1.19 to $3.05 \mathrm{mg} \mathrm{kg}^{-1}$.

\section{POLLUTION WITH HEAVY METALS IN KAVADARCI AND ITS ENVIRONS}

$$
[16,38-40,55,56]
$$

The town of Kavadarci is located in Tikveš Valley, about $100 \mathrm{~km}$ south from the capital of Skopje. The town is well known and famous by its vineyards, all over Macedonia and also in many European countries. The municipality of Kavadarci 
$\left(38,741\right.$ inhabitants; $\left.992 \mathrm{~km}^{2}\right)$ is made of the town of Kavadarci (28000 inhabitants) and 39 settlements. The Kavadarci region is also known for its ferronickel industrial activity in the nearest past, which is assumed as potential pollution sources with heavy metals. There were several investigations of soil, vegetables and fruits produced in this region but they were mainly concerned with contamination by nickel, iron, cobalt and chromium [57]. Other elements were not determined though it is known that the minerals of many other heavy metals (As, $\mathrm{Cd}, \mathrm{Cu}, \mathrm{Sb}, \mathrm{Se}$, etc.) are present in ironnickel ores used for the production of nickel in the smelter plants $[58,59]$. From the other side, the studies on the atmospheric deposition of trace metals over the entire territory of the Republic of Macedonia identified the most polluted areas and characterized different pollution sources and it was found that the most important sources of trace metal deposition are ferrous and non-ferrous smelters including the area of Kavadarci and its surroundings [34-37, 60].

\section{Soil pollution with heavy metals in Kavadarci and its environs}

The study concerning the determination of the content of 36 major and trace elements in the soil from the town of Kavadarci and its surroundings and to assess the size of the area eventually affected by the ferronickel smelter plant situated near the town was performed $[16,55,56]$. The subject of the study was to present the results of a first systematic study of spatial distribution of different elements in surface soil over of the Kavadarci region, the Republic of Macedonia, known for its ferronickel industrial activity in the nearest past. This smelter plant uses the nickel ore with a content of around $1 \%$ of $\mathrm{Ni}$ from the Ržanovo mine, about $30 \mathrm{~km}$ south of the plant. The Ržanovo ore body has the following lithological rock types: hematite, magnetite-ribecite schists, dolomite-talc schists, talc schists and serpentine [61]. In the last 5-6 years beside ore from Ržanovo mine, ore from Indonesia (saprolite-limonite type) reach in nickel $(2-2.5 \%)$ and from some other countries was used. Therefore, the dust from this plant has the same content as the ore used as a raw material.

The complete investigated region $\left(360 \mathrm{~km}^{2}\right)$ is covered by a sampling grid of $2 \times 2 \mathrm{~km}^{2}$; in the urban zone and around the ferronickel smelter plant $\left(117 \mathrm{~km}^{2}\right)$ the sampling grid is denser, $1 \times 1 \mathrm{~km}^{2}$ (Figure 9). All together, in 172 locations 344 soil samples were collected in 2008. At each sampling point were collected soil samples at two depths, topsoil $(0-5 \mathrm{~cm})$ and bottom $(20-30 \mathrm{~cm})$ soil.

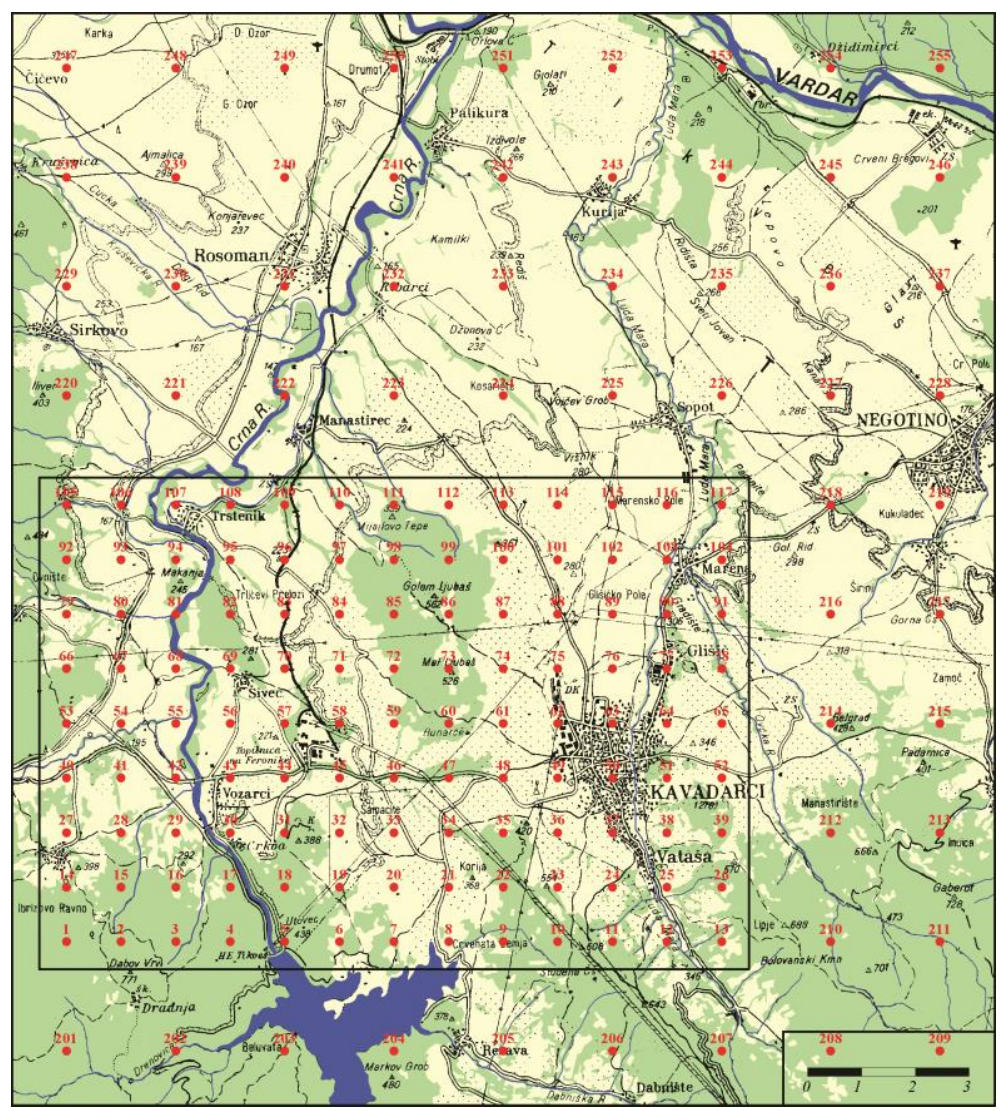

Figure 9. Soil samples locations in the Kavadarci area [16] 
Inductively coupled plasma - mass spectrometric (ICP-MS) determinations of 36 elements (Ag, $\mathrm{Al}$, As, $\mathrm{Au}, \mathrm{B}, \mathrm{Ba}, \mathrm{Bi}, \mathrm{Ca}, \mathrm{Cd}, \mathrm{Co}, \mathrm{Cr}, \mathrm{Cu}, \mathrm{Fe}, \mathrm{Ga}$, $\mathrm{Hg}, \mathrm{K}, \mathrm{La}, \mathrm{Mg}, \mathrm{Mn}, \mathrm{Mo}, \mathrm{Na}, \mathrm{Ni}, \mathrm{P}, \mathrm{Pb}, \mathrm{S}, \mathrm{Sb}, \mathrm{Sc}, \mathrm{Se}$, Sr, Th, Tl, Ti, U, V, W and Zn) was performed.

After statistical data processing, four geogenic and three anthropogenic geochemical associations were established on the basis of: visually indicated similarity of geographic distribution of elemental patterns in topsoil and subsoil, comparisons of the averages of particular chemical elements according to basic lithological units, the correlation coefficient matrix and the results of factor analyses and comparisons of the enrichment ratios.

The distributions of elements that reflect natural processes are indicated by elements that are rarely or never included in industrial processes. Their contents usually change gradually across the landscape and depend on the geological background. Following the results of factor analysis and the trends shown on the geochemical maps, four natural geochemical associations in soil were defined. For naturally distributed geochemical association the concentration of chemical elements increases with soil depth.

The most characteristic association is that of high contents of $\mathrm{Al}, \mathrm{Fe}, \mathrm{Ga}$, Sc and $\mathrm{V}$ as assembled in Factor 1. Their sources are mainly natural phenomena, such as rock weathering and chemical processes in soil. The association illustrated by Factor 2 consists of contributions of $\mathrm{Co}, \mathrm{Cr}, \mathrm{Mg}$ and $\mathrm{Ni}$. Similarly to the example of distribution of the Factor 1 scores, the spatial distribution of Factor 2 scores $(\mathrm{Co}, \mathrm{Cr}, \mathrm{Mg}$ and $\mathrm{Ni}$ ) in both soil layers is also closely dependent on the lithogenesis. Their highest contents were found in areas of Paleozoic and Mesozoic rocks and Eocene upper flysch zone and their lowest values in area of the Pleistocene tuff, Holocene diluvium and Holocene alluvium. These findings are also confirmed by the average enrichment ratios of $\mathrm{Co}, \mathrm{Cr}, \mathrm{Mg}$ and $\mathrm{Ni}$. In the area of Paleozoic and Mesozoic rocks, their average concentrations exceed the average of the investigated area by more than twice (Figure 10).

The third naturally distributed geochemical association consists of $\mathrm{Ba}, \mathrm{La}$, Th and $\mathrm{U}$, elements that are also little affected by anthropogenic activities, and it is closely dependent on the lithogenesis. Their highest contents were found in areas of the Pleistocene tuff, Holocene diluvium and Holocene alluvium, and their lowest values in areas of the Eocene upper flysch zone and Paleozoic and Mesozoic rocks. The natural association of $\mathrm{Ca}$ and $\mathrm{Sr}$ is illustrated by Factor 4 and occurs in the areas of the Eocene upper flysch zone and Pliocene sandy series, while their lowest values in area of Paleozoic and Mesozoic rocks.

Anthropogenic distribution represents the pollution when chemical elements are introduced into environment through human activities. In the case of anthropogenically produced chemical elements, their concentrations can increase several times compare to the background that consists of minor elemental fluctuations. Typically for anthropogenically distributed geochemical association the concentration of chemical elements decreases with soil depth.
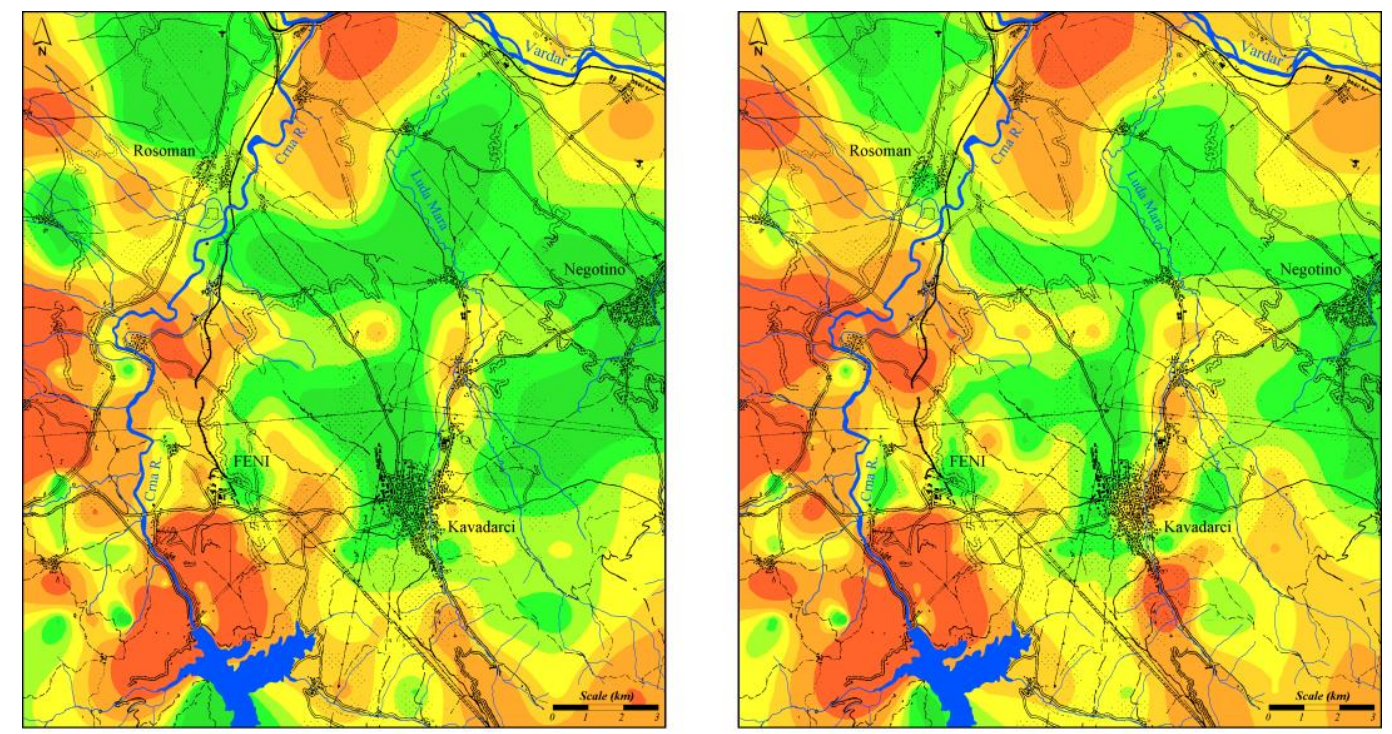

Factor 2 (percentiles of distribution)

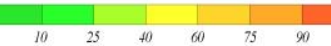

Figure 10. Distribution of Factor 2 scores $(\mathrm{Co}, \mathrm{Cr}, \mathrm{Mg}$ and $\mathrm{Ni})$ in topsoil (depth $0-5 \mathrm{~cm})$ and subsoil $(20-30 \mathrm{~cm})[16,55]$ 
The group comprises $\mathrm{Cd}, \mathrm{Hg}, \mathrm{Pb}$ and $\mathrm{Zn}$, chemical elements that were introduced into the environment through anthropogenic activities. The geochemical association is indicated by the Factor 5. Typical for this elemental assemblage is the enrichment of the elements in topsoil versus subsoil (Figure 11). High concentrations and the enrich- ments of these elements in topsoil are noticeable in the area of Paleozoic and Mesozoic rocks. The spatial distribution patterns of individual elements do not differ significantly. There is a clear anomaly in the top soil in the area of Paleozoic and Mesozoic rocks, in wider urban area of the town of Kavadarci and in the Holocene alluvium of the Vardar river.
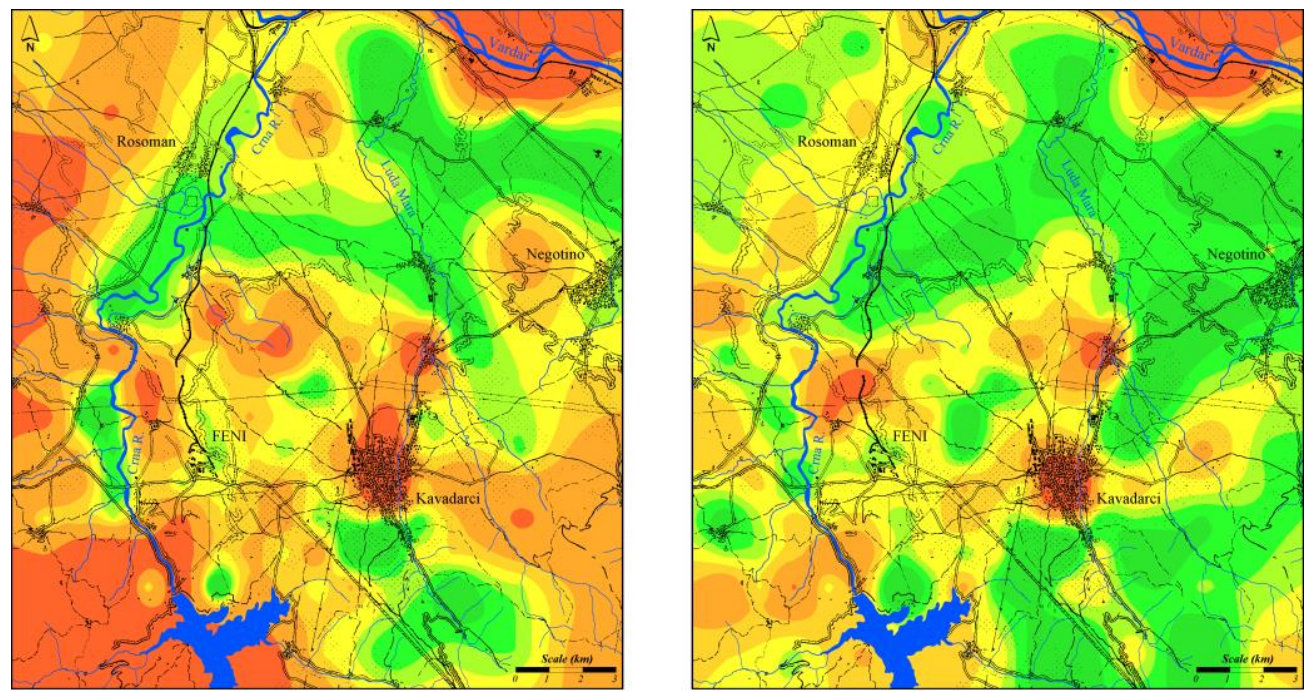

Factor 5 (percentiles of distribution)

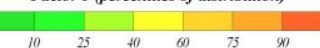

Figure 11. Distribution of Factor 5 scores $(\mathrm{Cd}, \mathrm{Hg}, \mathrm{Pb}$ and $\mathrm{Zn})$ in topsoil (depth $0-5 \mathrm{~cm})$ and subsoil $(20-30 \mathrm{~cm})[16,43]$

The association illustrated by Factor 6 (Figure 12) consists of contributions of As, Sb and Tl. It is interesting that the contents of $\mathrm{As}, \mathrm{Sb}$ and $\mathrm{Tl}$ are similar to the European averages (Salminen et al., 2005) or above them. Samples collected on Holocene alluvium of the Crna Reka river show high concentrations of the mention elements (Figure 12). Their average enrichment ratios exceed the average of the total investigated area by 4 to 4.5 times. The spatial distribution patterns of individual elements do not show a visible difference. In the topsoil there is a clear anomaly in the area of Holocene alluvium of the Crna and Vardar rivers (Figure 12). The enrichment of the Holocene alluvium of the river of Crna Reka with these elements is supposed to be a consequence of natural erosion from Allchar mine deposits on Mt. Kožuf and also from mining activities in the past [56]. High contents are also determined in the river sediments of the Vardar river.

The second anthropogenic association includes $\mathrm{K}$ and $\mathrm{P}$ and it is illustrated by Factor 7 (Figure 13). The highest concentrations of $\mathrm{K}$ and $\mathrm{P}$ occur in topsoil of the Holocene alluvium and Holocene river terraces of the Crna River and wider urban area of the town of Kavadarci. Both elements are introduced into the soil because of the use of fertilizers containing $\mathrm{K}$ and $\mathrm{P}$ and are contributed to the soil where an intensive agriculture has a long tradition.

Critically high contents comparing with The New Dutch List (http://www.contaminatedland. co.uk/std-guid/dutch-l.htm) are related primarily to high concentrations of $\mathrm{Ni}$ and $\mathrm{Cr}$ that are found both in topsoil, subsoil and in the sampling points from the western part of the investigated region. Taking into account the fact that the content of these elements is higher in subsoil than in topsoil, it can be concluded that the occurrence is natural. High, sometimes critical content of $\mathrm{Cr}$ and $\mathrm{Ni}$ in the zone of Eocene flysch is already proven in numerous researches from Macedonia [62] and other Balkan countries [63-65]. The ferronickel smelter plant, in spite of the obvious environmental pollution has not contributed significantly to the measured amount of these elements, which occurs in high concentrations in the background.

High concentrations of $\mathrm{Cd}, \mathrm{Hg}, \mathrm{Pb}$ and $\mathrm{Zn}$ are also found on the SW and W, hilly part of the study area as a consequences of the high concentrations of heavy metals in organic material of topsoil or the long distance transportations, what is already shown in the experimental geochemical maps of 


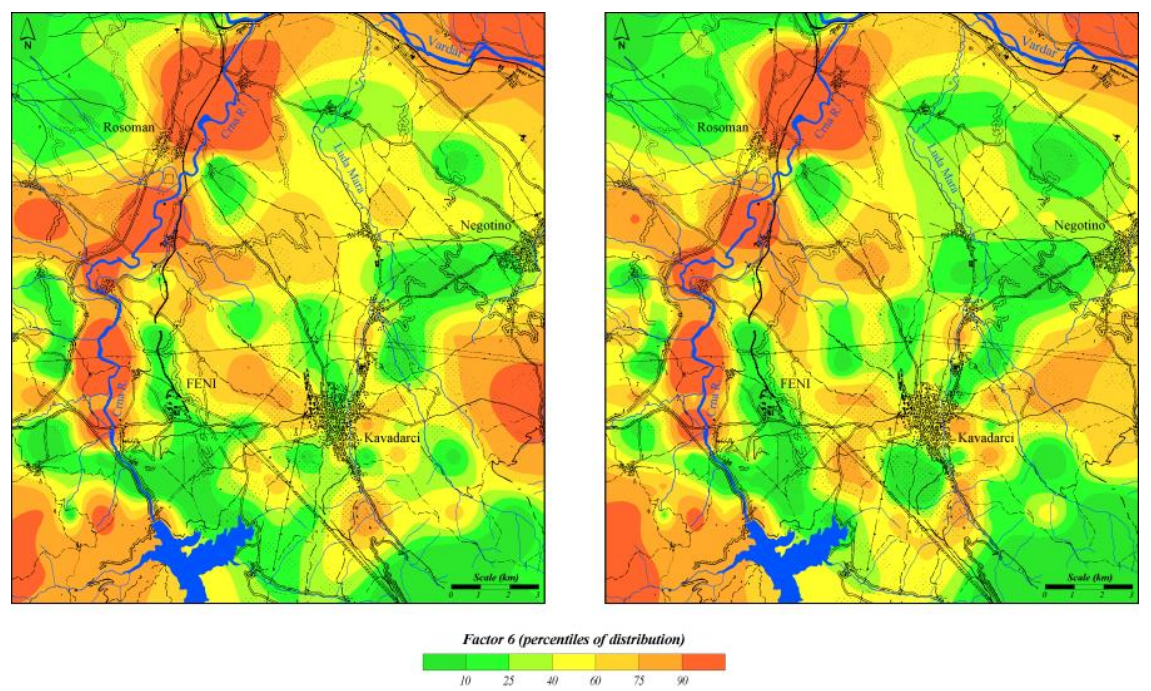

Figure 12. Distribution of Factor 6 scores (As, Sb and Tl) in topsoil (depth $0-5 \mathrm{~cm})$ and subsoil $(20-30 \mathrm{~cm})[16,43,56]$
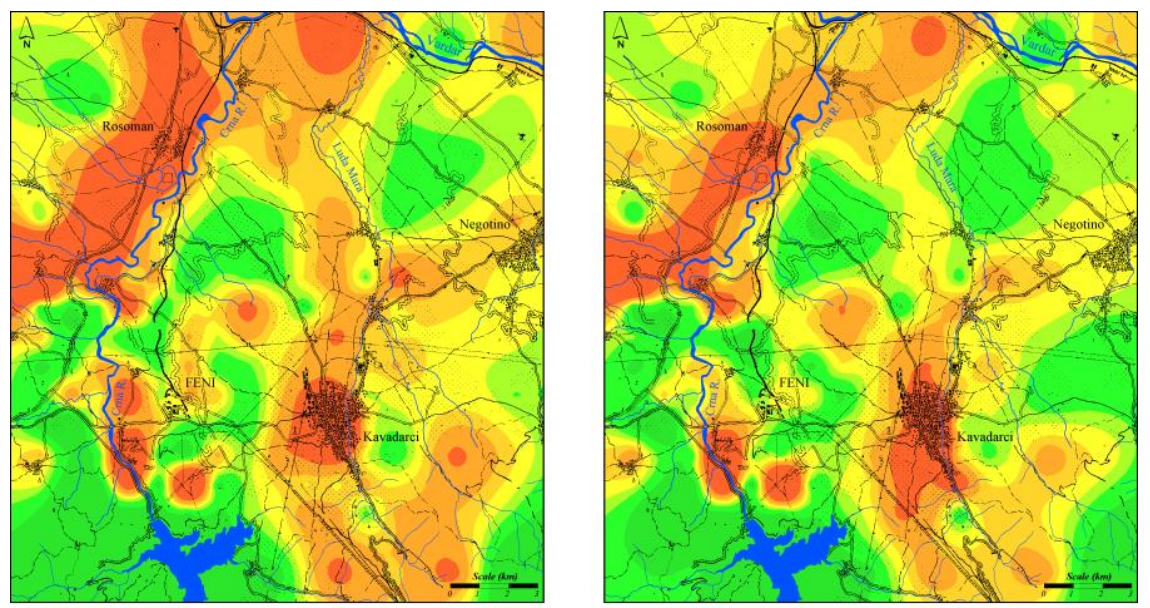

\begin{tabular}{llllll} 
Factor 7 (percentiles of distribution) \\
\hline 10 & 25 & 40 & 60 & 75 & 90
\end{tabular}

Figure 13. Distribution of Factor 7 scores (K and P) in topsoil (depth $0-5 \mathrm{~cm})$ and subsoil $(20-30 \mathrm{~cm})[16,43]$

Croatia and Slovenia [63]. High concentrations in the sampling point from the alluvium of the river of Vardar near the village of Džidimirci occur as a consequence of the lead and zinc smelter plant in Veles [15, 66] or effusing from the flotation lakes of the mines and flotation plants "Zletovo" in Probištip [67] and "Sasa" close to Makedonska Kamenica [68].

High concentrations of the heavy metals $(\mathrm{Hg}$, $\mathrm{Zn}$ ) were also found as a result of urban activities in the town of Kavadarci, but they are very low in comparison to the significantly polluted area of Veles in Macedonia [15, 66], as well as those in Slovenia [64]. It can be concluded that in regards to the distribution of $\mathrm{Cd}, \mathrm{Hg}, \mathrm{Pb}$ and $\mathrm{Zn}$, the well known Tikveš vine producing region is not a polluted area. The highest concentrations of $\mathrm{As}$, Sb and $\mathrm{Tl}$ are found on Holocene alluvium of the Crna Reka. The enrichment of the Holocene alluvium of the Crna Reka is a consequence of natural erosion from the mine deposits (As and Sb) of Allchar on Mt. Kožuf, but also from mine activities in the past [56, 67-69]. High concentrations are also determined in the river sediments of the Vardar river.

The natural enrichment is related especially to Ni. Pollution with $\mathrm{As}, \mathrm{Cd}, \mathrm{Co}, \mathrm{Cr}, \mathrm{Cu}, \mathrm{Hg}, \mathrm{Mo}$, $\mathrm{Pb}$ and $\mathrm{Zn}$ is basically insignificant. Areas with critically high concentrations of $\mathrm{Cr}$ and $\mathrm{Ni}$ cover about $5.5 \mathrm{~km}^{2}$ of topsoil $(0-5 \mathrm{~cm})$ and $5.4 \mathrm{~km}^{2}$ of subsoil $(20-30 \mathrm{~cm})$.

\section{Air pollution with heavy metals in Kavadarci region}

Due to the possible air pollution with ore dust and dust from the metallurgical process from ferronickel smelter plant situated near the town of Ka- 
vadarci, two studies were performed on air pollution with heavy metals in this region [38-40]. The purpose of these study was to establish the atmospheric deposition of various elements in this region, using moss biomonitoring $[38,40]$ and attic dust [39] and to determine whether the deposition is anthropogenic or from geogenic influences.

\section{Moss biomonitoring}

The moss sampling network includes 31 moss samples evenly distributed over a territory of about $600 \mathrm{~km}^{2}$. The moss samples were collected in 2008. A total of 46 elements (Ag, Al, As, Au, Ba, $\mathrm{Be}, \mathrm{Ca}, \mathrm{Cd}, \mathrm{Ce}, \mathrm{Co}, \mathrm{Cr}, \mathrm{Cs}, \mathrm{Cu}, \mathrm{Dy}, \mathrm{Er}, \mathrm{Eu}, \mathrm{Fe}, \mathrm{Ga}$, Gd, Ge, Hg, Ho, K, La, Li, Lu, Mg, Mn, Mo, Na, $\mathrm{Nb}, \mathrm{Ni}, \mathrm{P}, \mathrm{Pb}, \mathrm{Rb}, \mathrm{Sb}, \mathrm{Sm}, \mathrm{Sr}, \mathrm{Tb}, \mathrm{Th}, \mathrm{Ti}, \mathrm{U}, \mathrm{V}, \mathrm{Yb}$, $\mathrm{Zn}, \mathrm{Zr}$ ) were determined by mass spectrometry with inductively coupled plasma (ICP-MS). Based on a distribution pattern of elements determined in moss, two anthropogenic geochemical associations (Co-Cr-Cu-Fe-Mg-Ni and As-Cd-Cu-Hg-Pb-Zn), were detected. The distribution of these elements shows an increased content of $\mathrm{Ni}, \mathrm{Co}$ and $\mathrm{Cr}$ in the moss samples from the surroundings of the smelter plant compared to the rest of the samples (Figure 14). Thus, the median value of $\mathrm{Ni}$ in moss samples from the whole region $\left(40 \mathrm{mg} \mathrm{kg}^{-1}\right)$ is much higher than the median for Macedonia (5.82 $\mathrm{mg} \mathrm{kg}^{-1}$ ). Moreover, the median content of $\mathrm{Ni}$ in the moss samples from the polluted area (around the smelter) is $178 \mathrm{mg} \mathrm{kg}^{-1}$ with an enrichment ratio in the moss samples of almost 5.5 times higher than the unpolluted areas $\left(32 \mathrm{mg} \mathrm{kg}^{-1}\right)$. This fact confirms the influence of the dust from the ferronickel plant to the air pollution in this region.

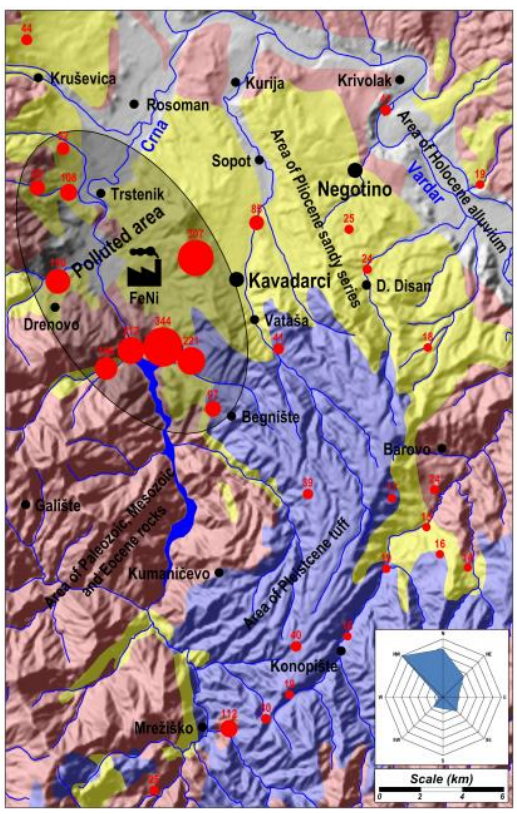

$\mathrm{Ni}$

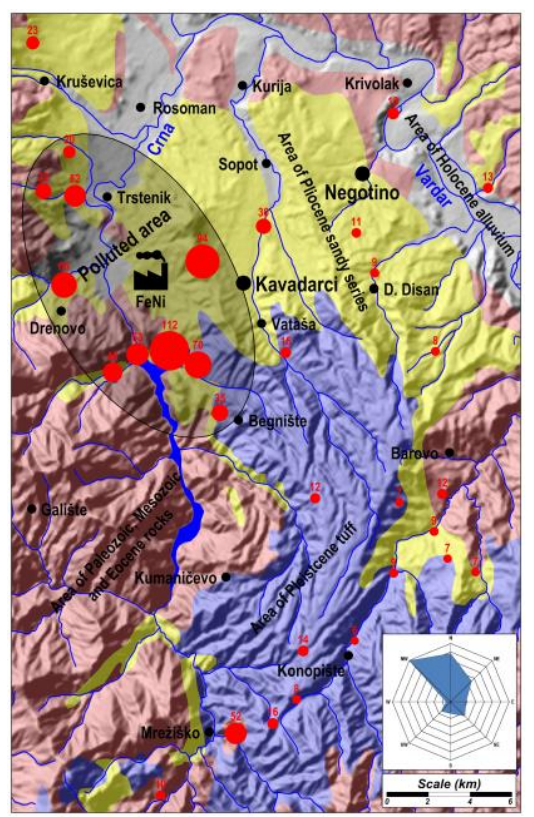

$\mathrm{Cr}$

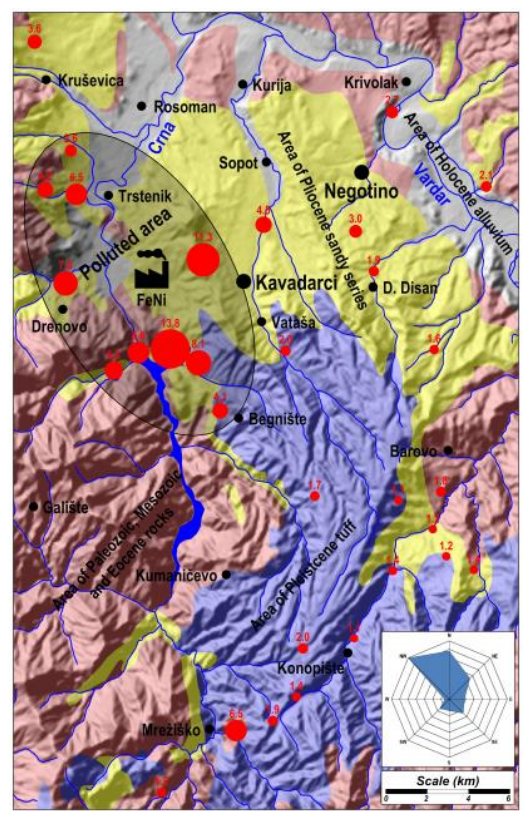

Co

Figure 14. Distribution of $\mathrm{Ni}, \mathrm{Cr}$ and $\mathrm{Co}$ in the moss samples from the Kavadarci region [40]

On the basis of the matrix of correlation coefficients, factor analysis was carried out. Principal component factor analysis was used to identify and characterize element associations [40, 70]. Three factors were identified, one geogenic (Al-Ce-Cs-Dy-Er-EuGa-Gd-Ho-La-Li-Lu-Sm-Tb-Th-Ti-V-Yb) and two anthropogenic (Ni-Co-Cr-Cu-Fe-Mg and $\mathrm{As}-\mathrm{Cd}-\mathrm{Cu}-$ $\mathrm{Hg}-\mathrm{Pb}-\mathrm{Zn}$ ) associations, interpreted as Factor 1, Factor 2 and Factor 3. The existing literature data confirms that the elements belonging to the first anthropogenic association have relatively higher contents in the iron-nickel ore used in the production of nickel in the smelter plants (between 1 and
$2.5 \% \mathrm{Ni}$, about $0.05 \% \mathrm{Co}$ and $1-3 \% \mathrm{Cr}$ ), present mainly in silicate forms. The distribution of $\mathrm{Ni}, \mathrm{Cr}$ and Co presents a specific anthropogenic marker for the Fe-Ni smelter plant operation and local air pollution. The areal distribution of these elements in the Kavadarci environment is presented in Figure 14.

\section{Attic dust air pollution with monitoring}

Continuous monitoring of the content of heavy metals and other toxic components contained in dust is possible through implementation of monitoring by using samples of dust from attic beams 
$[71,72]$. The term dust usually comprises street dust and house dust [73-76] but a particular type of house dust - the attic dust is derived predominantly from external sources such as aerosol deposits and as a result of soil dusting, and less from household activities. The attic dust as sampling material has the advantage that its composition remains constant, i.e. chemically unchanged with time. Investigations of attic dust chemistry therefore reveal the average historical state of the atmosphere [77-79]. Therefore, the study on the distribution of trace elements in attic dust samples in Kavadarci and its environs was performed to assess the size of the area eventually affected by the ferronickel smelter plant situated near the town.

Therefore, the samples of attic dust in the vicinity of Kavadarci were collected in the period of October-December 2008 at 31 sites of Kavadarci and its environs (Figure 15) [39, 80]. Close to each sample location an old house was chosen with intact attic carpentry. Although some of the selected houses were older than the ferronickel smelter plant, most of them were as old as the plant itself. To avoid collecting particles of tiles, wood and other construction materials, the attic dust samples were brushed from parts of wooden constructions that were not in immediate contact with roof tiles or floors.

A total of 46 elements (Ag, Al, As, Ba, Be, $\mathrm{Bi}, \mathrm{Ca}, \mathrm{Cd}, \mathrm{Ce}, \mathrm{Co}, \mathrm{Cr}, \mathrm{Cs}, \mathrm{Cu}, \mathrm{Dy}, \mathrm{Eu}, \mathrm{Fe}, \mathrm{Ga}, \mathrm{Gd}$, $\mathrm{Ge}$, Hf, Hg, Ho, I, K, La, Li, Lu, Mg, Mn, Mo, Na, $\mathrm{Nb}, \mathrm{Ni}, \mathrm{Pb}, \mathrm{Rb}, \mathrm{Sb}, \mathrm{Sm}, \mathrm{Sr}, \mathrm{Tb}, \mathrm{Th}, \mathrm{Ti}, \mathrm{U}, \mathrm{V}, \mathrm{Yb}$,
$\mathrm{Zn}$ and $\mathrm{Zr}$ ) were determined by mass spectrometry with inductively coupled plasma (ICP-MS).

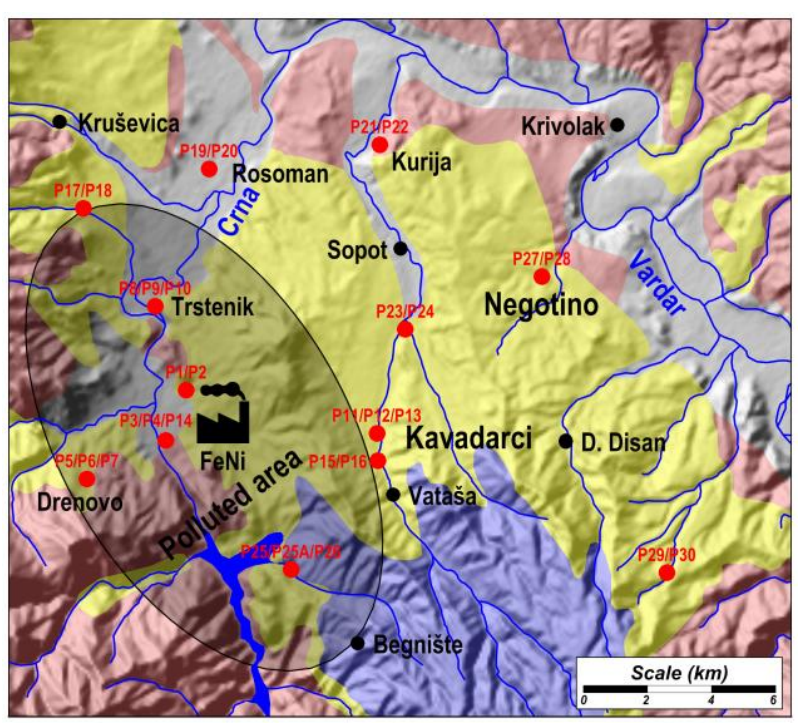

Figure 15. Location of attic dust samples in Kavadarci region [39]

The activities carried out in ferronickel ore processing and smelter plant lead to increased content of certain heavy metals $(\mathrm{Co}, \mathrm{Cr}$, Mo and $\mathrm{Ni})$ in the atmosphere especially on the houses from the villages close to the factory (Figure 16), which was determined through the conducted monitoring with attic dust samples.

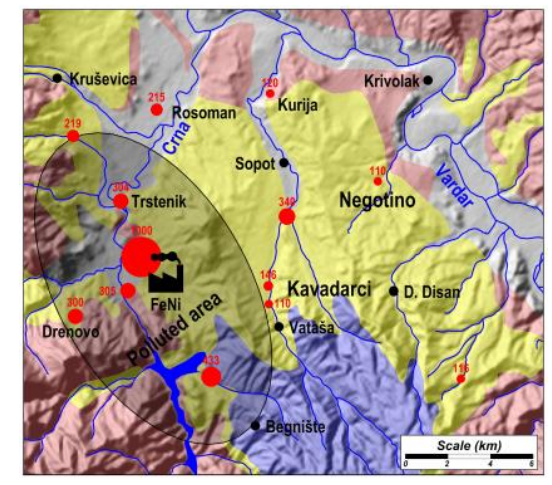

$\mathrm{Ni}$

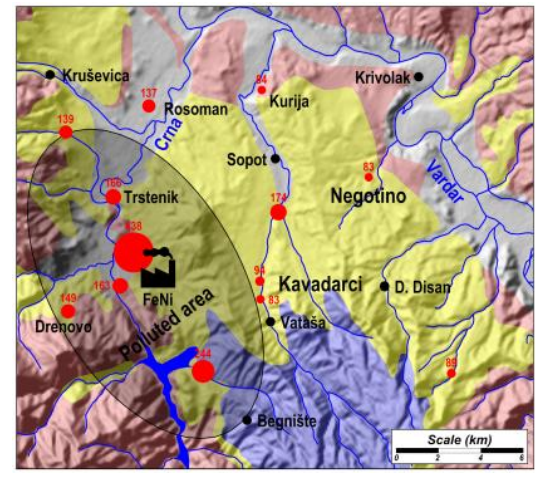

$\mathrm{Cr}$

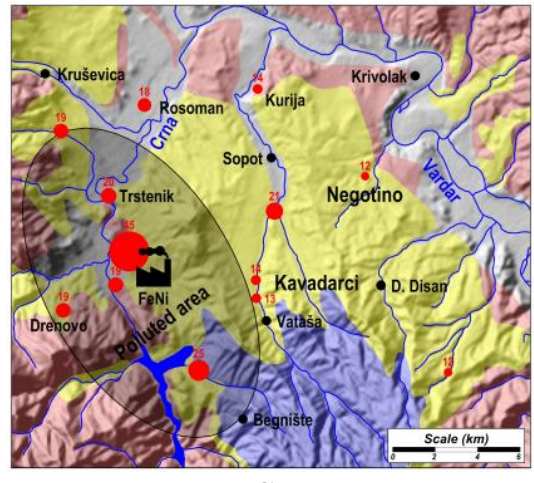

Co

Figure 16. Distribution of $\mathrm{Ni}, \mathrm{Cr}$ and $\mathrm{Co}$ in the attic dust samples from the Kavadarci region [39]

These findings were confirmed by the application of continuous probability distribution and enrichment ratio for the attic dust samples studied. It was found that the content for $\mathrm{Co}, \mathrm{Cr}$, Mo and $\mathrm{Ni}$ in attic dust samples collected around ferronickel smelter plant (polluted area) are separated by significantly higher values than those from the rest of the samples of the investigated region (Table 1).
Samples that are around the ferronickel smelter plant are characterized by the highest contents of those elements. Thus, the average value for the content of nickel in attic dust samples from the polluted area is $354 \mathrm{mg} \mathrm{kg}^{-1}$ and from the unpolluted area is $156 \mathrm{mg} \mathrm{kg}^{-1}$, having an enrichment ratio of 2.27 . However, the range of values shows a high content of nickel in the samples taken from the vicinity of 
the ferronickel smelter plant that ranges from 89 to $1200 \mathrm{mg} \mathrm{kg}^{-1}$ (Figure 16). Cobalt and chromium results show significantly higher contents in the samples of attic dust taken from the Kavadarci area, as well (Figure 16). The median value for Co in attic dust samples taken from the studied area is 17 $\mathrm{mg} \mathrm{kg}$ (ranges from 10 to $52 \mathrm{mg} \mathrm{kg}^{-1}$ ), and the median value for $\mathrm{Cr}$ is $140 \mathrm{mg} \mathrm{kg}^{-1}$ (ranges from 72 to $510 \mathrm{mg} \mathrm{kg}^{-1}$ ). For the remaining elements there are no such significant distortions in the distribution of values.

These findings were confirmed also by the application of continuous probability distribution and enrichment ratio for the attic dust samples stud- ied (Table 1). According to the sampling locations, attic dust samples from the polluted areas around the ferronickel smelter plant (14 samples) are compared with corresponding data with the rest of the samples of the investigated region (unpolluted area, 17 samples). Based on the obtained data it can be seen that the averages for samples that are around ferronickel smelter plant (polluted area) for $\mathrm{Co}, \mathrm{Cr}$ and $\mathrm{Ni}$ are separated by significantly higher contents, in the values for averages in the rest (unpolluted area) of the samples of the investigated region. Samples around the ferronickel smelter plant are characterized by the highest contents of those elements.

Table 1. Averages and enrichment ratios (ER) of $\mathrm{Co}, \mathrm{Cr}$ and $\mathrm{Ni}$ in attic dust samples from Kavadarci region and from the ferronickel smelter plant area [39]

\begin{tabular}{cccccc}
\hline Element & $\begin{array}{c}\text { Average for Ka- } \\
\text { vadarci region }\end{array}$ & $\begin{array}{c}\text { Samples around } \\
\text { the Fe-Ni smelter }\end{array}$ & $\begin{array}{c}\text { Samples from the } \\
\text { rest of the region }\end{array}$ & $\begin{array}{c}\text { ER } \\
\text { (Feni/Rest) }\end{array}$ & $\begin{array}{c}\text { F (around Feni } \\
\text { smelter) }\end{array}$ \\
\hline $\mathrm{Co}$ & 18 & 22 & 15 & 1.50 & 12.86 \\
$\mathrm{Cr}$ & 140 & 193 & 105 & 1.84 & 18.67 \\
$\mathrm{Ni}$ & 230 & 354 & 156 & 2.27 & 17.90 \\
\hline
\end{tabular}

ER - enrichment ratios (polluted area vs. unpolluted area); $\mathrm{F}$ - continuous probability distribution (analysis of variance) for attic dust between polluted area and unpolluted area, significant values $(p=0.05)$

\section{Monitoring of air pollution by deposited dust}

Deposited matter refers to any dust that falls out of suspension in the atmosphere. Solid and liquid particles or dust that falls out of suspension in the atmosphere can get into the environment and lead to its contamination [80, 81]. Atmospheric total deposition (deposited dust) is very useful mechanism for monitoring the fate of anthropogenic elements introduced into the atmosphere [82]. Fine powder with a high content of heavy metals is generated as a result of emissions from the processing of ores and metallurgical process and is distributed as a result of the wind blowing. Many investigations have focused on the chemical composition and the content of toxic substances in deposited matter [83-85].

In order to determine daily amount of fine dust contained in the air in the area of Kavadarci (including the area of ferronickel smelter plant), during 2009 the samples of total deposited dust were collected at three locations (hot spots in the area), where it could be expected large amounts of deposited dust, the Vozarci and Brušani villages and town of Kavadarci (Figure 17). The total quantity of the deposited dust was monitored monthly for a period of one year. Data is usually collected over monthly periods and results are expressed $\mathrm{mg} \mathrm{m}^{-2} \mathrm{~d}^{-1}$ (i.e. the mass of dust deposited per $\mathrm{m}^{2}$ per day). This method enables determination of the relative 'dustiness' of sampling locations.

From the obtained data it can be seen that the median values for $\mathrm{Ni}$ in deposited dust samples taken from the studied area is $101 \mathrm{mg} \mathrm{kg}^{-1}$ and the $\mathrm{min} / \mathrm{max}$ range of values shows much higher content of this element in the samples from this area (ranges from 5.24 to $1289 \mathrm{mg} \mathrm{kg}^{-1}$ ). Similar results are obtained for the distribution of $\mathrm{Co}$ and $\mathrm{Cr}$, thereby the median value and the $\mathrm{min} / \mathrm{max}$ range for these elements indicate increased content of these elements. The median value for $\mathrm{Cr}$ in deposited dust samples taken from the studied area is $11.96 \mathrm{mg} \mathrm{kg}^{-1}$ (ranges from 0.73 to $139 \mathrm{mg} \mathrm{kg}^{-1}$ ), and for Co the median value in deposited dust samples taken from the studied area is $3.91 \mathrm{mg} \mathrm{kg}^{-1}$ (ranges from 0.23 to $75.58 \mathrm{mg} \mathrm{kg}^{-1}$ ). The amount of total deposited dust that is spread in the air is presented in Figure 18. From the results obtained in this investigation it is evident that a large amount of deposited dust were recorded in summer in 2009 when the values were close to or above the maximum permitted amount of dust powder $\left(300 \mathrm{mg} \mathrm{m}^{-2} \mathrm{~d}^{-1}\right)$.

On the bases of the amounts of dust and its content it can be also concluded that the ferronickel smelter plant affects on the distribution of large amounts of dust in its environ trough the whole year. From the results obtained it is clear that a large amount of deposited dust were recorded in summer 
when the values were close to or above the maximum amount of dust powder $\left(300 \mathrm{mg} \mathrm{m}^{-2} \mathrm{~d}^{-1}\right)$. The values for the content of nickel in deposited dust collected in the village of Vozarci (near smelter plant) in the winter period is very high while in the remaining period of its content is relatively low (max. content $1290 \mathrm{mg} \mathrm{kg}{ }^{-1}$ ). This trend of increased content of nickel in the dust monitor is followed by the content of chromium and cobalt in deposited dust.

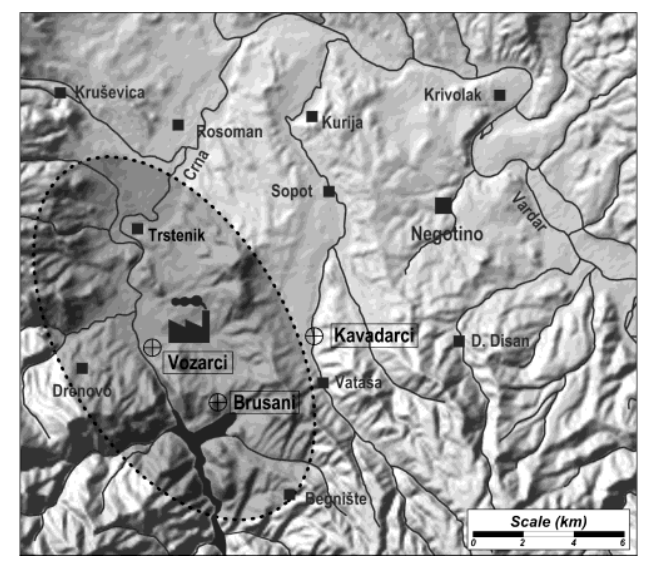

Figure 17. Location of the sampling points for deposited dust for the Kavadarci region [81]

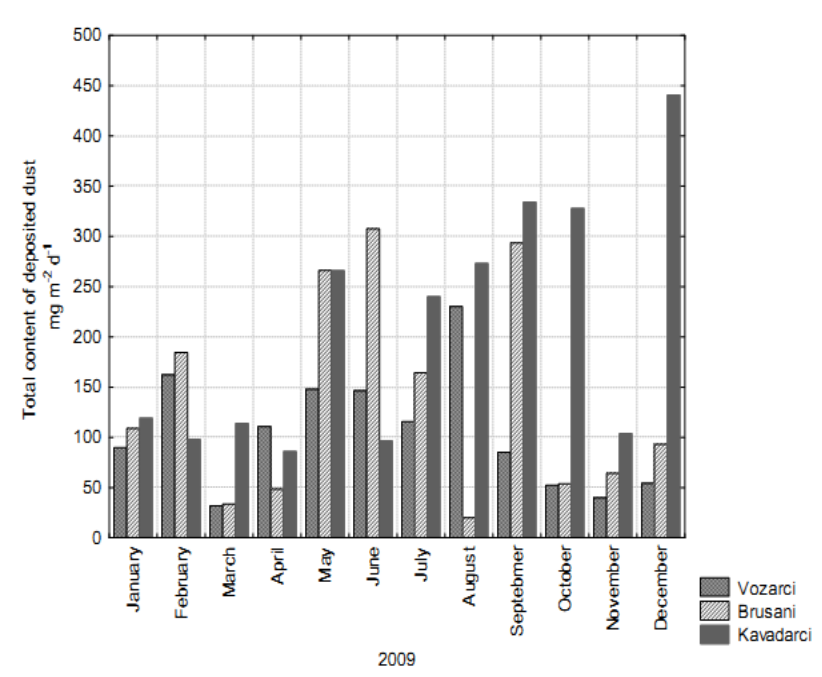

Figure 18. The total content of deposited dust in Kavadarci region [81]

\section{RADOVIŠ REGION (COPPER MINE AND FLOTATION)}

One of the major emission sources of certain metals in the eastern part of the Republic of Macedonia is the copper mine and flotation Bučim, near the town of Radovišs. The Bučim copper mine and flotation plant is located in the eastern part of the
Republic of Macedonia. The studied area includes wide region of the town of Radoviš with a surface area of $20 \mathrm{~km}(\mathrm{~W}-\mathrm{E}) \times 20 \mathrm{~km}(\mathrm{~S}-\mathrm{N})$, a total of 400 $\mathrm{km}^{2}$, limited by the coordinates N: $41^{\circ} 32^{\prime}-41^{\circ} 44^{\prime}$ and E: $22^{\circ} 15^{\prime}-22^{\circ} 30^{\prime}$ (Figure 19). The region is characterized by a moderate continental climate [50]. The altitude varies between 350 and $1000 \mathrm{~m}$. The average annual temperature is around $10{ }^{\circ} \mathrm{C}$. The average annual rainfall amount is $563 \mathrm{~mm}$ with large variations from year to year. The most frequent winds in the region are those from the west and east.

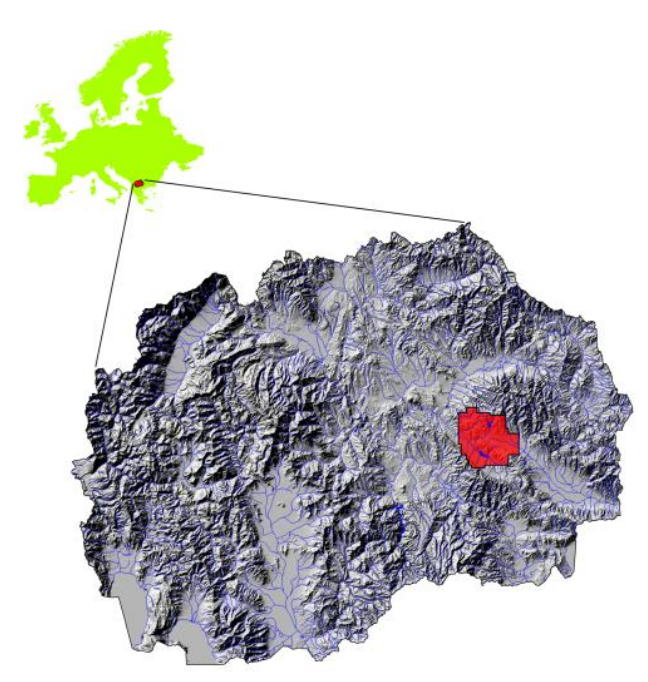

Figure 19. Radoviš study area [86]

The Bučim copper mine and ore processing plant have been in function from the late seventies of the last century. Ore excavation is from an open pit and the ore tailings are stored on the open, in the mine vicinity. The produced copper ore from the mine is processed in the flotation plant; after the flotation of copper minerals, the flotation tailings are separated, disposed of and deposited on a dump site in an adjacent valley near the village of Topolnica. The Bučim copper mine is located in the northwest part of the studied area. The Bučim mine territorially and administratively belongs to the municipality of Radoviš, and is located about $14 \mathrm{~km}$ from the town. Mine activities cover $7 \mathrm{~km}^{2}$ of total mine surfaces, 4 $\mathrm{km}^{2}$ for the placement of ore tailings and the rest belongs to the open ore pit and ore processing plant. The main ore contents are the following: $0.3 \% \mathrm{Cu}$. The important metallic minerals found are chalcopyrite, pyrite, and bornite, with small amounts of galena, sphalerite, magnetite and hematite [86].

The Bučim mine and the ore processing plant have been operating since 1979 and it is assumed that the mine has about 40 million tons of ore reserves. Ore tailings are dropped out by the dampers from the open ore pit at an open site near the mine. 
The ore tailings deposit occupies a surface of 0.80 $\mathrm{km}^{2}$, located southwest of the open ore pit, near the regional road Štip-Strumica. The ore tailings deposit contains about 150 million tons of ore tailings. Exposure of ore tailings to constant air flow and wind leads to distribution of fine dust in the air [86]. The flotation plant produces 4 million tons of copper ore annually. In the process of flotation of copper minerals, the average annual amount of produced flotation tailings is approximately 3.95 million tons. These tailings are drained and disposed of on a dump near the mine. The dump is located to the east of the flotation plant, at a distance of about $2.2 \mathrm{~km}$.

The copper ore and ore tailings continually are exposed to open air, so that it occurs winds to carry out the fine particles into atmosphere. Therefore, a study on soil [87] and air pollution [88-93] in this area was implemented. Biomonitoring with moss [70, 88, 89, 93] and lichens [92, 93], as well as attic dust samples $[80,90]$ and samples from total deposited matter [91], were used for monitoring the possible atmospheric pollution with copper in mine vicinity.

\section{Soil pollution with heavy metals in the vicinity of Bučim mine}

In order of assess the potential health risks, the study focuses on the monitoring of distribution and characterization of metals and some lithogenic elements in soil in the Bučim mine copper environ [90]. For this study a total of 40 soils were collected using a previously adapted sampling network (5 $\times 5 \mathrm{~km}^{2}$ ). Two soil samples were taken in 2008 at each location: a sample from the surface layer of soil - topsoil $(0-5 \mathrm{~cm})$ and a deep soil layer - subsoil $(20-30 \mathrm{~cm})$. Characterization was conducted on the basis of on 18 elements: $\mathrm{Al}, \mathrm{As}, \mathrm{Ba}, \mathrm{Ca}, \mathrm{Cr}$,
$\mathrm{Cu}, \mathrm{Ga}, \mathrm{Li}, \mathrm{Fe}, \mathrm{K}, \mathrm{Mg}, \mathrm{Mn}, \mathrm{Na}, \mathrm{Ni}, \mathrm{Pb}, \mathrm{Sr}, \mathrm{V}$ and $\mathrm{Zn}$. From descriptive statistics, median values for all elements were obtained. Relatively small median for $\mathrm{Cu}\left(23 \mathrm{mg} \mathrm{kg}^{-1}\right)$ was not expected in this area, because of the influence from the copper mine. However, the range of values shows much higher content of this element in the samples from the study area $\left(9.3-1200 \mathrm{mg} \mathrm{kg}^{-1}\right)$. The enrichment factor of TS/SS for $\mathrm{Cu}$ was 2.8 for the whole study area and $\sim 10$ for close mine environ. This is because of large amount of continuous and uncontrolled distribution of fine dust from ore waste and flotation tailings surface. Wind distribution of copper high contented dust follows the wind rose for the region. For the rest of the potentially anthropogenic elements $(\mathrm{Pb}, \mathrm{Ni}, \mathrm{V}$ and $\mathrm{Zn}$ ), no significant enrichment factors were found. The lithogenic elements ( $\mathrm{Al}, \mathrm{As}, \mathrm{Cr}, \mathrm{Ga}, \mathrm{Fe}$, $\mathrm{Li}, \mathrm{Mg}, \mathrm{Mn}, \mathrm{Na}, \mathrm{Ni}, \mathrm{Sr}$ ) content showed stability in the vertical direction (TS/SS); but in an across direction varied according to the geology of the region (as explained by factor distribution).

Variability in the elements contents was determined considering the type of land use. The median value for copper in cultivated area was $26 \mathrm{mg} \mathrm{kg}^{-1}$, in the uncultivated area was $25 \mathrm{mg} \mathrm{kg}^{-1}$, in the urban area was $22 \mathrm{mg} \mathrm{kg}^{-1}$ and in the mine environs was $19.3 \mathrm{mg} \mathrm{kg}^{-1}$. Because of the wide range values of the copper content in mine environs, the average amount was although considered $\left(190 \mathrm{mg} \mathrm{kg}^{-1}\right)$. Compared with average amount of $\mathrm{Cu}$ in World soils $30 \mathrm{mg} \mathrm{kg}^{-1}$ and European soils $17 \mathrm{mg} \mathrm{kg}^{-1}$ [45], it can be classified as a significantly contaminated area.

For these elements, comparative analysis was conducted in order to test the variability of the TS/SS relation, and it was found that only $\mathrm{Cu}$ contents vary with respect to their TS/SS relation, due most probably to anthropogenic mine impact (Figure 20).

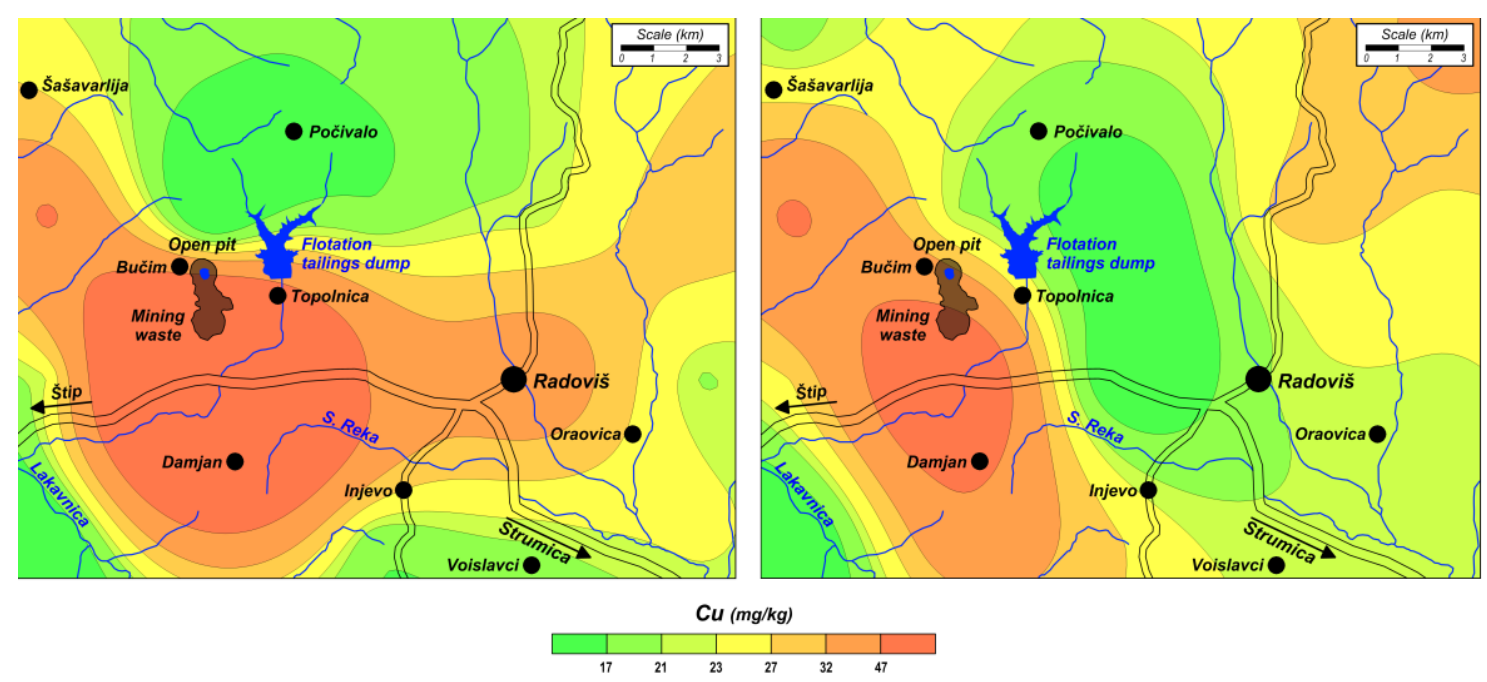

Figure 20. Spatial distribution of $\mathrm{Cu}$ in topsoil (left) and subsoil (right) [90] 


\section{Moss biomonitoring}

Total of 52 moss samples including Hypnum cupressiforme as dominant species (72\%), Camptothecium lutescens $(22 \%)$, were used for biomonitoring of possible atmospheric pollution with heavy metals in the vicinity of copper mine and flotation plant "Bučim" near the town of Radoviš $[88,89]$. A total of 16 elements (Al, As, Ba, Ca, Cd, Co, Cr, $\mathrm{Cu}, \mathrm{Fe}, \mathrm{K}, \mathrm{Mn}, \mathrm{Na}, \mathrm{Ni}, \mathrm{Pb}, \mathrm{Sr}$, and $\mathrm{Zn}$ ) were analyzed by application of atomic emission spectrometry with inductively coupled plasma (ICP-AES) and atomic absorption spectrometry (AAS). The de- scriptive statistics of the analyzed elements is shown in Table 2.

On the basis of normality tests compared with histograms of distribution of the content of all analyzed elements in moss, normality was assumed for natural values only for $\mathrm{Ba}$; for the rest of the elements, normality was established on the basis of the logarithms of their contents. Lithogenic elements (Al, As, Cr, Fe, Mn, Ni) deposit in the environment corresponding to the geology of the region, and natural enrichment was not assumed.

Table 2. Descriptive statistic of measurements for moss samples (values of $\mathrm{Al}, \mathrm{Ca}, \mathrm{Fe}$, and $\mathrm{K}$ are given in \% and the remaining elements in $\mathrm{mg} \mathrm{kg}^{-1}$ ) [89]

\begin{tabular}{ccccccccccc}
\hline & $n$ & $\mathrm{Dis}$ & $\mathrm{X}_{\mathrm{a}}$ & $\mathrm{X}_{\mathrm{g}}$ & $\mathrm{Md}$ & $\min$ & $\max$ & $\mathrm{Var}$ & $s$ & $\mathrm{CV}$ \\
\hline $\mathrm{Al}$ & 52 & $\log$ & 2.12 & 1.83 & 1.72 & 0.47 & 8.51 & 1.77 & 1.33 & 62.8 \\
$\mathrm{As}$ & 52 & $\log$ & 2.62 & 1.54 & 1.55 & 0.14 & 13.7 & 9.36 & 3.06 & 117 \\
$\mathrm{Ba}$ & 52 & $\mathrm{~N}$ & 32.4 & 29.7 & 30.6 & 11.5 & 66.0 & 166 & 12.9 & 39.7 \\
$\mathrm{Ca}$ & 52 & $\log$ & 6.43 & 6.30 & 6.24 & 4.53 & 10.6 & 1.87 & 1.37 & 21.3 \\
$\mathrm{Cd}$ & 52 & $\log$ & 0.54 & 0.48 & 0.49 & 0.18 & 1.75 & 0.08 & 0.28 & 51.2 \\
$\mathrm{Co}$ & 52 & $\log$ & 1.09 & 0.72 & 0.70 & 0.12 & 7.60 & 1.94 & 1.39 & 128 \\
$\mathrm{Cr}$ & 52 & $\log$ & 3.14 & 2.70 & 2.63 & 1.00 & 10.8 & 4.41 & 2.10 & 66.8 \\
$\mathrm{Cu}$ & 52 & $\log$ & 20.7 & 11.5 & 9.95 & 2.14 & 199 & 1141 & 33.8 & 163 \\
$\mathrm{Fe}$ & 52 & $\log$ & 3.29 & 2.85 & 2.63 & 0.74 & 12.4 & 3.86 & 1.96 & 59.7 \\
$\mathrm{~K}$ & 52 & $\log$ & 3.22 & 3.17 & 3.16 & 1.93 & 4.51 & 0.30 & 0.54 & 16.9 \\
$\mathrm{Mn}$ & 52 & $\log$ & 165 & 153 & 144 & 59.0 & 439 & 4888 & 69.9 & 42.3 \\
$\mathrm{Na}$ & 52 & $\log$ & 46.3 & 44.6 & 45.8 & 25.1 & 81.5 & 164 & 12.8 & 27.6 \\
$\mathrm{Ni}$ & 52 & $\log$ & 7.37 & 6.53 & 6.21 & 2.10 & 30.1 & 21.0 & 4.58 & 62.1 \\
$\mathrm{~Pb}$ & 52 & $\log$ & 8.82 & 7.36 & 6.81 & 2.68 & 40.2 & 46.1 & 6.79 & 76.9 \\
$\mathrm{Sr}$ & 52 & $\log$ & 26.1 & 24.7 & 24.1 & 12.9 & 55.4 & 83.0 & 9.11 & 34.9 \\
$\mathrm{Zn}$ & 52 & $\log$ & 29.2 & 28.4 & 28.3 & 17.3 & 53.7 & 46.5 & 6.82 & 23.4 \\
\hline
\end{tabular}

Dis - distribution (log - lognormal; $\mathrm{N}$ - normal); $\mathrm{X}_{\mathrm{a}}$ - arithmetic mean; $\mathrm{X}_{\mathrm{g}}$ - geometric mean;

Md - median; min - minimum; max - maximum; Var - variance; $s$ - standard deviation; CV - coefficient of variance.

On the basis of the matrix of correlation coefficients, factor analysis was performed. The factor analysis was performed to identify and characterize element associations. Three factors were identified, one anthropogenic and 2 geogenic, interpreted as Factor 1, Factor 2 and Factor 3, which cover $90 \%$ of variability of treated elements.

Factor 1 (Al-As-Cd-Cu-Fe-Pb-Zn) associates chemical elements that indicate anthropogenic influence in the study area (Figure 21a). This association of elements was expected because of the geology of the study area and the works related to open ore pit and flotation activities. The acid drainage rapidly dissolved the elements, providing increased content in the soil. The open ore pit and flotation tailings dam allow direct exposure of the finest ore particles to the atmosphere. Corpuscle dust from the surface layer of the ore body and soil is spread in the atmosphere by the winds, in which way the atmospheric distribution of these elements in the vicinity of the mine is performed. Increasing content of these anthropogenic elements in moss samples in close vicinity of mine, precisely near Bučim and Topolnica villages, assumed as most polluted settlements, from aspect of human health's risk. Maximum values for the content of $\mathrm{Al}, \mathrm{As}, \mathrm{Cd}, \mathrm{Cu}$, $\mathrm{Fe}, \mathrm{Pb}$ and $\mathrm{Zn}$ are obtained from moss samples close to village of Bučim (Figure 21).

Factor $2(\mathrm{Cr}-\mathrm{Ni}-\mathrm{Sr})$ presents a typical geogenic factor. These elements are biogenic trace elements and are essential for the moss tissue. High factor loadings are related to the parts of Pleisto- 
cene sediments and Neogene dacites, andesites and pyroclastites. The correlation of $\mathrm{Cr}-\mathrm{Ni}$ mostly relies on their geological occurrence in the study area. However, the $\mathrm{Sr}$ content correlation in this association also relies on certain natural phenomena.

The elements with the Factor 3 (Ba-K-Na) are naturally found in soil and moss as macro-elements [89]. The contents of these elements are variable and are not related to any anthropogenic activ- ities. Their sources are mainly natural phenomena such as rock weathering and chemical processes in soil. This Factor is connected to the clay which is a product of disintegration mostly of feldspar and gneisses and micaschists. This means that the occurrence of this Factor is typical for the oldest formations in the Republic of Macedonia (Proterozoic micaschist and Proterozoic gneisses).

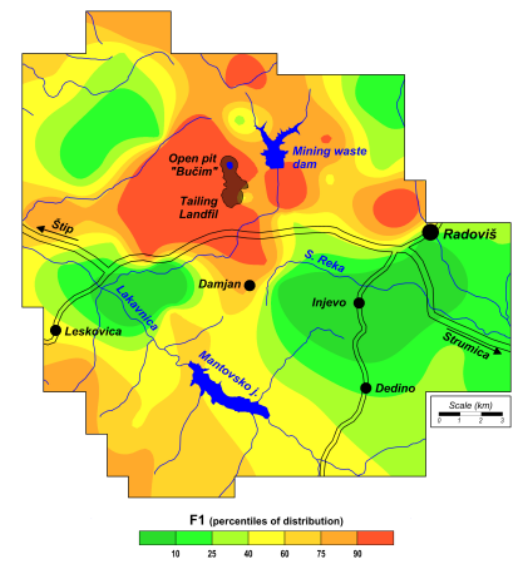

(a)

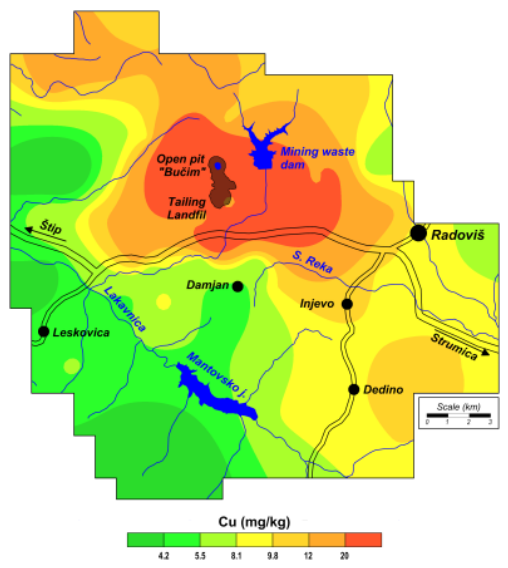

(b)

Figure 21. Spatial distribution of Factor 1 scores ( $\mathrm{Al}, \mathrm{As}, \mathrm{Cd}, \mathrm{Cu}, \mathrm{Fe}, \mathrm{Pb}$ and $\mathrm{Zn}$ ) (a) and spatial distribution of copper (b) [89]

\section{Biomonitoring with lichens}

Lichen biomonitoring has proved to be a very useful technique for determining the atmospheric deposition of heavy metals in potentially polluted areas [94]. Based on physical, chemical and biological properties, lichens are used as monitors of metal deposition from the atmosphere, since they can accumulate trace elements to levels far greater than their expected physiological needs $[95,96]$.

For that reason, lichen species (Hypogymnia physodes and Evernia prunastri) were also used for biomonitoring of atmospheric pollution with heavy metals due to copper mining activities near the mine using lichens collected in the vicinity of Bučim copper mines [92, 93]. For this purpose, fifty samples of lichen species Hypogymnia physodes (Nyl.) and Evernia prunastri (Ach.) were collected in 2008 from the whole study area (Figure 22). These lichen species are characteristic of the flora of the Republic of Macedonia and can be used as bioindicators. Depending on the conditions and the accessibility of the locations, the lichen species that were available and typical for the region were collected.

Multivariate statistical methods (cluster and R-mode factor analyses) were used to reveal the associations of the chemical elements. Three geogenic (F1, F2, F3) and one anthropogenic (F4) associations were established on the basis of: visually indicated similarity of spatial distribution of elemental patterns; correlation coefficient matrix, and results of cluster and factor analyses.

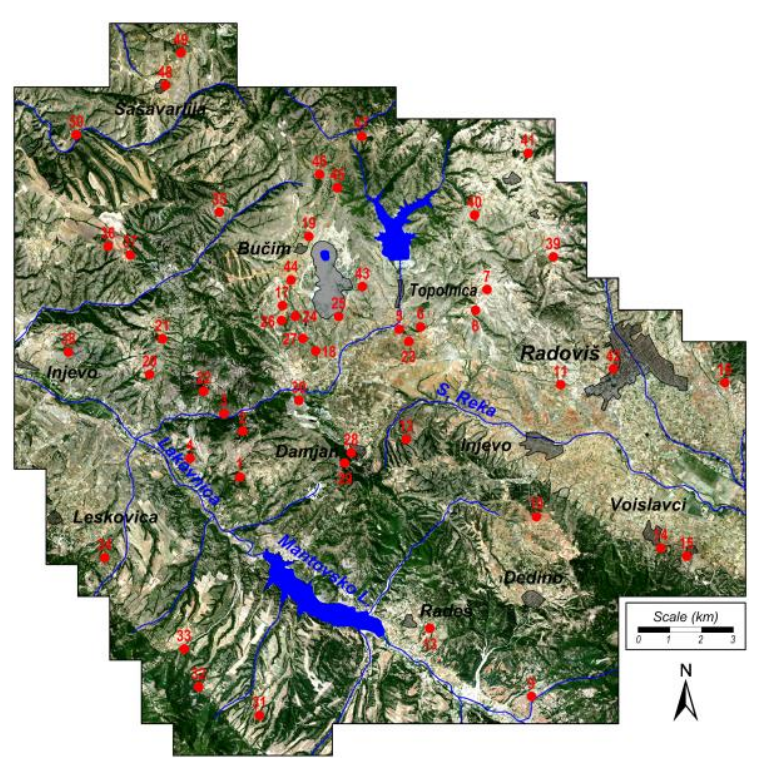

Figure 22. Lichen sample locations [92] 
Factor 1, the first geogenic association (Al, $\mathrm{Cr}, \mathrm{Fe}, \mathrm{Li}$ and $\mathrm{V}$ ), consists of elements which are only slightly affected by anthropogenic activities. Group characteristics are high values of correlation coefficients between chemical elements within the sampled media. Their sources are mainly natural phenomena, such as rock weathering and soil surface dusting. In addition, the areal distribution of mentioned elements is closely dependent on the lithology. The spatial distribution of these elements is due to the presence of clay, which is the product of disintegration of primary rocks. The areal distribution of these elements in the two sampling materials is very similar.

Factor 2 associates $\mathrm{Ca}, \mathrm{Cd}, \mathrm{K}$ and $\mathrm{Zn}$, and represents the group of geochemical association which contains biogenic elements and essential trace elements in lichen plant tissue (except $\mathrm{Cd}$ ). On the other hand, high values of factor loadings are probably related to the geology of the study area, with remnants of Pleistocene unconsolidated sediments. Higher contents, especially of $\mathrm{Cd}$ and $\mathrm{Zn}$, were present in the higher elevation sites.

Factor 3 presents the third naturally association of elements, consisting of $\mathrm{Ni}$ and $\mathrm{Sr}$. This association is naturally found in the living environment. Their origin is mainly due to certain natural phenomena and the geology of the ground. The highest content of these elements is found in the area of Neogene dacites, andesites and pyroclastites and residues from Proterozoic micashist.

Factor 4 demonstrates a geochemical anomaly caused by the $\mathrm{Cu}$ mining. The group comprises $\mathrm{Cu}$ and $\mathrm{Pb}$, elements that were introduced into the environment through anthropogenic activities (Figure 23). Appearance of this anthropogenic factor was expected because of the presence of copper open pits. These elements usually appear in higher content due to mining activities [97]. Fine dust fractions are easily emitted from the open ore pit and minerals. The exposure of mine and flotation tailings in the open, under the continuous influence of the erosive effects of winds and moisture, allows distribution of the finest particles from the surface. Fine dust with a higher content of these elements is constantly carried by the winds and so distributed in the air and spread to larger distances away from the mine. The spatial distribution of this factor (Figure 23) clearly shows that high contents of these elements are found in close vicinity of the mine. Distant areas are not affected by higher values of their contents.

The lichen samples, taken from the close vicinity of the mine, show high values for the content of copper and other anthropogenic elements. The median value of copper is not a worrying aspect $\left(6.8 \mathrm{mg} \mathrm{kg}^{-1}\right)$, but the median value of samples of lichen collected in the vicinity of the mine, is showing a significantly higher value of approximately 25 $\mathrm{mg} \mathrm{kg}^{-1}$ (increased by a factor of 4 times). The highest value for copper $\left(130 \mathrm{mg} \mathrm{kg}^{-1}\right)$ was obtained from a lichen sample collected very close to the mine. Lead shows a strong correlation with copper content $(r=0.93)$, with a low median value (4.2 $\mathrm{mg} \mathrm{kg}^{-1}$ ), but very high median value from lichen samples in close vicinity to the mine $(20 \mathrm{mg}$ $\mathrm{kg}^{-1}$ ), increased by a factor of 5 times) and maximum value of $120 \mathrm{mg} \mathrm{kg}^{-1}$.

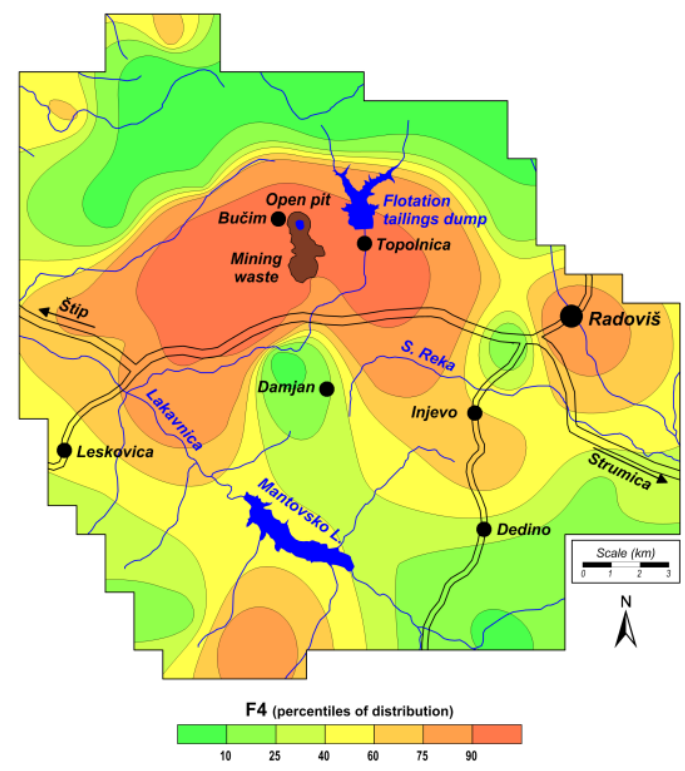

Figure 23. Spatial distribution of Factor 4 scores $(\mathrm{Cu}$ and $\mathrm{Pb})$ [92]

The comparison of the median and range values for the anthropogenic elements obtained from lichen samples with the corresponding values obtained from moss samples (species: Hyloconium splendens and Pleurozium schrebery), collected from the same study area [91], is presented in Table 3 [94]. The values for the contents of both elements is highly similar $(r=0.86$ and $r=0.68)$, which of course is due to similar modes of accumulation and binding of these elements in mosses and lichen plant tissues. On the other hand, lichen showed a strong tolerance to high contents of these heavy metals $(>0.01 \%)$. However, the ultimate effect is that lichen species (Hypogymnia physodes and Evernia prunastri) reflect the real atmospheric distribution, not only for the anthropogenic elements, but also for those elements that are little affected by anthropogenic activities from the copper mine (Al, $\mathrm{Ca}, \mathrm{Cd}, \mathrm{Cr}, \mathrm{Fe}, \mathrm{Li}, \mathrm{K}, \mathrm{Ni}, \mathrm{Sr}, \mathrm{Zn}$ and $\mathrm{V}$ ). 
Table 3. Comparative analyses of median and range values between moss and lichen element content

\begin{tabular}{lccccc}
\hline \multirow{2}{*}{ Element } & \multicolumn{2}{c}{ Lichen samples (Present study) } & \multicolumn{2}{c}{ Moss samples [89] } & \multirow{2}{c}{$\begin{array}{c}\text { Correlation } \\
\text { coefficients } \\
\text { moss : lichen }\end{array}$} \\
\cline { 2 - 5 } & Median & Range & Median & Range & $2.1-198$ \\
$\mathrm{Cu}$ & 6.84 & $1.50-130$ & 10 & 0.86 \\
$\mathrm{~Pb}$ & 4.20 & $0.61-120$ & 6.8 & $2.7-40.2$ & 0.68 \\
\hline
\end{tabular}

\section{Air pollution study in the Bucim mine area with attic dust}

A total of 62 attic dust samples were collected in 2008 from the attics of 29 houses, built between 1920 and 1970 in the vicinity of copper mining Bučim near Radoviš. Sixteen elements ( $\mathrm{Al}, \mathrm{As}$, $\mathrm{Ba}, \mathrm{Ca}, \mathrm{Cd}, \mathrm{Co}, \mathrm{Cr}, \mathrm{Cu}, \mathrm{Fe}, \mathrm{K}, \mathrm{Mn}, \mathrm{Na}, \mathrm{Ni}, \mathrm{Pb}, \mathrm{Sr}$, and $\mathrm{Zn}$ ) were analyzed by atomic emission spectrometry with inductively coupled plasma (ICPAES). The obtained values of the investigated elements in attic dust samples were statistically processed using nonparametric and parametric analysis. Factor analysis revealed three factors governing the source of individual chemical elements. Two of them grouping $\mathrm{Ca}, \mathrm{Li}, \mathrm{Mg}, \mathrm{Mn}$ and $\mathrm{Sr}$ (Factor 1) and $\mathrm{Co}, \mathrm{Cr}$ and $\mathrm{Ni}$ (Factor 2) can be characterized as geogenic. The third factor grouping $\mathrm{As}, \mathrm{Cd}, \mathrm{Cu}$ and $\mathrm{Pb}$ is anthropogenic and mirrors dust fallout from mining operation and from flotation tailings. Maps of areal deposition were prepared for this group of elements, wherefrom correlation of these anthropogenic born elements was confirmed.

Factor $1(\mathrm{Ca}, \mathrm{Li}, \mathrm{Mg}, \mathrm{Mn}$ and $\mathrm{Sr})$. These elements are naturally found in soil as macro-elements. The contents of these elements are variable and are not related to any anthropogenic activities. Their sources are mainly natural phenomena such as rock weathering and chemical processes in soil. Occurrence of this factor is typical for the oldest formations in the Republic of Macedonia (Proterozoic micaschist and Proterozoic gneisses).

Factor $2(\mathrm{Co}, \mathrm{Cr}, \mathrm{Ni})$ also presents a geogenic factor. These determined elements are considered 'natural' because their origin is primarily crustal, soil particles suspended and transported by wind. High factor loadings are related to some old formation as Neogene dacites, andesites and pyroclastites and Pliocene unconsolidated sediments.

Factor $3(\mathrm{As}, \mathrm{Cd}, \mathrm{Cu}, \mathrm{Pb})$ associates chemical elements that indicate anthropogenic influence in the studying area (Figure 24). This association of elements was expected because of the studying area geology and the open pit mining and flotation activities. The acid drainage rapidly dissolved the elements, leading to increased content in soil. The open ore pit and flotation tailings dump allow direct exposure of the finest ore particles to the atmos- phere. Corpuscle dust from the surface layer of ore body and soil is spread in the atmosphere by the winds, thus performing atmospheric distribution of these elements in the vicinity of the mine. High loading value for this factor for $\mathrm{Cd}$ was also as a result of anthropogenic activity. Urban elements and those related to mine activities in dust are associated with fine particles, which are preferentially mobilized by wind and trapped in attics.

From the distribution map of Factor 3 scores and distribution maps for $\mathrm{Cu}$, As and $\mathrm{Cd}$ (Figures 24-27) it is clearly visible that the higher content of these elements is deposited in the close vicinity of the mine. Maps of areal element deposition from Factor 3 scores results from principal factor analysis (Figure 24), which shows that attic dust samples with an increased content of copper have an increased content for the rest of the elements from this Factor; this confirms the influence of present copper mine, flotation plant and flotation tailings dam.

Enrichment ratio (the content in attic dust samples from the affected area / the content in the rest of area) for $\mathrm{As}, \mathrm{Cd}$ and $\mathrm{Pb}$ is between 1.43.7 times, but the highest enrichment ratio of 4 is found for $\mathrm{Cu}$ [90]. Significant difference of population is additionally verified with the ANOVA test (analyzing of variance). This is because of the presence of the mine and mining copper minerals, which results in an introduction of higher copper content in environment.

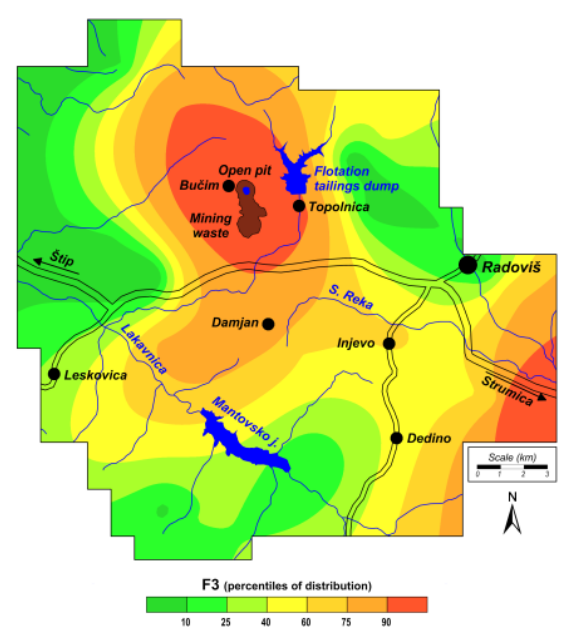

Figure 24. Spatial distribution of Factor 3 scores $(\mathrm{As}, \mathrm{Cu}, \mathrm{Pb})$ in attic dust samples [90] 


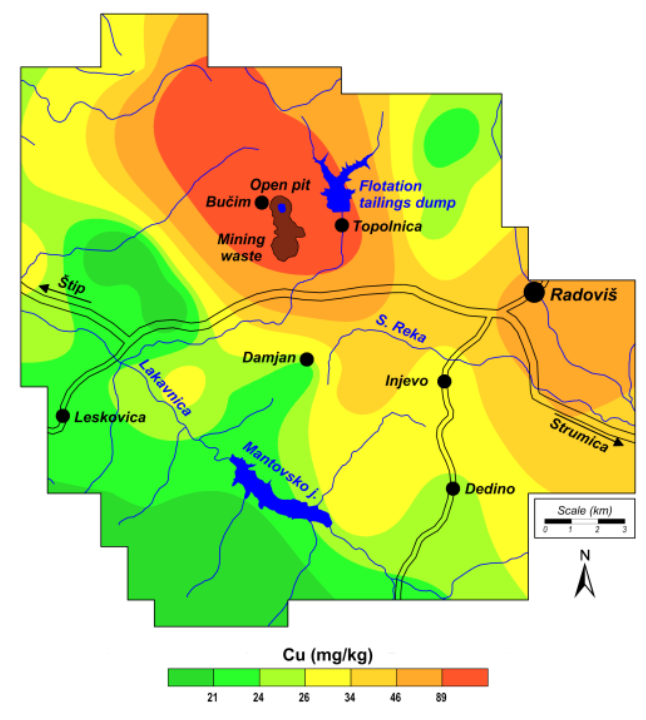

Figure 25. Spatial distribution of copper [92]

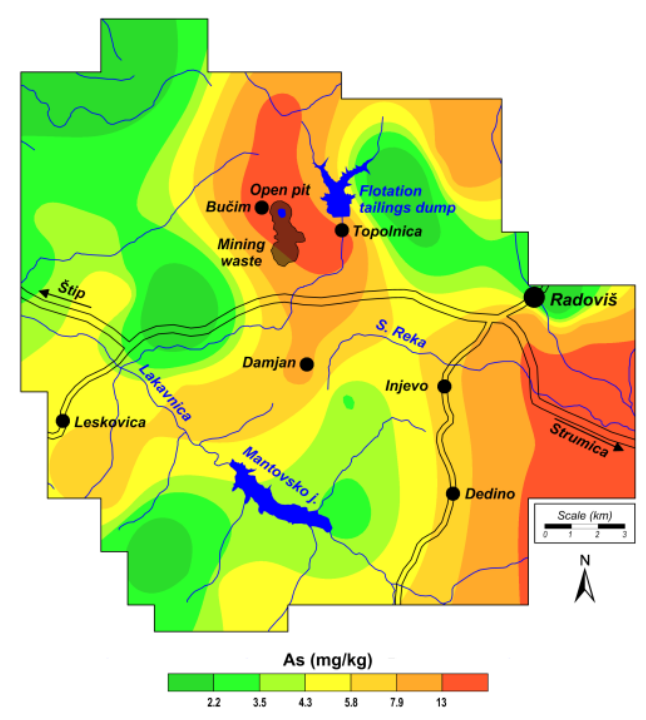

Figure 26. Spatial distribution of arsenic [90]

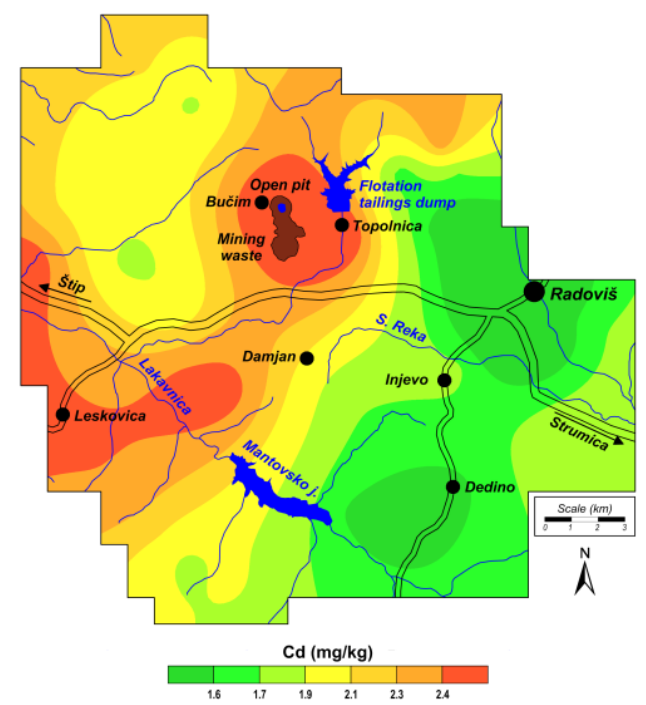

Figure 27. Spatial distribution of cadmium [90]

\section{Air pollution study in the Bucim mine area with deposited dust}

The Bučim copper mine environ was monitored for assessing the heavy metals distribution by the characterization of 17 elements content in total deposited dust collected during 2009. The element contents were determinated using atomic emission spectrometry with inductively coupled plasma (ICP-AES). Bučim and Topolnica villages and the town of Radoviš were chosen as sampling spots.

The amount of total deposited dust that is spread in the air is presented in Figure 28. It is evident that a large amount of deposited dust was recorded in the close vicinity of the mine (villages Bučim and Topolnica), where in some periods of the year were the values are above the maximum permitted amount of dust powder $\left(300 \mathrm{mg} \mathrm{m}^{-2} \mathrm{~d}^{-1}\right)$. Maximum value for the total deposited dust $\left(815 \mathrm{mg} \mathrm{m}^{-2} \mathrm{~d}^{-1}\right)$ was obtained in August in the village of Bučim. This is the highest value for the amount of total deposited dust compared to the other two places. The annual average for the total deposited dust in the vicinity of the village of Bučim is $489 \mathrm{mg} \mathrm{m}^{-2} \mathrm{~d}^{-1}$, for Topolnica $309 \mathrm{mg} \mathrm{m}^{-2} \mathrm{~d}^{-1}$, and accounted for Radoviš $97 \mathrm{mg} \mathrm{m}^{-2} \mathrm{~d}^{-1}$. A lower value was obtained for the amount of the total deposited dust in the village of Topolnica environ, while for Radoviš there was obtained a much lower value (Figure 28).

It was found that the median value for the copper content in the deposited dust samples taken from the studied area is $158 \mathrm{mg} \mathrm{kg}^{-1}$ and the $\mathrm{min} / \mathrm{max}$ range of values shows much higher content of this element in the samples from the mining area (ranges from 52 to $1182 \mathrm{mg} \mathrm{kg}^{-1}$ ) (Figure 29). Similar results were obtained for the distribution of $\mathrm{Fe}, \mathrm{Pb}$ and $\mathrm{Zn}$ thereby the median value and the $\mathrm{min} / \mathrm{max}$ range for these elements indicate their increased content.

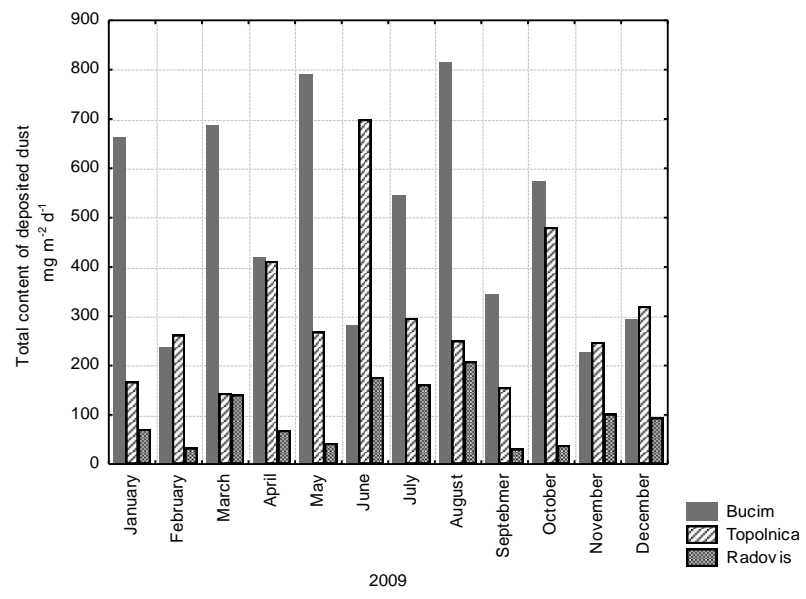

Figure 28. The total content of deposited dust [91] 


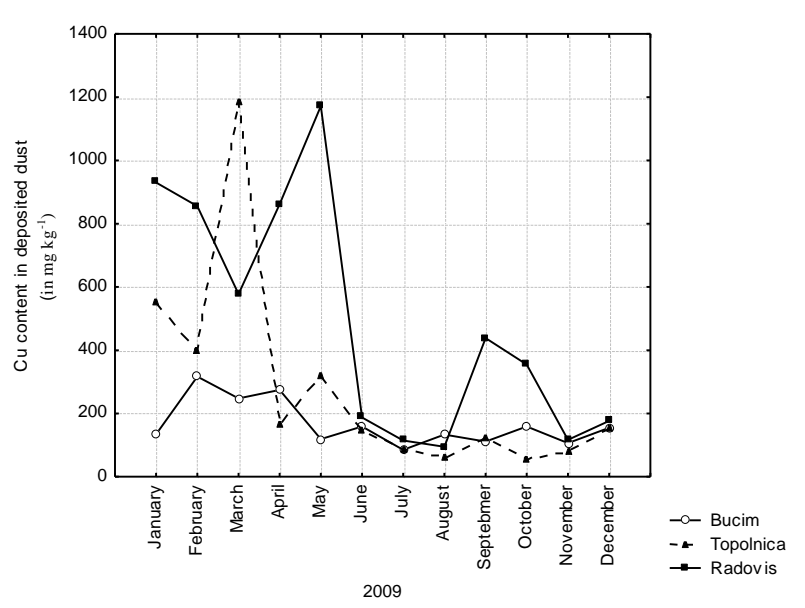

Figure 29. Trends of copper content in deposited dust through the whole year [91]

\section{Heavy metals toxicity and bioaccumulation in vegetables from copper mine environ}

The levels of 8 elements (As, $\mathrm{Cd}, \mathrm{Cr}, \mathrm{Cu}, \mathrm{Fe}$, $\mathrm{Ni}, \mathrm{Pb}$ and $\mathrm{Zn}$ ) contents were determined in various vegetables (garlic, Allium sativum, onion, Allium cepa, and parsley, Petroselinum crispum), cultivated around copper mine environ in 2012 [98]. The first locality (1), the village of Topolnica, was the most polluted region, affected with the works of copper mine. The second locality (2), the village of Damjan, is air-distanced $4 \mathrm{~km}$ from the flotation tailings dam and $2 \mathrm{~km}$ from the ore wastes dam from "Bučim" copper mine. This settlement is affected with the former iron mine "Damjan", too. The third sampling location (3), the village of Lakavica, is air distanced $12 \mathrm{~km}$ from the pollution source. The fourth sampling locality (4), the town of Stip, was used as a control location with the third location and to serve as a measurement for the impact of the urban environment.

The elements contents were analyzed separately in the edible vegetable parts, across the root. For arsenic half of the values were found below the limit of detection $\left(<0.5 \mathrm{mg} \mathrm{kg}^{-1}\right)$ for the three vegetable species. The maximum value for the $\mathrm{Cd}$ contents was obtained $0.25 \mathrm{mg} \mathrm{kg}^{-1}$ from $A$. cepa root. The range values for the $\mathrm{Cr}$ contents were from 0.1 $\mathrm{mg} \mathrm{kg}{ }^{-1}$ to $3.43 \mathrm{mg} \mathrm{kg}^{-1}$. The normal distribution of copper contents was influenced with the dust distribution from copper mine enriched with toxic elements ( $\mathrm{As}, \mathrm{Cd}, \mathrm{Pb}$ and $\mathrm{Zn}$ ). Thus, the $\mathrm{Cu}$ contents were in the range of $2.6-46 \mathrm{mg} \mathrm{kg}^{-1}$. The maximum value for the $\mathrm{Cu}$ content was obtained from A. cepa root. Significant enriches were obtained for iron content in A. cepa and A. sativum roots $(\sim 0.1 \%)$.

Soil analyses have shown $\sim 3 \% \mathrm{Fe}$ contents. Nickel contents were in the range of $0.1-4 \mathrm{mg} \mathrm{kg}^{-1}$, and showed no significant deviation from the set standards for metals in foods. The lead concentrations in vegetables commonly are related with the $\mathrm{Ca}, \mathrm{P}, \mathrm{Fe}$ and $\mathrm{Cu}$ contents. Therefore, $\mathrm{Pb}$ contents were analyzed as potentially toxic metal, due to $\mathrm{Cu}$ anthropogenic enrichment in the investigated area. Range values $\left(0.3-2 \mathrm{mg} \mathrm{kg}^{-1}\right)$ point to partially contamination. Lead contents $>2 \mathrm{mg} \mathrm{kg}^{-1}$ were obtained from A. cepa and A. sativum roots. $P e$ troselinum crispum roots accumulate with an median contents $\sim 1 \mathrm{mg} \mathrm{kg}^{-1}$. The $\mathrm{Zn}$ contents for $A$. $s a$ tivum range from 7 to $41 \mathrm{mg} \mathrm{kg}^{-1}$, for $A$. cepa ranges from 8 to $52 \mathrm{mg} \mathrm{kg}^{-1}$, and for the Petroselinum crispum range from 11 to $30 \mathrm{mg} \mathrm{kg}^{-1}$.

On the basis of the total contents of the analyzed elements in soil it can be considered that significant pollution does not occur. There were some exceptions for the $\mathrm{Cu}$ contents, at the (1) site (101 $\mathrm{mg} \mathrm{kg}{ }^{-1}$ ) and for the $\mathrm{Pb}$ and $\mathrm{Zn}$ at (4) site (84 and $181 \mathrm{mg} \mathrm{kg}^{-1}$ ). The copper mine affects only the very close surrounding area, as previously investigations showed [87].

The correlations of $\mathrm{Fe}-\mathrm{Cr}(r=0.94)$ and $\mathrm{Cu}-$ $\mathrm{Cd}(\mathrm{r}=0.81)$ were selected as significant relations in the elements accumulations. The geogenic impact of the region is related to the Eocene flysh and molase, as well as to the oldest formations: Pleistocene sediments and Proterozoic gneisses [90]. The correlation $\mathrm{Cu}-\mathrm{Cd}$ relates to the anthropogenic influence of the copper mine as previously was found using moss and lichen plant species as sampling media [87]. For better visibility of elements correlations, clustering was used for minimizing the elements distribution. The elements correlations go this way: $\mathrm{As}-\mathrm{Pb}-\mathrm{Ni}$; $\mathrm{Cr}-\mathrm{Fe}$; $\mathrm{Cd}-\mathrm{Cu}-\mathrm{Zn}$.

Bioaccumulation and mobility of heavy metals were determined with three soil extraction methods: in $0.1 \mathrm{~mol} \mathrm{l}^{-1} \mathrm{HCl}$; in $\mathrm{H}_{2} \mathrm{O}$ and in a mixed buffered solution $(\mathrm{pH}=7.3)$ of triethanolamine $(0.1$ mol l $\left.\mathrm{l}^{-1}\right)$ with $\mathrm{CaCl}_{2}\left(0.01 \mathrm{~mol} \mathrm{l}^{-1}\right)$ and diethylenetriaminepentaacetic acid $\left(0.005 \mathrm{~mol} \mathrm{l}^{-1}\right)$. Heavy metals contents were investigated for determining the bioaccumulation properties in vegetables parts in order to assess the health risk of consuming food.

With the simulations of these extractions we were able to assess the level of plant-available elements and the conditions in which plants grew. For $\mathrm{Cd}, \mathrm{Cr}$ and $\mathrm{Ni}$ very low variations were identified between the extraction solutions (Figure 30). For arsenic $1.6 \%$ were extracted using $0.1 \mathrm{~mol} \mathrm{l}^{-1} \mathrm{HCl}$ and the same results were obtained for extraction with DTPA- $\mathrm{CaCl}_{2}-\mathrm{TEA}$. The sequestering reagents were much effective in the case of $\mathrm{Cu}$ and $\mathrm{Pb}$ (extracted contents of $12.4 \%$ and $3.6 \%$, respectively). For the Fe content the same effect was obtained in 
the water extraction and the DTPA extraction, but the efficiency was not significant $(<1 \%)$. In general the results indicated that none of the plant species was identified as a hyperaccumulator because all species accumulated $\mathrm{As}, \mathrm{Cd}, \mathrm{Cr} \mathrm{Cu}, \mathrm{Fe}, \mathrm{Ni}, \mathrm{Pb}$, and $\mathrm{Zn}$ less than $1000 \mathrm{mg} \mathrm{kg}^{-1}$ [99].

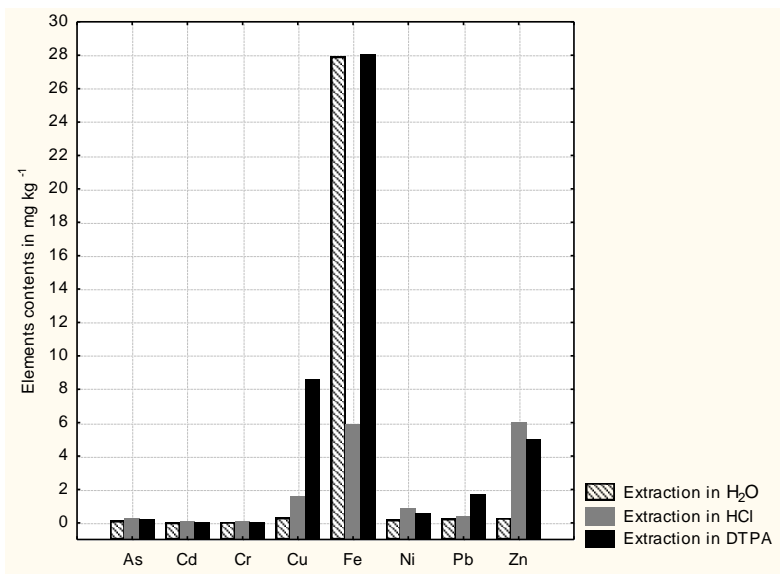

Figure 30. Bar plots for extracted elements contents in three different extracts solutions $\left(\mathrm{H}_{2} \mathrm{O}, 0.1 \mathrm{M} \mathrm{HCl}\right.$ and DTPA- $\mathrm{CaCl}_{2}$-TEA) [98]

\section{MOSS BIOMONITORING OF AIR POLLUTION IN THE VICINITY OF SASA Pb-Zn MINE [100]}

"Sasa" mine was in production for over 45 years, annually yielding around 90,000 tonnes of $\mathrm{Pb}-\mathrm{Zn}$ high quality concentrate. The Sasa $\mathrm{Pb}-\mathrm{Zn}$ deposit lies within the Sasa-Toranica mining district in the Osogovo Mountains in the eastern part of Macedonia (Figure 31). The geology of the Toranica-Sasa ore field comprises various rocks of both metamorphic and igneous origin, with the lat- ter of Tertiary age. The most economically valuable mineralisation is closely related to that of quartzgraphite schists, with the ore consisting mainly of: galena, sphalerite, chalcopyrite and pyrite [101]. In 2003 a major environmental disaster took place in the investigated region when part of the Sasa mine tailings dam collapsed and caused an intensive flow of tailings dam material through the valley of Kamenica [102]. Between 70,000 and $100,000 \mathrm{~m}^{3}$ of tailings dam material was discharged into Lake Kalimanci, causing significant ecological damage and potentially air pollution hazardously conditions were occurred [103].

Disposed mining waste rock materials create environmentally hazardous conditions for residents and ecosystems at a local level. Estimated hazards are toxic/acidic effluents, uncontained waste rock, dust emissions and unsecured workings, poorly contained and unstable tailings wastes. Therefore, a moss biomonitoring was conducted with a total of 36 moss samples of Hypnum cupressiforme (Hedw.) and Camptothecium lutescens (Hedw.) collected in the period September-October 2012 (Figure 31). The analyses of total 21 elements contents (Al, As, $\mathrm{Ba}, \mathrm{Ca}, \mathrm{Cd}, \mathrm{Co}, \mathrm{Cr}, \mathrm{Cu}, \mathrm{Fe}, \mathrm{Hg}, \mathrm{K}, \mathrm{Li}, \mathrm{Mg}, \mathrm{Mn}, \mathrm{Na}$, $\mathrm{Ni}, \mathrm{P}, \mathrm{Pb}, \mathrm{Sr}, \mathrm{V}, \mathrm{Zn}$ ) in digest samples were performed applying ICP-AES, ETAAS and cold vapor atomic absorption spectrometry (CVAAS).

Multivariate factor statics shown for elemental associations: F1 (Al-Co-Cr-Fe-Li-Ni-V), F2 $(\mathrm{Cd}-\mathrm{Pb}-\mathrm{Zn}), \mathrm{F} 3(\mathrm{Ca}-\mathrm{Mg}-\mathrm{Na}-\mathrm{P})$ and $\mathrm{F} 4(\mathrm{Cu})$. Factor 1 (Al-Co-Cr-Fe-Li-Ni-V) and Factor 3 (Ca-Mg-Na$\mathrm{P})$ associates chemical elements that indicate geogenic distribution in the studying area considering generalized geology of the region. Contents of these elements are variable and are not related to any anthropogenic activities.

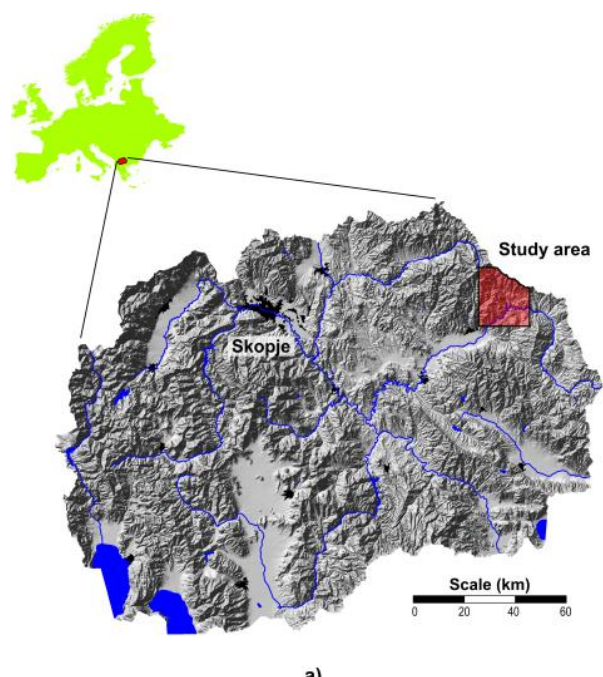

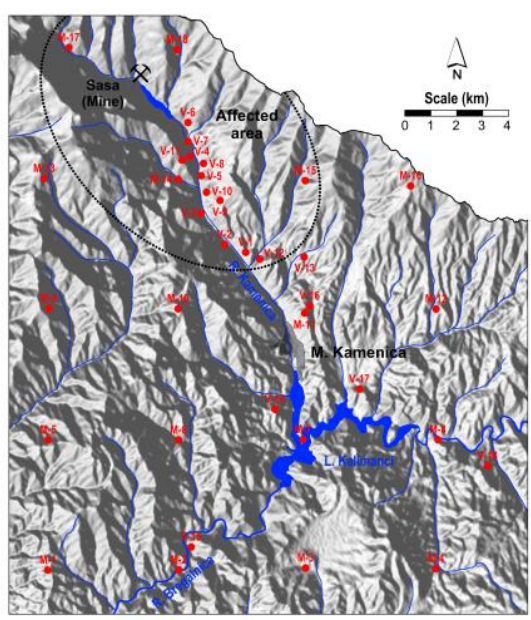

Figure 31. Location of the study area (a) and sampling network locations (b) [100] 
Factor $2(\mathrm{Cd}-\mathrm{Pb}-\mathrm{Zn})$ and Factor $4(\mathrm{Cu})$ are directly connected with the corpuscle dust from the surface layer of flotation tailings and soil spread to the atmosphere by the winds, through which is performed atmospheric distribution of these elements in the vicinity of the mine. The areal distribution of these anthropogenic elements (Figures 32, 33) gives better visualization for the anthropogenic introducing of relatively high contents of these toxic metals (max. values: $3.7 \mathrm{mg} \mathrm{kg}^{-1}$ for $\mathrm{Cd}$ and $\sim 450 \mathrm{mg} \mathrm{kg}^{-1}$ for $\mathrm{Pb}$ and $\mathrm{Zn}$ ). Thus, potentially hazardous contents were considered for $\mathrm{Cd}>0.20 \mathrm{mg} \mathrm{kg}^{-1}$; for $\mathrm{Cu}>9$ $\mathrm{mg} \mathrm{kg}^{-1}$; contents for $\mathrm{Pb}>18 \mathrm{mg} \mathrm{kg}^{-1}$ and contents for $\mathrm{Zn}>24 \mathrm{mg} \mathrm{kg}^{-1}$. This area affected with dust deposition (distributed from flotation tailings) can be marked as a polluted one. The area is affected with a significant hazardous contents with $\mathrm{Cd}>1.30$ $\mathrm{mg} \mathrm{kg}^{-1}$ and $\mathrm{Cu}$ contents $>22 \mathrm{mg} \mathrm{kg}^{-1}$ (Figure 33). For $\mathrm{Pb}$ and $\mathrm{Zn}$ hazardous contents were found only in the affected area $>130$ and $160 \mathrm{mg} \mathrm{kg}^{-1}$, respectively (Figure 32).
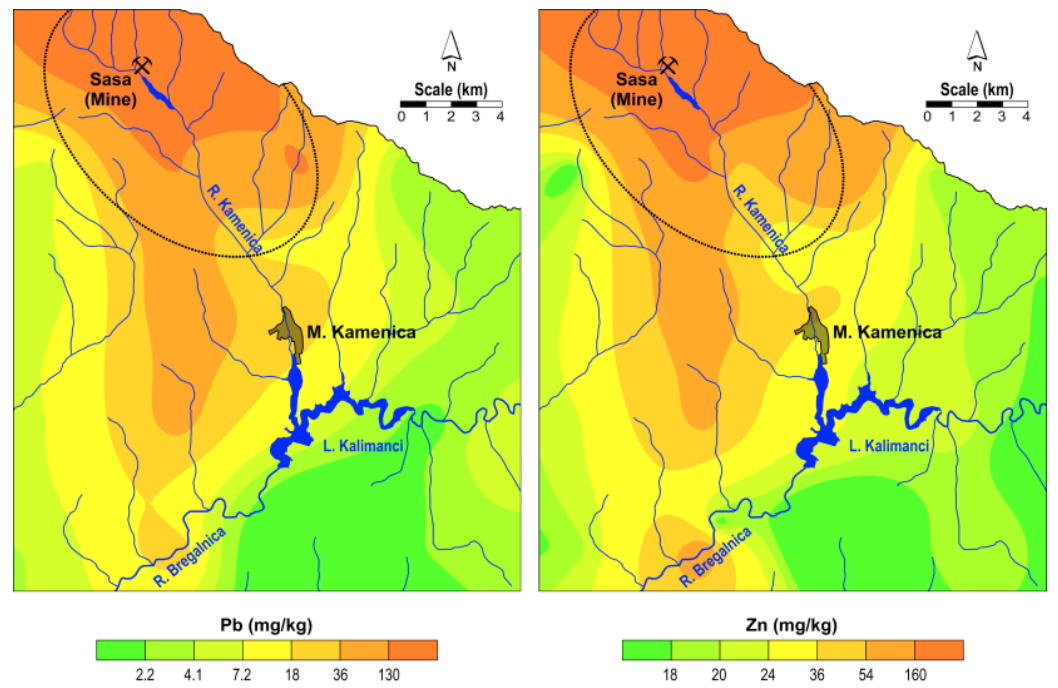

Figure 32. Spatial distribution of lead (left) and zinc (right) in moss samples [100]
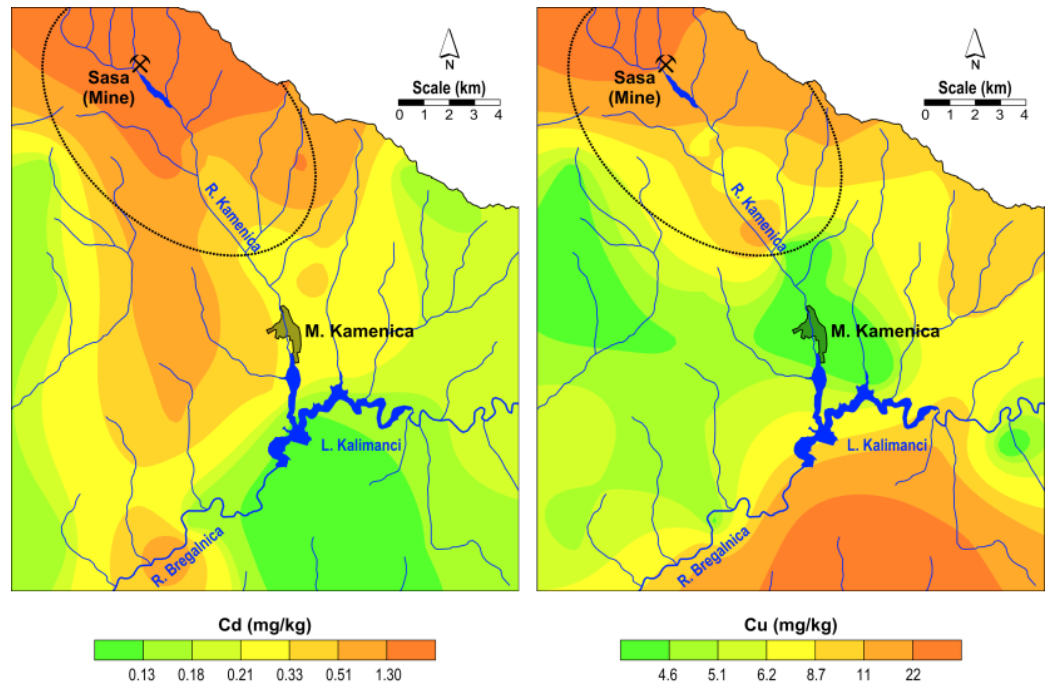

Figure 33. Spatial distribution of cadmium (left) and copper (right) in moss samples [100]

Aerial distribution of dust particles is certainly in relation to the distance at which they can reach. Therefore, we set up a functional dependence of the content of heavy metals versus distance from the emission source. Functional interdepend- ence relation of elements contents across the distance from the pollution source was determined. The higher contents of cadmium, lead and zinc were distinguished as main anthropogenic introduced elements in the mine environ (Figure 34). 


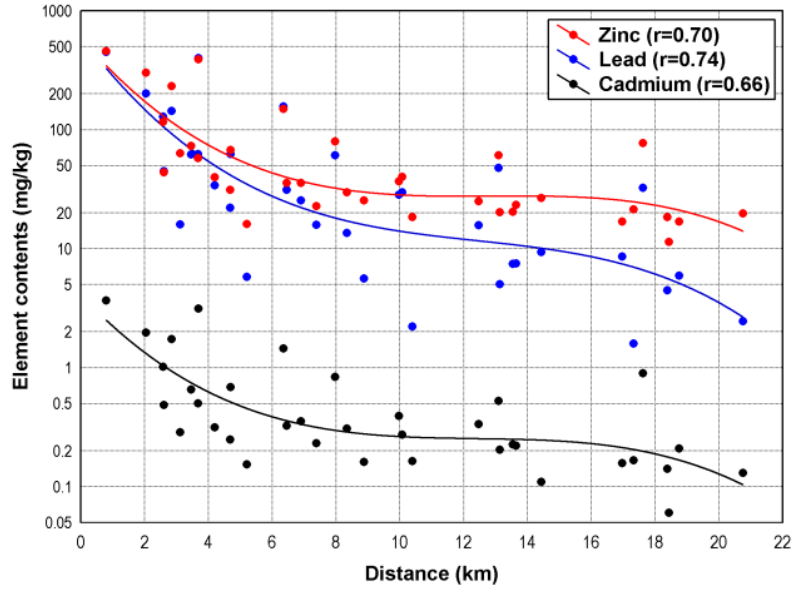

Figure 34. Bioaccumulation of $\mathrm{Cd}, \mathrm{Pb}$ and $\mathrm{Zn}$ and functional interdependence relation with the distance from the pollution source [100]

Significant higher correlation derived from the relation given in Figure 34, indicating that distancing from emission source results in decreased bio-accumulating of these heavy metals in moss.

\section{MOSS BIOMONITORING OF AIR POLLUTION IN THE VICINITY OF ZLETOVO-PROBIŠTIP Pb-Zn MINE AND FLOTATION PLANT [104]}

The Zletovo $\mathrm{Pb}-\mathrm{Zn}$ deposit is situated along the active continental margin and is intimately associated with the Tertiary volcanism and hydrothermal activity of the area. The Zletovo mine is located $5 \mathrm{~km} \mathrm{NW}$ from the Zletovo village and about $7 \mathrm{~km}$ from the town of Probištip (Figure 35). Continuous exploitation of the mine started after the Second World War and it has an annual capacity of 300,000 tons $(9 \% \mathrm{~Pb}$ and $2 \% \mathrm{Zn})$ and significant concentrations of $\mathrm{Ag}, \mathrm{Bi}, \mathrm{Cd}$ and $\mathrm{Cu}$. The mine is active to date with production of $\mathrm{Pb}-\mathrm{Zn}$ concentrate. Mineral association comprises galena (principal ore mineral) and sphalerite, with subordinate pyrite, lesser amounts of siderite, chalcopyrite, and occasional pyrhotine, marcasite, and magnetite. Ore is concentrated by flotation at the town of Probištip and tailings stored in two impoundments situated in adjacent valleys [101, 105].

In total 23 local characteristic moss species were used as biomonitors (Hypnum cupressiforme, Scleropodium purum and Campthotecium lutescens) which were collected with a very dense sampling network of $5 \times 5 \mathrm{~km}$. The analyses of total 21 elements contents in digest samples were performed by atomic emission spectrometer with inductively coupled plasma, ICP-AES applying an

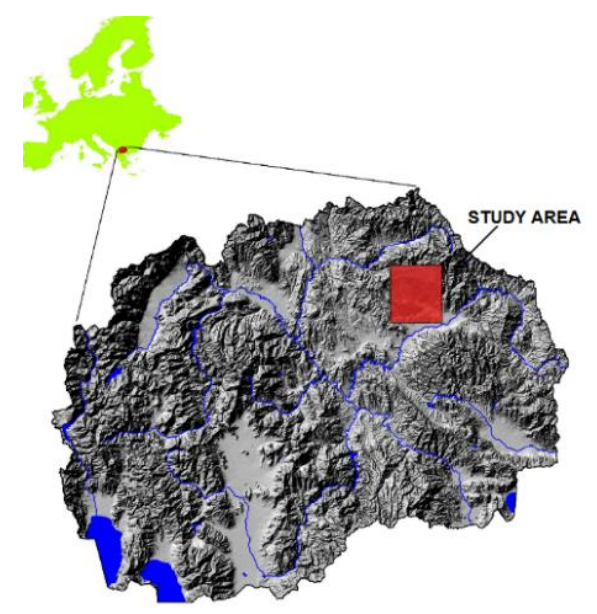

a)

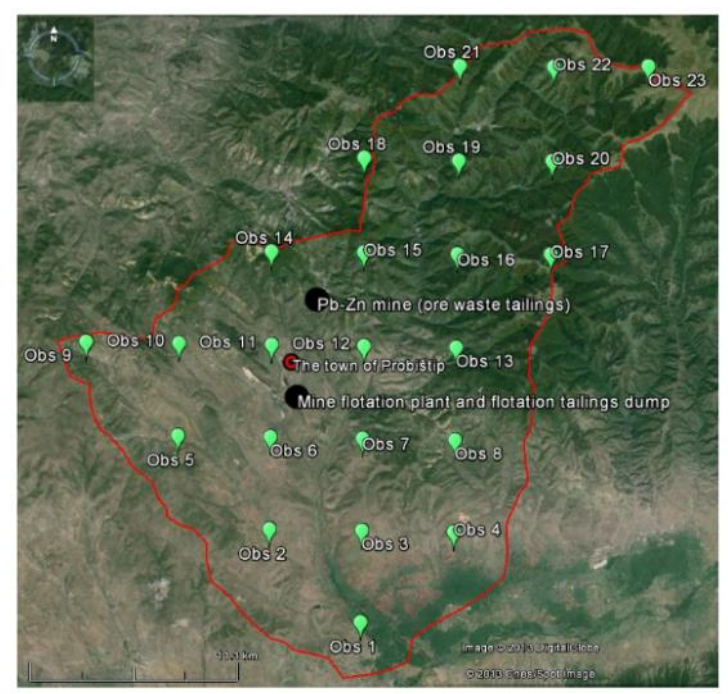

b)

Figure 35. The location of the study area (a) and sampling network within Probištip region (b) [104]

ultrasonic nebulizer CETAC (ICP/U-5000AT+) for better sensitivity.

The median values for the main anthropogenic elements $(\mathrm{Pb}$ and $\mathrm{Zn})$ were 15.4 and $33.8 \mathrm{mg} \mathrm{kg}^{-1}$, respectively. Compared to corresponding values for the whole territory of the Republic of Macedonia enrichments values were found [37]. For the $\mathrm{Pb}$ contents the large scale/small scale enrichments were calculated as 3.35. For the $\mathrm{Zn}$ content the enrichment value was $1.7\left(20 \mathrm{mg} \mathrm{kg}^{-1}\right.$ for the whole territory of the Republic of Macedonia). The contents of $\mathrm{Cd}, \mathrm{Cu}$ and $\mathrm{Mn}$ were also assumed as anthropogenically influenced from the emission source, following their range values: $0.08-1.73 ; 4.11-21.4$ and $55.5-376$ $\mathrm{mg} \mathrm{kg}{ }^{-1}$, respectively. The manganese distribution was assumed as normal on the basis of the histograms visualization of data set and comparison with the geology maps of distribution. However, the mine 
and flotation works influence as an anthropogenic enrichment, and give another point of view. Median values were compared with the corresponding values from the whole territory of the Republic of Macedonia and there were no significant differences for the $\mathrm{Cd}$ and $\mathrm{Mn}$. Only for $\mathrm{Cu}$ contents enrichments were found, calculated $\sim 2$ times [37].

Values for the contents of plant-biogenic elements: $\mathrm{Ca}, \mathrm{K}, \mathrm{Na}, \mathrm{P}, \mathrm{Mg}$ undergoes with the contents of macro- and micro-element nutrients in moss tissue. There is no significant trend for variations in moss tissue biogenic elements compared to moss study tissue for whole territory of the Republic of Macedonia [37]. The contents for the lithogenic elements $(\mathrm{Al}, \mathrm{Cr}, \mathrm{Fe}, \mathrm{Mo}, \mathrm{Ni})$ relies on the geology of the region. As it was previously presented by Barandovski et al. [37] the trend for $\mathrm{Al}$ distribution for the whole territory of the Republic of Macedonia varies in the range $0.05 \%-0.87 \%$, and strongly relays on the lithology of the area (dominant magmatic and volcanic rocks, enriched with quaternary sediments). Iron contents in moss tissue were accumulated in range of $0.13 \%-0.83 \%$. The $\mathrm{Fe}$ distribution follows the $\mathrm{Al}$ distribution, probably because of the same lithological impact. For the rest of the lithological distributed elements $(\mathrm{Cr}, \mathrm{Mo}$ and $\mathrm{Ni}$ ) median values were in accordance with their normal distribution for the whole territory of the Republic of Macedonia (3.44, 0.18 and 3.75 $\mathrm{mg} \mathrm{kg}^{-1}$, respectively).

Principal components and classification analysis as data reduction method for a description of supplementary variables and cases was applied to the same data set (elements contents) and moss species as cases. Therefore, consecutive principle components are extracted as PC1 and PC2 (using scree plot as extraction method (Figure 36).

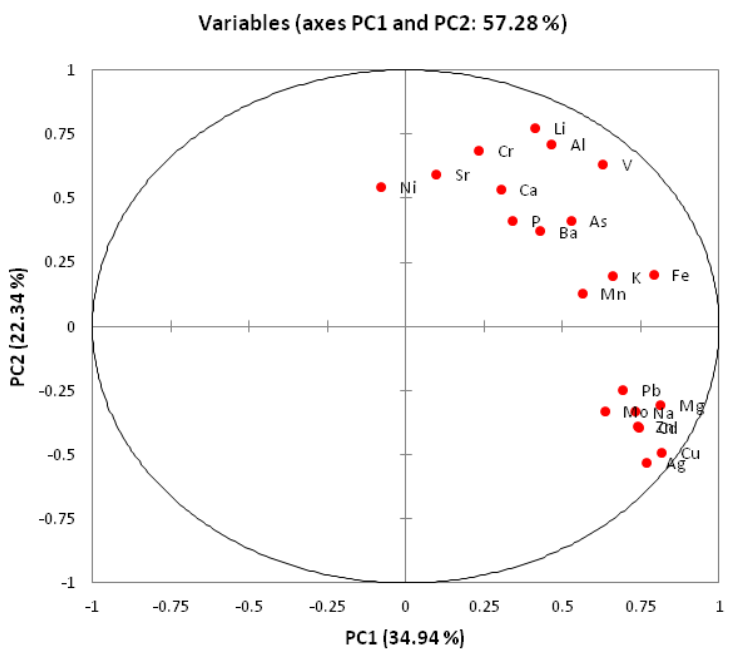

Figure 36. Principal components for elements contents [104]
The first principal component $\mathrm{PC} 1$ associates the elements $\mathrm{Cu}>\mathrm{Ag}>\mathrm{Mg}>\mathrm{Cd} \sim \mathrm{Zn}>\mathrm{Na}>\mathrm{Pb} \sim \mathrm{Mo}$ (mostly anthropogenetic elements), sequenced according to the expressions of component patterns. The second principle component PC2 associates lithogenic elements $\mathrm{Li}>\mathrm{V}>\mathrm{Al}>\mathrm{Cr}>\mathrm{Ca} \sim$ As.

\section{MOSS BIOMONITORING OF AIR POLLUTION IN THE VICINITY OF TORANICA Pb-Zn MINE [106]}

The "Toranica" mine is located on the slopes of Osogovo Mountains near the MacedonianBulgarian border, $18 \mathrm{~km}$ away, and $20 \mathrm{~km}$ away from the town of Kriva Palanka. Mine "Toranica" is designed as a modern underground mine with a production capacity of 700,000 tons of ore per year. Ore from the deposit "Toranica" appears in three textured types: pure ore with representation of $51 \%$, massive ore with $29 \%$ and impregnated ore with $20 \%$. The ore consists mainly of galena, sphalerite, chalcopyrite and pyrite [107]. The ore reserves were estimated to be 12.6 million tones, with 4.47 $\%$ of $\mathrm{Pb}, 2.93 \%$ of $\mathrm{Zn}$ and $20 \mu \mathrm{g} \mathrm{g}{ }^{-1}$ of $\mathrm{Ag}$ [108]. The flotation plant for the production of $\mathrm{Pb}$ and $\mathrm{Zn}$ concentrates is situated close to the mine. Toranica concentrator flowsheet gives the following technological results: $\mathrm{Pb}+\mathrm{Zn}$ collective concentrate with an average of $15 \%$ of $\mathrm{Pb}$ and $35 \%$ of $\mathrm{Zn}$ and $\mathrm{Pb}$ selective concentrate with an average of $73 \%$ of $\mathrm{Pb}$ and $4,3-5 \%$ of $\mathrm{Zn}$ [107].

Therefore, the lead and zinc mine "Toranica" environ was monitored as a potentially polluted area with anthropogenically introduced higher contents of certain heavy metals. A total of $250 \mathrm{~km}^{2}$ area was monitored, limited with coordinates $\mathrm{N}$ : $42^{\circ} 10^{\prime}-42^{\circ} 20^{\prime}$ and E: $22^{\circ} 17^{\prime}-22^{\circ} 28^{\prime}$, located in the north-eastern part of the Republic of Macedonia (Figure 37). The dominant moss species were Homalothecium lutescens (52\% of 39 total collected moss species) and Hypnum cupressiforme (36\% of total collected moss species) which were collected in 2011.

The analyses of 23 elements contents in digested samples were performed by applying: ICPAES (Al, B, Ba, Ca, Cr, Cu, Ga, Fe, K, Li, Mg, Mn, $\mathrm{Na}, \mathrm{Ni}, \mathrm{P}, \mathrm{Pb}, \mathrm{Sr}, \mathrm{V}, \mathrm{Zn}$ ), ETAAS (As, Co, Cd) and CVAAS $(\mathrm{Hg})$. High contents of $\mathrm{Pb}$ and $\mathrm{Zn}$ were found (average values of 60 and $75 \mathrm{mg} \mathrm{kg}^{-1}$, respectively) in the area very close to the pollution source (Figure 38 ). Thus, the maximum values (420 $\mathrm{mg} \mathrm{kg}^{-1}$ for $\mathrm{Pb}$ and $180 \mathrm{mg} \mathrm{kg}^{-1}$ for $\mathrm{Zn}$ ) for the contents in moss occur in the very close vicinity of the pollution source. The median value for $\mathrm{Pb}(3.2 \mathrm{mg}$ 
$\mathrm{kg}^{-1}$ ) compared to the same value for the whole territory of the Republic of Macedonia (4.6 $\mathrm{mg} \mathrm{kg}^{-1}$ ) shows no enrichments at all [37]. When close mine locations were isolated from the rest of the study area an enrichment of 10 times was obtained for 12 samples $\left(33.4 \mathrm{mg} \mathrm{kg}^{-1}\right)$.

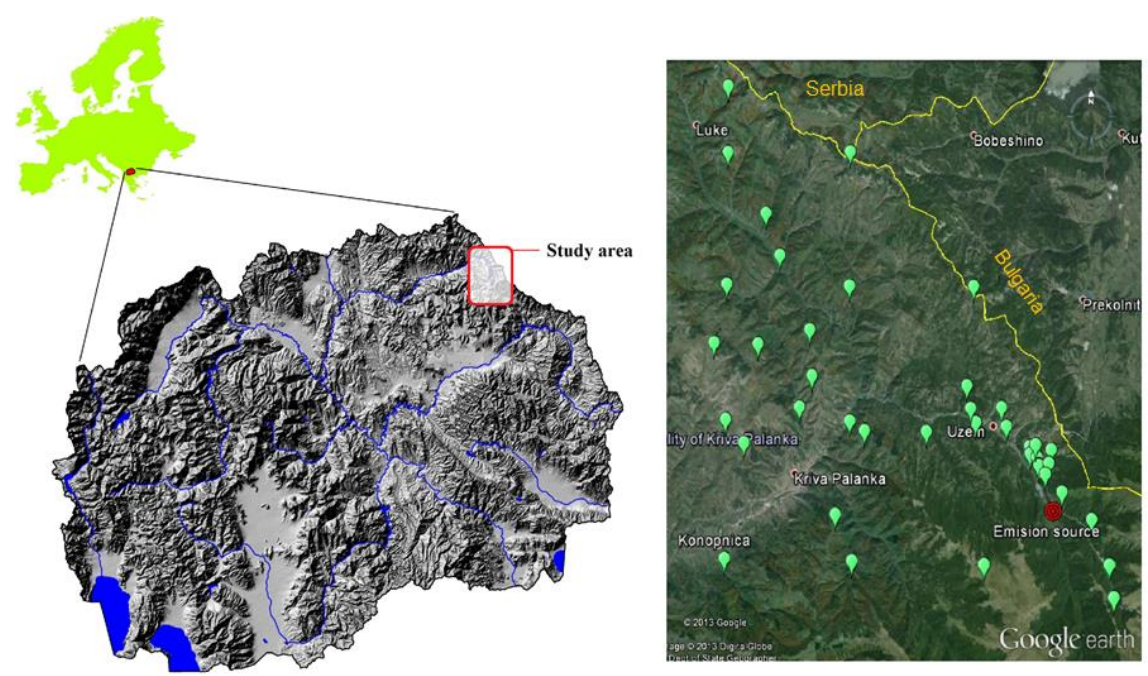

Figure 37. Location of the investigating area in the $\mathrm{Pb}-\mathrm{Zn}$ "Toranica" mine (left); moss sampling network of moss species [106]
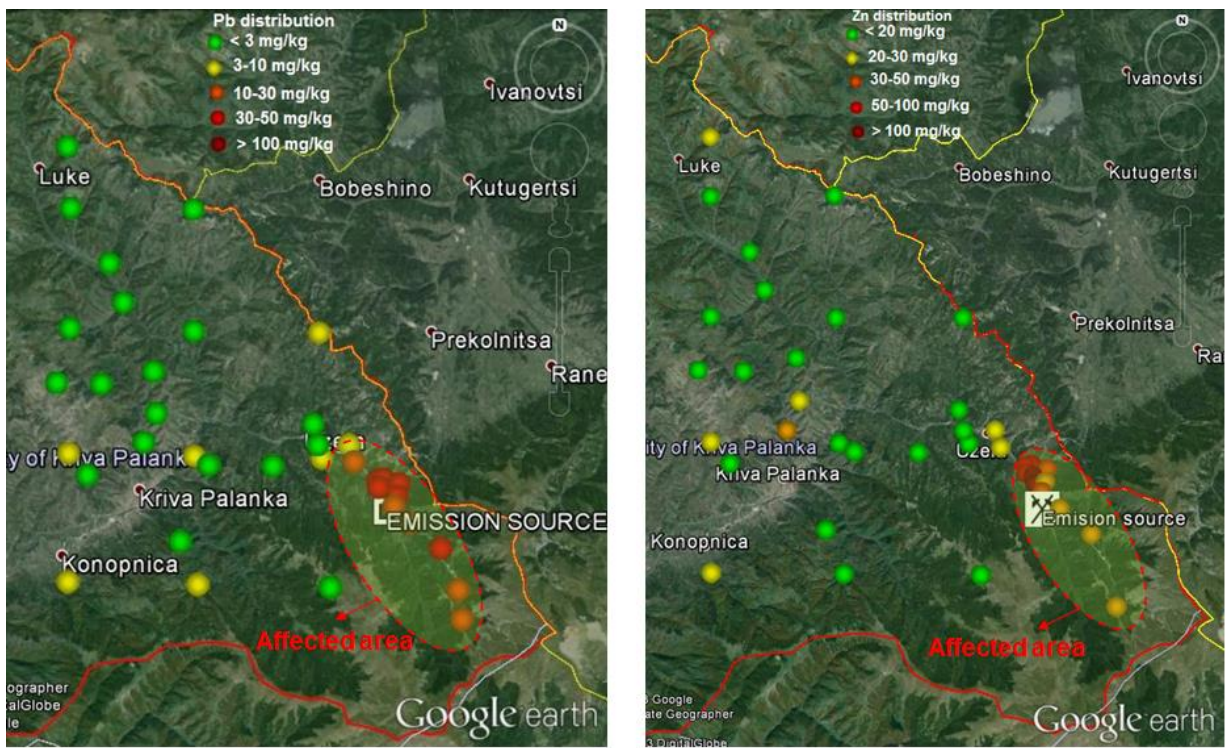

Figure 38. Areal total contents distribution of main anthropogenic markers of $\mathrm{Pb}$ (left) and $\mathrm{Zn}$ (right) in "Toranica" lead-zinc mine environ [106]

The rest of the potentially hazardous elements were distributed in ranges for As $(0.03-10.5$ $\left.\mathrm{mg} \mathrm{kg}{ }^{-1}\right), \mathrm{Cd}\left(0.06-1.62 \mathrm{mg} \mathrm{kg}^{-1}\right), \mathrm{Hg}(0.01-0.04$ $\left.\mathrm{mg} \mathrm{kg}{ }^{-1}\right)$, Ni $\left(0.45-9.43 \mathrm{mg} \mathrm{kg}^{-1}\right)$. The lead-zinc deposits usually are characterized with Mn contents as well. Therefore, the $\mathrm{Mn}$ contents were ranged in $30.4-815 \mathrm{mg} \mathrm{kg}^{-1}$, wherefrom they can be considered as geo-enrichments in the study area. Aerial distribution of dust particles is in relation to the distance at which they can reach. Therefore, a func- tional dependence of the content versus distance from the emission source was established (Figure 39). It is obvious from Figure 39 that distancing from emission source results in decrease of bioaccumulation of these heavy metals in moss. The results from this study show that $\mathrm{Pb}$ and $\mathrm{Zn}$, occurring as main markers for anthropogenic impacts of the pollution source associated with $\mathrm{As}, \mathrm{Cd}, \mathrm{Cu}$, and $\mathrm{Mn}$, strongly correlated in moss samples. 


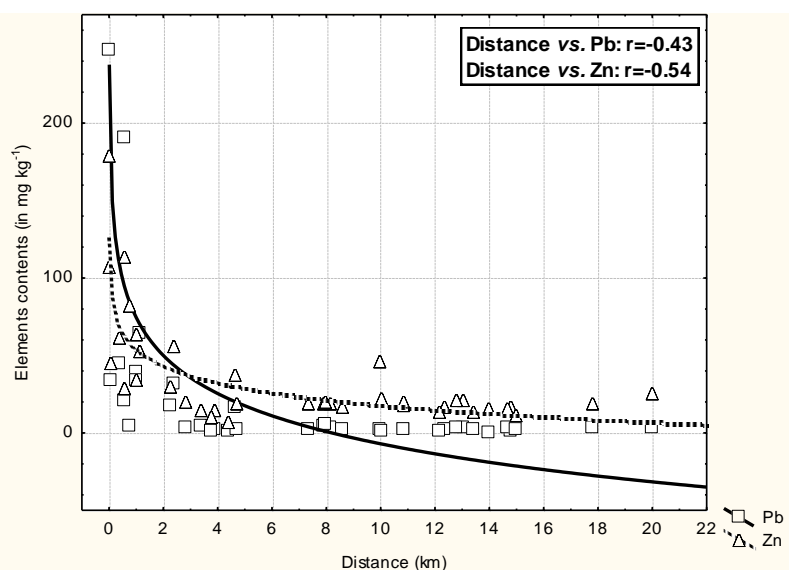

Figure 39. Exponential interdependence relation with the distance from the pollution source for $\mathrm{Pb}$ and $\mathrm{Zn}$ [106]

\section{POLLUTION WITH HEAVY METALS OVER THE BITOLA REGION}

The Bitola region, as well as the whole Pelagonia Valley, is rather southern positioned and due to the latitude should have an altered Mediterranean climate. However, although Pelagonia Valley is at a distance of 155 kilometers from the Adriatic Sea, and at about 130 kilometers from the Aegean Sea, the Mediterranean climate influence is not much felt, because of the high mountainous surrounding of the valley, and its own height above the sea level (it is between 571 and 770 meters). That is why the temperate-continental, continental and mountainous climate is mostly felt [50]. The microclimate is influenced by the air pollution caused by the bigger polluters (thermoelectric power plant REK Bitola, the city boiler rooms, the traffic, the chimneys of the houses and the industrial zone).

The Mining Power Complex "Bitola" is located on the periphery of Pelagonia plain near the village of Novaci and represents the bigger source of pollution in the Bitola environs. The plant which basic activity is the production of electricity and coal is the biggest in the system of the Macedonian electric power plant and consists of the mine "Suvodol" and thermoelectric power plant. The production in the plant started in 1980 and has a capacity of $660 \mathrm{MW}$. The open pit mine Suvodol is located $15 \mathrm{~km}$ to the east of Bitola and extends over 9.0 $\mathrm{km}^{2}$. The exploitation in the mine Suvodol started in 1977, while with the excavation of coal started in 1982. Now, the "Bitola" TEPS has about $700 \mathrm{MW}$ power capacity ( 3 units $\times 230 \mathrm{MW}$ ). The stack chimneys and cooling towers have heights of 250 and $120 \mathrm{~m}$, respectively. This TEPS burns lignites that originate from the open-cast "Suvodol". About 6 million tons of coal are burned annually in the
"Bitola" TEPS. The coal-combustion process is conducted at $900-1300{ }^{\circ} \mathrm{C}$. The bottom ash is highly abundant in unburned coal material and this product is combusted again in the boilers and then deposed on the open fly ash landfill with about 1 million tonnes per year [109].

\section{Atmospheric pollution around the thermoelectric power plant using a moss biomonitoring [110,111]}

The purpose of this study was to establish heavy metals atmospheric deposition in the town of Bitola and its surrounding area, by using the moss biomonitoring technique, and to define the extent of possible air pollution. The study area is located in the southwest part of the Republic of Macedonia (Figure 40), with largeness of $35 \mathrm{~km}(\mathrm{~W}-\mathrm{E}) \times 40$ $\mathrm{km}(\mathrm{S}-\mathrm{N})$, total $1400 \mathrm{~km}^{2}$.

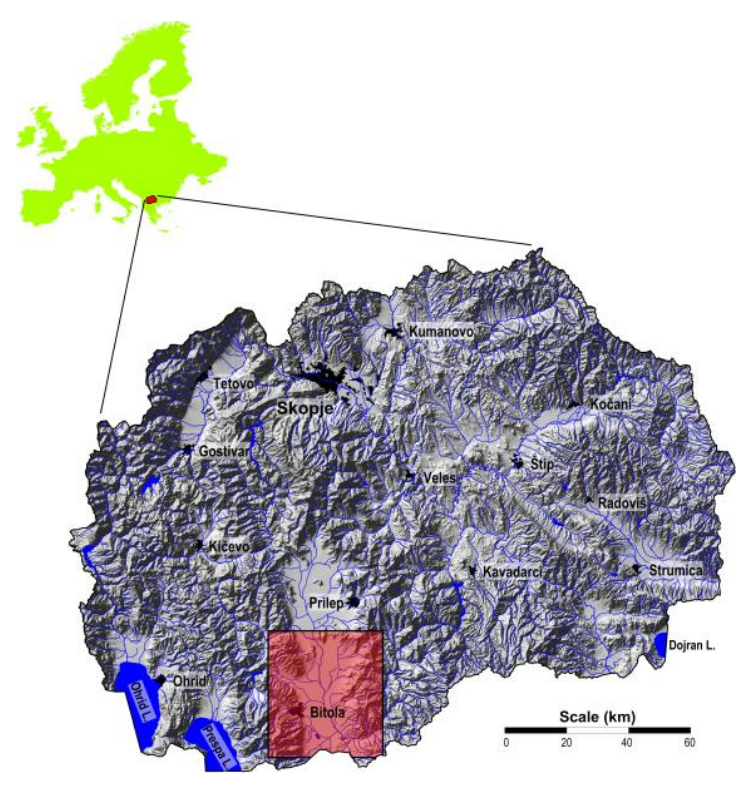

Figure 40. Studying area [110]

In the period from July to December 2010, 38 samples of mosses were collected. Dominant types of collected moss are Hypnum cupressiforme and Homalothecium lutescens. Microwave digestion system was applied for these samples. Atomic emission spectrometry with inductively coupled plasma (AES-ICP) and inductively coupled plasma - mass spectrometry (ICP-MS) were the techniques that were used. The following elements were determined: $\mathrm{Al}, \mathrm{As}, \mathrm{Be}, \mathrm{Bi}, \mathrm{Co}, \mathrm{Cr}, \mathrm{Cs}, \mathrm{Fe}, \mathrm{Ga}, \mathrm{Ge}$, Hf, In, Li, Ni, Rb, Sc, Ta, Te, Tl, V, Y, Zr, La, Lu, $\mathrm{Ru}, \mathrm{Pt}, \mathrm{B}, \mathrm{Ca}, \mathrm{Cu}, \mathrm{K}, \mathrm{Mg}, \mathrm{Mo}, \mathrm{Na}, \mathrm{P}, \mathrm{Zn}, \mathrm{Au}, \mathrm{Ba}$, $\mathrm{Hg}, \mathrm{Sr}, \mathrm{Ag}, \mathrm{Cd}, \mathrm{Pb}, \mathrm{Sn}, \mathrm{Br}, \mathrm{I}, \mathrm{Nb}, \mathrm{Sb}, \mathrm{W}, \mathrm{Ce}, \mathrm{Dy}$, Er, Eu, Gd, Ho, La, Lu, Nd, Pr, Sm, Tb, Tm, Yb. 
The factor analysis (FA) was performed also at aforementioned selected chemical elements. With FA, the characteristics of the individual elements were reduced to four synthetic variables (F1 to F4). The majority of analyzed elements (Al, As, $\mathrm{Ba}, \mathrm{Be}, \mathrm{Bi}, \mathrm{Co}, \mathrm{Cr}, \mathrm{Cs}, \mathrm{Fe}, \mathrm{Ga}, \mathrm{Ge}, \mathrm{Hf}, \mathrm{In}, \mathrm{Li}, \mathrm{Ni}$, $\mathrm{Rb}, \mathrm{Sc}, \mathrm{Sr}, \mathrm{Ta}, \mathrm{Te}, \mathrm{Tl}, \mathrm{V}, \mathrm{Y}, \mathrm{Zr}$, lanthanides and platinum group metals) were conducted to $\mathrm{F} 1$, and

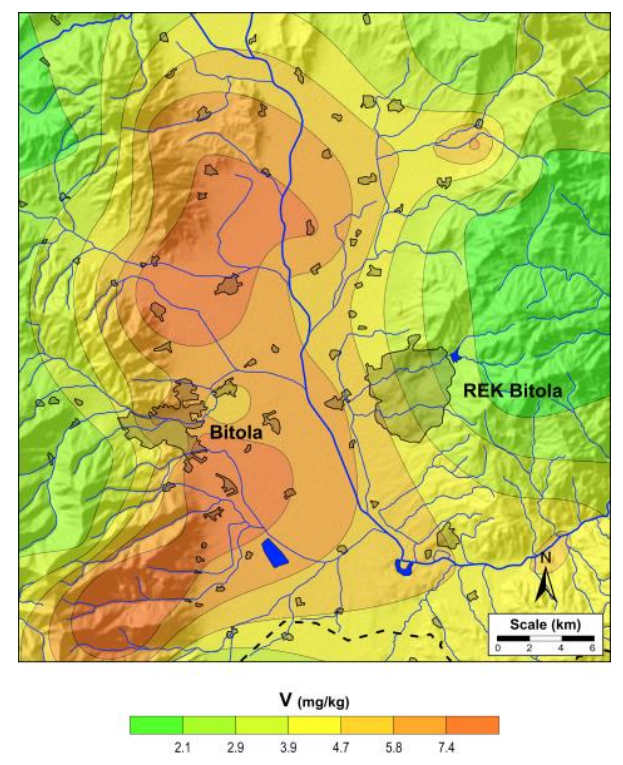

Figure 41. Spatial distribution of vanadium [110]

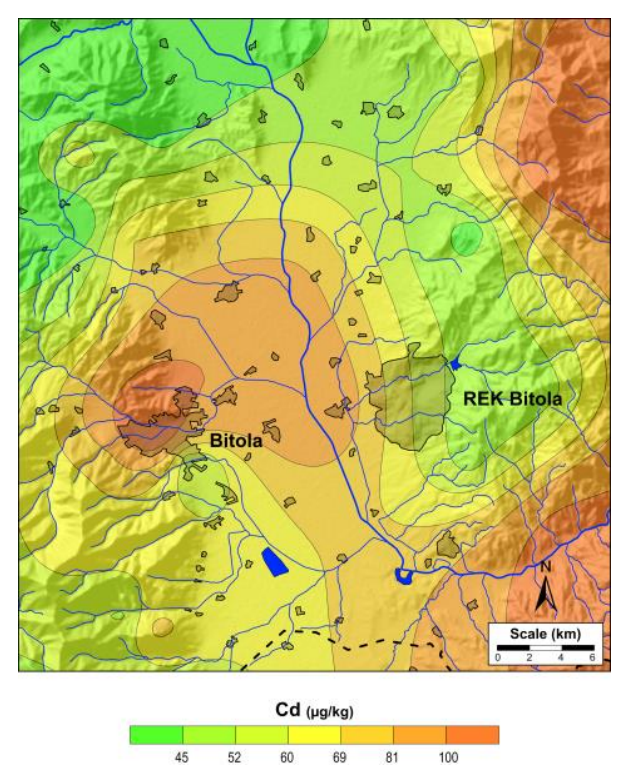

Figure 43. Spatial distribution of cadmium [110]

Factor $4(\mathrm{Nb}, \mathrm{Sb}, \mathrm{W})$ also illustrates the natural distribution pattern. High concentrations of these elements were found at higher altitudes of WestMacedonian Massif and Pelagonian Massif. This specific distribution was conducted to the relatively in the same time they represent the dominant chemical characteristic of the investigated area. The highest concentrations of this geochemical group occupy the western edge of Pelagonia close to the West-Macedonian Massif, which were primarily $\mathrm{Pz}$ rock. Vanadium was a leading element illustrating the spatial distribution of whole geochemical association (Figure 41).

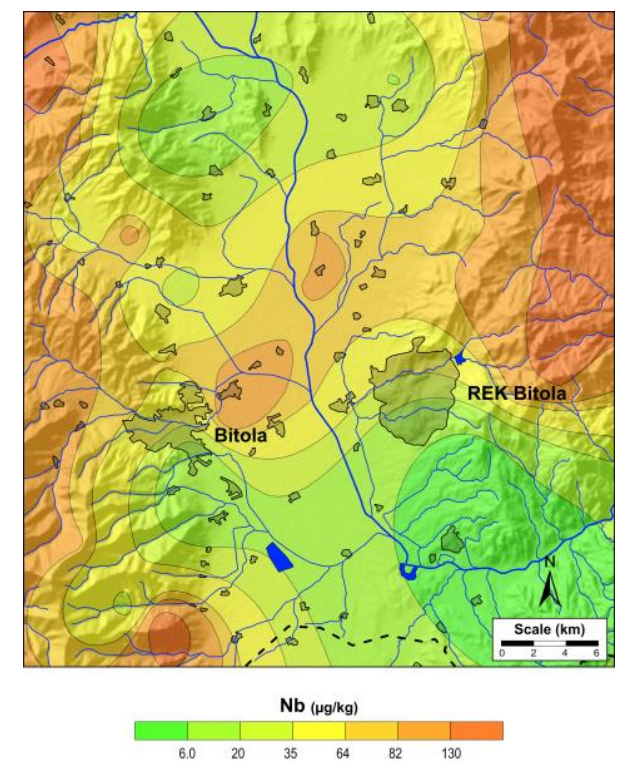

Figure 42. Spatial distribution of niobium [110]

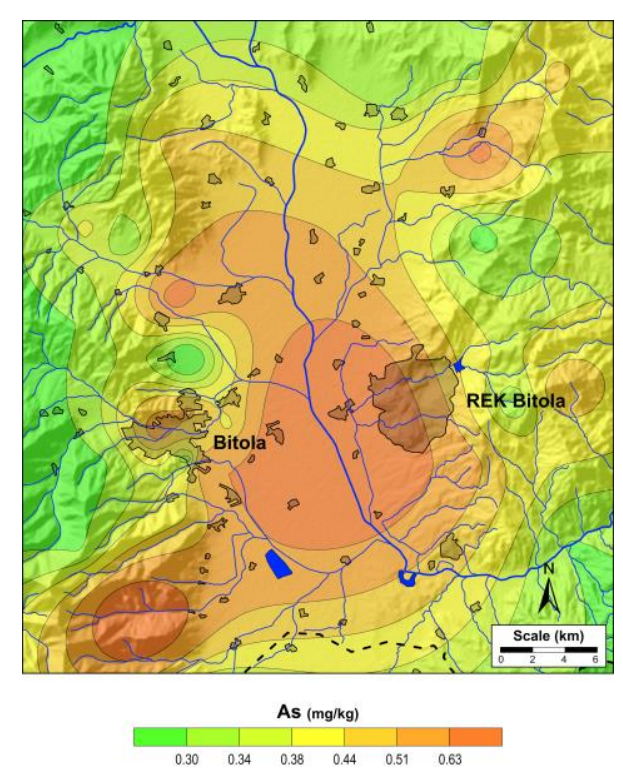

Figure 44. Spatial distribution of arsenic [110]

resistant rocks, such as $\mathrm{Pz}$ and $\mathrm{Pt}$ granite and less in $\mathrm{Pt}$ gneiss, found on both areas (W and $\mathrm{N}$ part). The distribution of this geochemical association was linked to areas with poor weathering, where the material remained "in situ", elements accumulated 
in initial soil or in distric rankers that were not transported. It seems that dust particles were more grained (silty or sandy) which this group makes less affected by the winds. This assumption was supported by fact that their high concentrations were not in the Pelagonia basin. Niobium, as a leading element, illustrates the best spatial distribution of the whole geochemical group (Figure 42).

Typical anthropogenic association is represented by Factor 2 ( $\mathrm{Ag}, \mathrm{Cd}, \mathrm{Cu}, \mathrm{Hg}, \mathrm{Pb}, \mathrm{Sn}, \mathrm{Zn})$. High contents of these elements were related to the wider area of Bitola. The highest concentrations were found in the center of the town, but they decreased with distance of the pollution source. At first glance, it might be assumed that high concentrations have natural origin, but previous studies have demonstrated that they are a result of remote transport [112]. This transport was influenced by dominant $\mathrm{W}$ and $\mathrm{NW}$ winds and precipitation. It was obvious that the distribution was not affected by open pit coal mining and thermoelectric power plant (REK Bitola). Cadmium may be a leading element that illustrates the spatial distribution of the whole association (Figure 43). The second anthropogenic geochemical association, isolated with Factor 3, combines B, Ca, K, Mg, Na, and P. Areola of high values was mainly found in Pelagonia basin, which was an area of intensive agriculture activities. High concentrations of K and P [110] are most probably a consequence of the use of fertilizers [37]. It can be concluded that the whole group results from their use.

The operation of the open pit brown coal and thermoelectric power plant (REK Bitola) was illustrated by distribution of As (Figure 44). According to the results of multivariate statistical analyses, this element was showing high correlation coefficients with elements of F1 (natural distribution). Arsenic was isolated, because in the West Balkan (particularly former Yugoslavia) the Neogen coal beds were enriched with $\mathrm{U}$ and mostly with As [35, $41,113]$. To investigate the anthropogenic influence in the studied area special attention was given to the behavior of As that was present mostly as a consequence of coal mining activities and later as a result of its burning in the thermoelectrical power plant. Compared with the other Balkan countries and Macedonia [36], Bitola had the highest values for As confirming that its presence is due to the coal processing in the thermoelectrical plant near Bitola. This is also confirmed by the spatial distribution of arsenic where it can be seen that the highest contents of arsenic are precisely in the moss samples collected near the power plant and fly ash landfill (Figure 44).

\section{Distribution of lead and zinc in soil over the Bitola region}

The purpose of this research was to detect the level of soil contamination with heavy metals especially with $\mathrm{Pb}$ and $\mathrm{Zn}$ in the Bitola region [114]. This was done to assess the impact of thermoelectrical power plant "Bitola" situated near the town of Bitola, as well as of traffic and industrial facilities in the town and its environs. Soil samples (topsoil and subsoil) were taken according to network and prepared for the analysis. Lead and zinc were determined by the application of inductively coupled plasma - atomic emission spectrometry (ICP-AES).

The investigated area covers $1400 \mathrm{~km}^{2}$ with 58 sampling locations (Figure 40). From each location 2 samples were taken in 2010: sample from the surface layer of soil - topsoil $(0-5 \mathrm{~cm})$ and deep soil layer - subsoil $(20-30 \mathrm{~cm})$.

The contents of $\mathrm{Zn}$ in soil samples from the territory of Bitola and its environs vary between 3.4 $\mathrm{mg} \mathrm{kg}^{-1}$ and $220 \mathrm{mg} \mathrm{kg}^{-1}$ with the median value of $26 \mathrm{mg} \mathrm{kg}^{-1}$, and for $\mathrm{Pb}$ vary between $2.1 \mathrm{mg} \mathrm{kg}^{-1}$ and $130 \mathrm{mg} \mathrm{kg}^{-1}$ with the median value of $11 \mathrm{mg}$ $\mathrm{kg}^{-1}$. From the obtained results it can be noticed that the element contents undergo with the geology of the region. However, it can be also concluded that these two elements are affected by anthropogenic influence from the thermoelectric power plant, high frequency traffic and industrial activities in the town of Bitola. Thus, higher content of $\mathrm{Pb}$ and $\mathrm{Zn}$ is visible around the town of Bitola and thermoelectric power plant (Figures 45, 46). It is particularly important that the influence of $\mathrm{Zn}$ in topsoil is related with the activity of thermoelectric power plant in this area (anthropogenic deviation) (Figure 45) and probably the influence of $\mathrm{Pb}$ in the town center is conducted with traffic and some activities in the town (Figure 46). From Figure 46 the influence of thermoelectric power plant can be also seen, because in this areola lead has high concentrations. It should be added that the content of $\mathrm{Pb}$ in topsoil is 1.4 time higher than in the subsoil confirming the anthropogenetic influence on the surface soil.

In this study the maximum value for $\mathrm{Pb} 130$ $\mathrm{mg} / \mathrm{kg}$ is 1.5 times higher than target value $(85 \mathrm{mg}$ $\mathrm{kg}^{-1}$ ) from (http://www.contaminatedland.co.uk/stdguid/dutch-1.htm) The New Dutch List for soil and 4 times lower than the intervention value $\left(530 \mathrm{mg} \mathrm{kg}^{-1}\right)$. $\mathrm{Zn}$ has the same behaviour, its maximum value of $220 \mathrm{mg} \mathrm{kg}^{-1}$ is 1.6 times higher than the target value $\left(140 \mathrm{mg} \mathrm{kg}^{-1}\right)$ and 3.3 times lower than the intervention value $\left(720 \mathrm{mg} \mathrm{kg}^{-1}\right)$. Higher values of zinc appear also on the south-western part of the 
studied area which is probably due to the lithogenic origin of higher content of zinc in the Paleozoic granatoides [115]. The highest contents for $\mathrm{Pb}$ and $\mathrm{Zn}$ were found in the town center confirming that pollution with these elements comes from the traffic and activities in the town center and fly ash from the thermoelectric power plant.

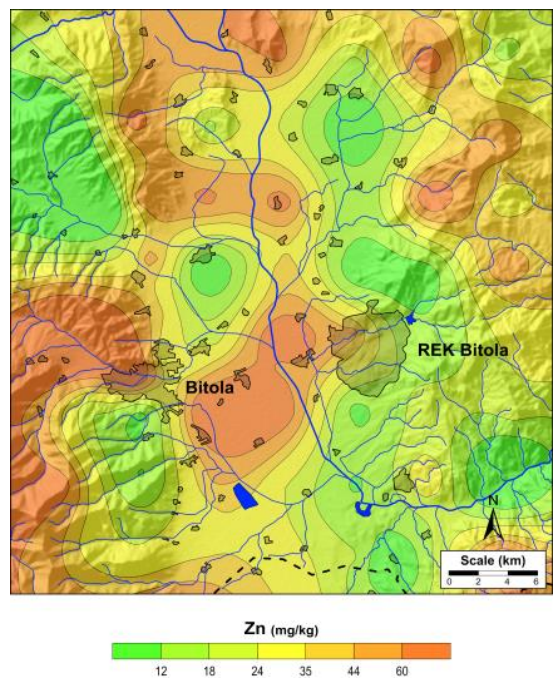

Figure 45. Spatial distribution of zinc [114]

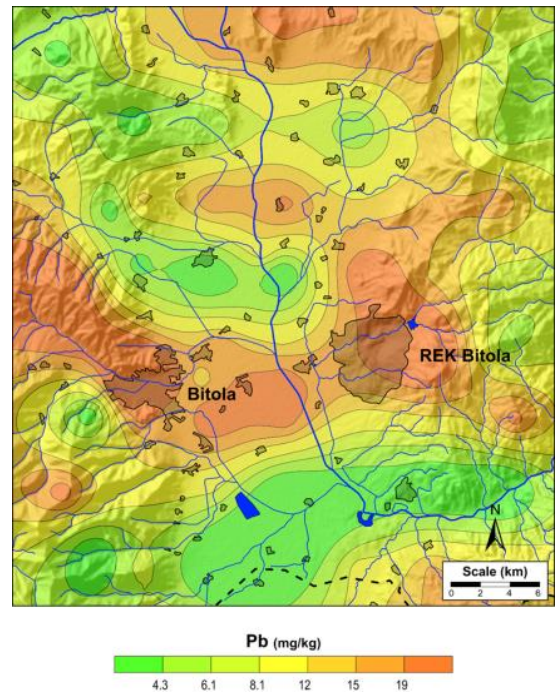

Figure 46. Spatial distribution of lead [114]

\section{Geochemical properties of topsoil around the open coal mine and Oslomej thermoelectric power plant, near Kičevo}

Kičevo is settled in the valley of Kičevo in the south-eastern foothills of Bistra Mountain in the western part of Macedonia. Kičevo is an important industrial centre in this part of Macedonia, due to the iron mine in Tajmište (closed at the moment), the coal mine and the thermoelectric power plant REK "Oslomej". It is the first facility of this kind built in the country. REK "Oslomej" has the installation capacity of $125 \mathrm{MW}$ with net annual production of around $700 \mathrm{GWh}$. REK Oslomej began its production in 1980 and has had excellent production results. It provides for about $9 \%$ of the total electrical energy production in the Republic of Macedonia.

The aim of this study is to present the results of a first systematic investigation of spatial distribution of various chemical elements in surface soil in the Kičevo region and to assess the influence of the mine and thermoelectrical power plant. The study area of $148 \mathrm{~km}^{2}$ (Figure 47) is covered by a sampling grid of $2 \times 2 \mathrm{~km}$ but in the urban zone of Kičevo and around the Oslomej thermoelectric power plant the sampling grid is denser, $1 \times 1 \mathrm{~km}$. Altogether 52 soil samples were collected in 2008. In each sampling point soil samples were collected as topsoil $(0-5 \mathrm{~cm})$. ICP-AES was applied for the determinations of 18 elements (Al, As, $\mathrm{Ba}, \mathrm{Ca}, \mathrm{Cd}, \mathrm{Co}$, $\mathrm{Cr}, \mathrm{Cu}, \mathrm{Fe}, \mathrm{K}, \mathrm{Li}, \mathrm{Mg}, \mathrm{Mn}, \mathrm{Na}, \mathrm{Ni}, \mathrm{Pb}, \mathrm{Sr}$ and $\mathrm{Zn}$ ).

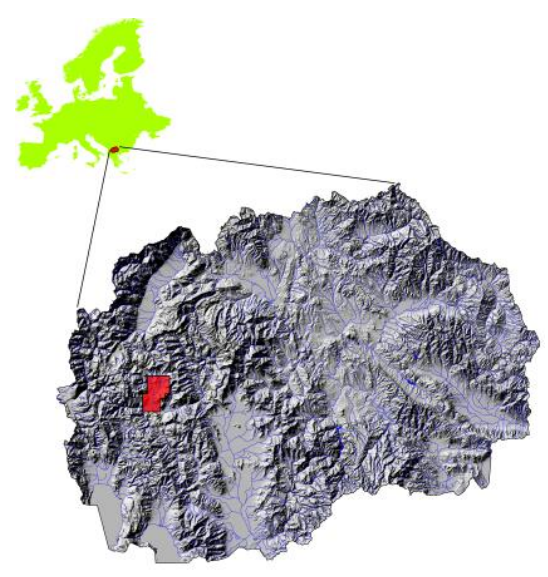

Figure 47. Location of the study area [116]

Based on factor analyses three natural geogenic associations of elements were defined (Figure 48): Cr-Ni-Li-Co-Fe-As, Al-Ca-Mg-Sr and Ba-K$\mathrm{Cu})[116,117]$. Similarly with the results from the study of the Bitola region, even the distributions of typical heavy metals such as $\mathrm{Pb}, \mathrm{Zn}$ and $\mathrm{Cd}$, which are not isolated as an anthropogenic geochemical association by multivariate statistical methods, still show some trends of local anthropogenic enrichment (Figure 49). First of all, the distribution of $\mathrm{Pb}$ is not only influenced by the open coal pit "Oslomej" thermal power plant, but also by river transportation processes from the "Tajmište" iron mine into alluvial sediments of the Zajaska river. The distribution of $\mathrm{Zn}$ is influenced by the Metal 
Industry Kičevo operation and atmospheric transport. Their absolutely anthropogenic tendency is present, however, comparing their average values with European averages, as they exceed these by 3 or 4 times. When considering their spatial distributions (Figure 49) it is necessary to observe more factors: (1) impact of the coal open pit and the "Oslomej" thermal power plant, (2) leaching from the "Tajmište" abandoned mine and a subsequent deposition of heavy metals in the alluvial sediments of the Zajaska river, and (3) impact of Metal Industry Kičevo.

Based on the result of spatial distribution and average values of $\mathrm{Cd}$ (Figure 49) in the aforementioned groups, we can not see the anthropogenic impact. Namely, the average concentrations of $\mathrm{Cd}$ along the Zajaska river and Oslomej are up to 50\% higher than the background values.
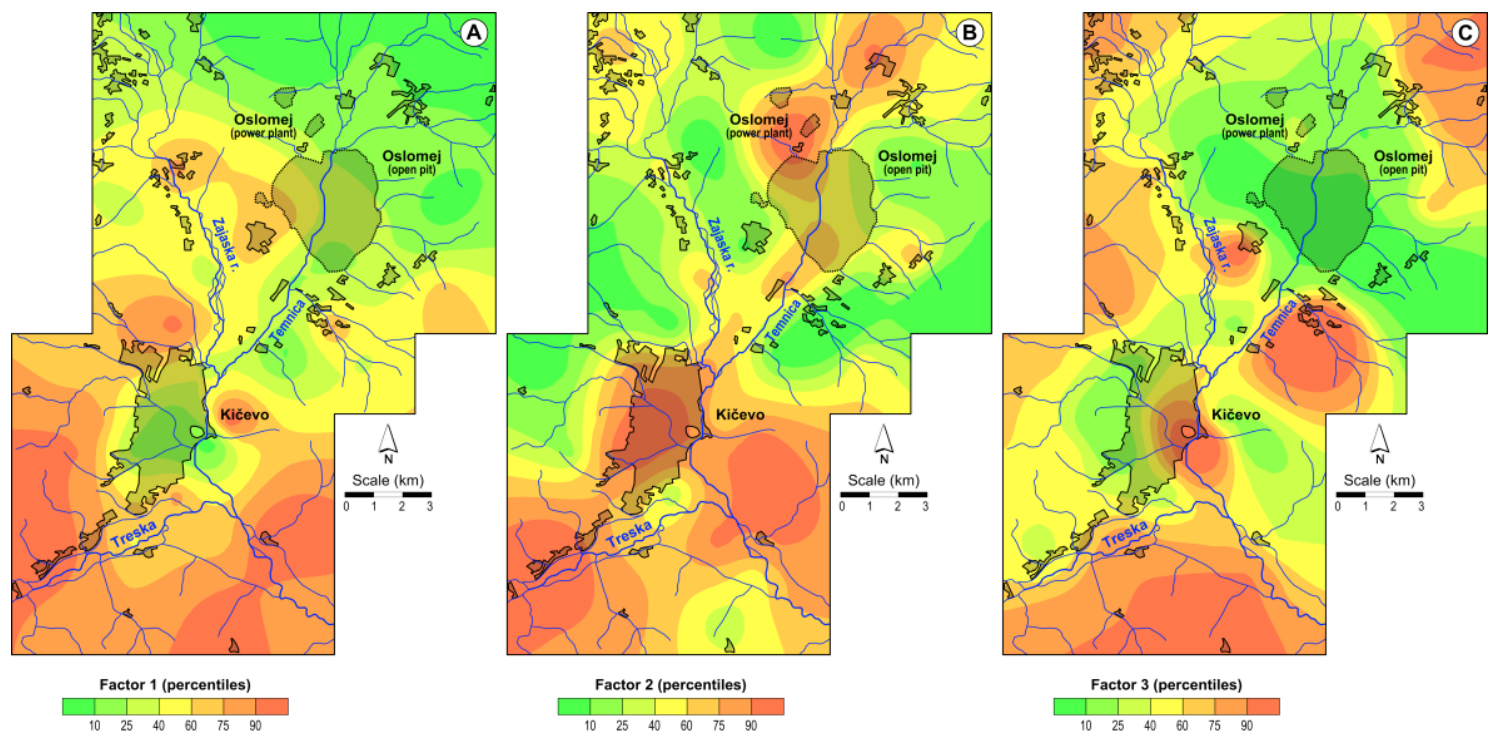

Figure 48. Spatial distribution of Factor scores: A - Factor 1 (Cr, Ni, Li, Co, Fe and As); $\mathrm{B}$ - Factor 2 (Ca, Sr, $\mathrm{Mg}$ and $\mathrm{Al}$ ); C - Factor 3 (Ba, K and $\mathrm{Cu}$ ) [117]
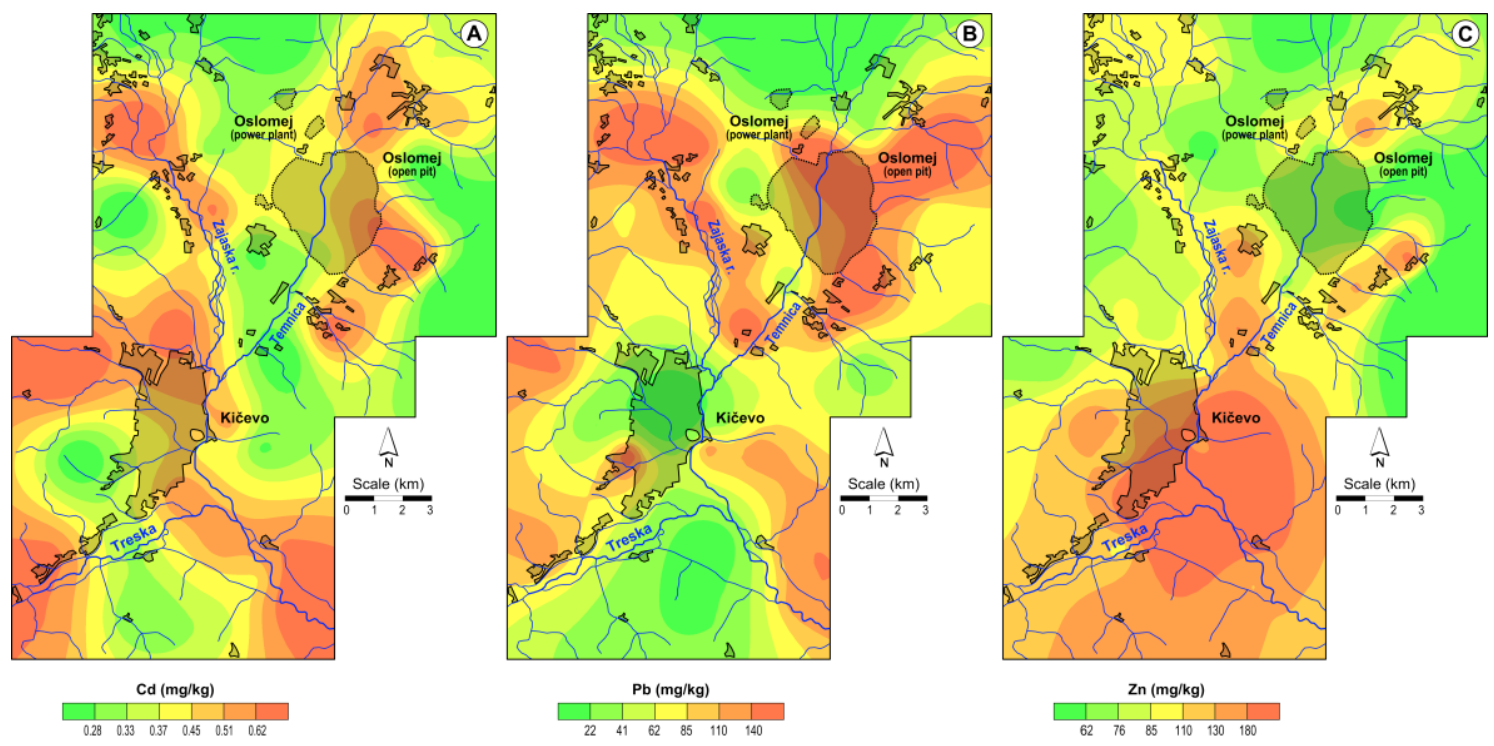

Figure 49. Spatial distribution of anthropogenic introduced elements: (cadmium - A, lead - B, zinc - C) [117]

Some weak anthropogenic trends are noticed, but they are hidden by some background fluctuations because the surrounding Paleozoic rocks are enriched with this element. It is a completely different case with the distribution of $\mathrm{Pb}$ (Figure 48).
The results show highly significant differences between the average background values $\left(64 \mathrm{mg} \mathrm{kg}^{-1} \mathrm{~Pb}\right.$ in range $1.7-220 \mathrm{mg} \mathrm{kg}^{-1}$ ), along the river Zajaska (170 mg kg ${ }^{-1} \mathrm{~Pb}$, in range $120-220 \mathrm{mg} \mathrm{kg}^{-1}$ ), and in the area to the east of the "Oslomej" open pit (200 
$\mathrm{mg} \mathrm{kg}-1 \mathrm{~Pb}$, in range 110 to $\left.430 \mathrm{mg} \mathrm{kg}^{-1}\right)$. The aforementioned values exceed the target ones but are still lower than intervention values (New Dutch List). A halo dispersion pattern with high values of $\mathrm{Pb}$ occurs east of the open pit in accordance with the dominant wind direction and wind intensity and can be attributed exclusively to atmospheric transport and deposition.

The average values of $\mathrm{Zn}$ among the background samples show quite significant differences (94 $\mathrm{mg} \mathrm{kg}^{-1}$ of $\mathrm{Zn}$, in range $110-230 \mathrm{mg} \mathrm{kg}^{-1}$ ) in the group of samples collected in the urban area of Kičevo (320 mg kg-1 of $\mathrm{Zn}$, in range $130-1700$ $\mathrm{mg} \mathrm{kg}^{-1}$ ). The average values of $\mathrm{Zn}$ exceed the target values and even, at some sampling sites, the intervention values determined by the New Dutch List. In this case there is a clear anthropogenic influence on the contamination halo, and high concentrations of $\mathrm{Zn}$ are consequences of the metal processing industry in Kičevo. This assumption is proven by the position and shape of the contamination aureole, as well as by the wind direction. Comparison with the distribution of $\mathrm{Pb}$ indicates that this contamination halo solely depends on atmospheric transport.

\section{REFERENCES}

[1] A. Kabata-Pendias, H. Pendias, Trace Elements in Soil and Plants, 3rd edn., CRC Press, Boca Raton, 2001.

[2] T. Godish, Air Quality. 4th edition, Lewis Publishers, Boca Raton, 2004.

[3] W. J. Gauderman, E. Avol, F. Gilliland, H. Vora, D. Thomas, K. Berhane, R. McConnell, N. Kuenzli, F. Lurmann, E. Rappaport, H. Margolis, D. Bates, J. Peters, The effect of air pollution on lung from 10 to 18 years of age, The New England Journal of Medicine, 351 (2004), pp. 1057-1067.

[4] D. Vallero, Fundamentals of Air Pollution. $4^{\text {th }}$ edition, Academic Press Elsevier, Amsterdam, 2008.

[5] M. Athar, S. Vohora, Heavy Metals and Environment, New International, Wiley Eastern, New Delhi, 1995.

[6] A. Avila, A. Rodrigo, Trace metal fluxes in bulk deposition, through fall and stemflow at two evergreen oak stands in NE Spain subject to different exposure to the industrial environment, Atmos. Environ., 38 (2004), pp. 171-180.

[7] H. Hou, T. Takamatsu, M. K. Koskiwa, M. Hosomi, Trace metal sin bulk precipitation and through fall in a suburban area of Japan, Atmos. Environ., 39 (2005), pp. 3583-3595.

[8] R. Šajn, Distribution of mercury in surface dust and topsoil in Slovenian rural and urban areas,
RMZ - Geology and Geoenvironment, 51 (2004), pp. 1800-1803.

[9] L. Borůvka, O. Vacek, J. Jehlička, Principal component analysis as a tool to indicate the origin of potentially toxic elements in soils, Geoderma, 128, (2005), pp. 289-300.

[10] F. Bretzel, M. Calderisi, Metal contamination in urban soils of coastal Tuscany (Italy), Environ. Monit. Assess., 118 (2006), pp. 319-335.

[11] M. M. Diawara, J. S. Litt, D. Unis, N. Alfonso, L. A. Martinez, J. G. Crock, D. B. Smith, J. Carsella, Arsenic, cadmium, lead, and mercury in surface soils, Pueblo, Colorado: implications for population health risk, Environ. Geochem. Health, 28 (2006), pp. 297-315.

[12] C. M. Davidson, G. J. Urquhart, F. Ajmone-Marsan, M. Biasioli, A. D. Duarte, E. Diaz-Barrientos, H. Grcman, L. Hossack, A. S. Hursthouse, L. Madrid, S. Rodrigues, M. Zupan, Fractionation of potentially toxic elements in urban soils from five European cities by means of a harmonised sequential extraction procedure, Anal. Chim. Acta, 565 (2006), pp. 63-72.

[13] A. Demetriades, X. Li, M. H. Ramsey, I. Thornton, Chemical speciation and bioaccessibility of lead in surface soil and house dust, Lavrion urban area, Attiki, Hellas, Environ. Geochem. Health, 32 (2010), pp. 529-552.

[14] J. Alijagić, R. Šajn, Distribution of chemical elements in an old metallurgical area, Zenica (Bosnia and Herzegovina), Geoderma, 162 (2011), pp. 7185.

[15] T. Stafilov, R. Šajn, Z. Pančevski, B. Boev, M. V. Frontasyeva, L. P. Strelkova, Heavy metal contamination of surface soils around a lead and zinc smelter in the Republic of Macedonia, $J$. Hazard. Mater., 175 (2010), pp. 896-914.

[16] T. Stafilov, R. Šajn, B. Boev, J. Cvetkovič, D. Mukaetov, M. Andreevski, S. Lepitkova, Distribution of some elements in surface soil over the Kavadarci region, Republic of Macedonia, Environ. Earth Sci., 61 (2010), pp. 1515-1530.

[17] I. Razo, L. Carrizales, J. Castro, F. Diaz-Barriga, M. Monroy, Arsenic and heavy metal pollution of soil, water and sediments in a semi-arid climate mining area in Mexico, Water Air Soil Poll., 152 (2004), pp. 129-152.

[18] R. K. Aryal, M. Murakami, H. Furumai, F. Nakajima, H. K. P. K. Jinadasa, Prolonged deposition of heavy metals in infiltration facilities and its possible threat to groundwater contamination, Water Sci. Technol., 54 (2006), pp. 205-212.

[19] S. Baron, J. Carignan, A. Ploquin, A., Dispersion of heavy metals (metalloids) in soils from 800year-old pollution (Mont-Lozere, France), Environ. Sci. Technol., 40 (2006), pp. 5319-5326.

[20] V. Cappuyns, R. Swennen, A. Vandamme, M. Niclaes, Environmental impact of the former $\mathrm{Pb}-\mathrm{Zn}$ 
mining and smelting in East Belgium, J. Geochem. Explor., 88 (2006), pp 6-9.

[21] J. Li, Z. M. Xie, Y. G. Zhu, R. Naidu, Risk assessment of heavy metal contaminated soil in the vicinity of a lead/zinc mine, J. Environ. Sci. China, 17 (2005), pp. 881-885.

[22] Y. Li, Y. B. Wang, X. Gou, Y. Su, G. Wang, Risk assessment of heavy metals in soils and vegetables around non-ferrous metals mining and smelting sites, Baiyin, China, J. Environ. Sci. China, 18 (2006), pp. 1124-1134.

[23] C. Pruvot, F. Douay, F. Herve, C. Waterlot, Heavy metals in soil, crops and grass as a source of human exposure in the former mining areas, $J$ Soil Sediment, 6 (2006), pp. 215-220.

[24] B. Hock, M. Seifert, Biomonitoring, a new challenge for measuring and testing, Manage. Environ. Qual. Int. J., 14 (2003), pp. 279-292.

[25] R. Blagnyte, D. Paliulis, Research into heavy metals pollution of atmosphere applying moss as bioindicator: A literature review, Environ. Res. Eng. Manage., 54 (2010), pp. 26-33.

[26] A. Z. Glukhov, S. I. Prokhorova, Morphological variability of the brome grass: application for nonspecific biomonitoring of urban anthropogenic impact, Acta Environ. Univ. Comenianae Bratislava, 19 (2011), pp. 76-81.

[27] J. W. S. Longchurst, C. A. Brebbia (Eds.), Air Pollution, XXI, WIT Press, Southampton, UK, 2013.

[28] H. Harmens, D. A. Norris, E. Steinnes, E. Kubin, J. Piispanen, R. Alber, Y. Aleksiayenak, O. Blum, M. Coşkun, M. Dam, L. de Temmerman, J. A. Fernández, M. Frolova, M. Frontasyeva, L. González-Miqueo, K. Grodzińska, Z. Jeran, S. Korzekwa, M. Krmar, K. Kvietkus, S. Leblond, S. Liiv, S. H. Magnússon, B. Maňkovská, R. Pesch, Å. Rühling, J. M. Santamaria, W. Schröder, Z. Spiric, I. Suchara, L. Thöni, V. Urumov, L. Yurukova, H. G. Zechmeister, Mosses as biomonitors of atmospheric heavy metal deposition: Spatial patterns and temporal trends in Europe, Environ. Poll., 158 (2010), pp. 3144-3156.

[29] B. A. Markert, A. M. Breure, H. G. Zechmeister, Definitions, Strategies, and Principles for Bioindication/Biomonitoring of the Environment, Elsevier Press, Oxford, 2003, pp. 3-39.

[30] Å. Rühling, G. Tyler, An ecological approach to the lead problem, Botaniska Notiser, 122 (1968), pp. 248-342.

[31] H. G. Zechmeister, K. Grodzinska, G. SzarekQukaszewska, Bryophytes, in: B. A. Markert, A. M. Breure, H. G. Zechmeister (Eds.), Bioindicators and Biomonitors, Elsevier Science Ltd., Amsterdam, 2003, pp. 329-375.

[32] H. Harmens, D. Norris, G. Mills, \& the participants of the moss survey, Heavy Metals and Nitrogen in Mosses: Spatial Patterns in 2010/2011 and Long-Term Temporal Trends in Europe, ICP Vegetation Programme Coordination Centre, Centre for Ecology and Hydrology, Bangor, UK, 2013, $63 \mathrm{pp}$.

[33] H. Harmens, I. Ilyin, G. Mills, J. R. Aboal, R. Alber, O. Blum, M. Coşkun, L. de Temmerman, J. A. Fernández, R. Figueira, M. Frontasyeva, B. Godzik, N. Goltsova, Z. Jeran, S. Korzekwa, E. Kubin, K. Kvietkus, S. Leblond, S. Liiv, S. H. Magnússon, B. Maňkovská, O. Nikodemus, R. Pesch, J. Poikolainen, D. Radnović, Å. Rühling, J. M. Santamaria, W. Schröder, Z. Spiric, T. Stafilov, E. Steinnes, I. Suchara, G. Tabors, L. Thöni, G. Turcsányi, L. Yurukova, H. G. Zechmeister, Country-specific correlations across Europe between modelled atmospheric cadmium and lead deposition and concentrations in mosses, Environ. Poll., 166 (2012), pp. 1-9.

[34] L. Barandovski, M. Cekova, M. V. Frontasyeva, S. S. Pavlov, T. Stafilov, E. Steinnes, V. Urumov, Air Pollution Studies in Macedonia Using the Moss Biomonitoring Technique, NAA, AAS and GIS Technology; Preprint E18-2006-160, Joint Institute for Nuclear Research, Dubna, 2006.

[35] L. Barandovski, M. Cekova, M. V. Frontasyeva, S. S. Pavlov, T. Stafilov, E. Steinnes, V. Urumov, Atmospheric deposition of trace element pollutants in Macedonia studied by the moss biomonitoring technique, Environ. Monitor. Assess., 138 (2008), pp. 107-118.

[36] L. Barandovski, M. V. Frontasyeva, T. Stafilov, R. Šajn, S. Pavlov, V. Enimiteva, Trends of atmospheric deposition of trace elements in Macedonia studied by the moss biomonitoring technique, $J$. Environ. Sci. Health A, 47 (2012), pp. 2000-2015.

[37] L. Barandovski, T. Stafilov, R. Šajn, M. V. Frontasyeva, K. Bačeva, Air pollution study in Macedonia by using moss biomonitoring technique, ICP-AES and AAS, Maced. J. Chem. Chem. Eng., 32(1) (2013), pp. 89-107.

[38] K. Bačeva, T. Stafilov, R. Šajn, Biomonitoring of nickel air pollution near the city of Kavadarci, Republic of Macedonia, Ecol. Prot. Environ., 12(1-2) (2009), pp. 57-69.

[39] K. Bačeva, T. Stafilov, R. Šajn, C. Tănăselia, S. Ilić Popov, Distribution of chemical elements in attic dust in the vicinity of ferronickel smelter plant, Fresenius Environ. Bull., 20(9) (2011), pp. 2306-2314.

[40] K. Bačeva, T. Stafilov, R. Šajn, C. Tănăselia, Moss biomonitoring of air pollution with heavy metals in the vicinity of a ferronickel smelter plant, J. Environ. Sci. Health A, 47(4) (2012), pp. 645-656.

[41] P. Lazarov, T. Serafimovski, Ore Deposits and Occurences of Energy Raw Materials in the Republic of Macedonia, Faculty of Mining and Geology, Štip, 1997, pp. 89-91 (in Macedonian). 
[42] T. Stafilov, L. Peeva, B. Nikov, A. de Koning, Industrial hazardous waste in the Republic of Macedonia, Applied Environmental Geochemistry - Anthropogenic Impact on Human Environment in the SE Europe, Proceedings Book (R. Šajn, G. Žilbert, J. Alijagić, Eds.), Ljubljana, 2009, ISBN 978-961-6498-18-0, pp. 108-112.

[43] T. Stafilov, R. Šajn, Z. Pančevski, B. Boev, M. V. Frontasyeva, L. P. Strelkova, Geochemical Atlas of Veles and the Environs, Faculty of Natural Sciences and Mathematics, Skopje, 2008.

[44] Z. Pančevski, T. Stafilov, M. V. Frontasyeva, Copper in surface soil of Veles region, Macedonia, Geologica Macedonica, 20 (2006), pp. 27-32.

[45] R. Salminen, M. J. Batista, M. Bidovec, A. Demetriades, B. de Vivo, W. de Vos, M. Duris, A. Gilucis, V. Gregorauskiene, J. Halamic, P. Heitzmann, G. Jordan, G. Klaver, P. Klein, J. Lis, J. Locutura, K. Marsina, A. Mazreku, P. J. O’Connor, S. Å. Olsson, R. T. Ottesen, V. Petersell, J. A. Plant, S. Reeder, I. Salpeteur, H. Sandström, U. Siewers, A. Steenfelt, T. Tarvainen, Geochemical Atlas of Europe. Part 1, Background Information, Methodology and Maps, Geological Survey of Finland, Espoo, 2005.

[46] Z. Pančevski, T. Stafilov, K. Bačeva, Distribution of heavy metals in some vegetables grown in the vicinity of lead and zinc smelter plant, Contribution, Sec. Nat. Math. Biotech. Sci., MASA, 35(1), (2014), pp. 25-36.

[47] Z. Pančevski, T. Stafilov, K. Bačeva, Distribution of heavy metals in lettuce and carrot produced in the vicinity of lead and zinc smelter plant, Int. $J$. Pure Appl. Chem., 9 (2014), pp. 1-10.

[48] Z. Nikolovski, Polluted Macedonian city to be rid of smelter, SE European Times, 2008; http://www.setimes.com/cocoon/setimes/xhtml/en _GB/features/setimes/features/2008/05/01/feature03

[49] M. Kochubovski, Blood-lead levels in schoolchildren from Veles, related to the ambient air pollution by lead, exposure and risk assessment of chemical pollution - contemporary methodology, In: NATO Science for Peace and Security, Series C: Environmental Security, pp. 371-378, Springer, Heidelberg, 2009.

[50] A. Lazarevski, Climate in Macedonia, Kultura, Skopje, 1993 (in Macedonian)

[51] V. Jordanovska, T. Stafilov, Determination of lead and zinc in vegetables produced in the area near lead and zinc smelting plant in Titov Veles, Macedonia, Third International Symposium and Exhibition on Environmental Contamination in Central and Eastern Europe, Warsaw, Symposium Proceedings, pp. 70-72, 1996.

[52] T. Stafilov, V. Jordanovska, Determination of cadmium in some vegetables produced in the area near the lead and zinc smelting plant in Veles, Macedonia, Ekol. Zašt. Život. Sred., 4 (1997), pp. 35-38.

[53] Regulations for the general requirements for food safety, Official Journal of the Republic of Macedonia No. 118, December 30, 2005, pp. 250-251.

[54] Regulation on quantities of pesticides and other toxic substances, hormones, antibiotics and mycotoxins that can be found in animal foods, Official Journal of SFRY, No. 59, November 18, 1983.

[55] T. Stafilov, R. Šajn, B. Boev, J. Cvetkovič, D. Mukaetov, M. Andreevski, Geochemical Atlas of Kavadarci and the Environs, Faculty of Natural Sciences and Mathematics, Skopje, 2008.

[56] T. Stafilov, R. Šajn, J. Alijagić, Distribution of arsenic, antimony and thallium in soil in Kavadarci and its environs, Republic of Macedonia, Soil Sediment Contam. Int. J., 22 (2013), pp. 105-118.

[57] Nickel Smelting and Refining, Pollution Prevention and Abatement Handbook, World Bank Group, 1998, pp. 349-352.

[58] B. Boev, J. Živanović, S. Lipitkova, Selenium and other trace elements in the soil of the Tikveš region, Proceedings on the $3^{\text {rd }}$ International Workshop on the Anthropogenic Effects on the Human Environment in the Tertially Basins in the Mediterranean (B. Boev, T. Serafimovski, Eds.), Štip, pp. 23-35, 2005.

[59] Z. Maksimović, Mineralogical Study of the Ore from Ržanovo Mine, Faculty of Geology and Mining, Belgrade, 1982.

[60] Gj. Filipovski, Soils Degradation as a Component of the Environment in the Republic of Macedonia, Macedonian Academy of Sciences and Arts, Skopje, 2003 (in Macedonian).

[61] B. Boev, S. Janković, Nickel and Nickeliferrous Iron Deposits of the Vardar Zone (SE Europe) with Particular References to the RžanovoStudena Voda Ore-bearing Series, Faculty of Mining and Geology, Special issue No. 3, Štip, 1996, pp. 103-126.

[62] S. Sayegh-Petkovšek, K. Kotnik, N. Kugonič, R. Šajn, M. Janža, Š. Kumelj, M. Šešerko, M. Zaluberšek, M. Bole, P. Druks Gajšek, M. Petrič, A. Košir, J. Kogovšek, H. Poličnik, M. Čater, T. Levanič, A. Bienelli-Kalpič, A. Čarni, M. Kostadinovski, P. Košir, V. Matevski, U. Šilc, I. Zelnik, I. Jelenko, A. Brancelj, D. Tome, K. Savinek, B. Mikuž, I. Miklavžina, D. Končnik, J. Flis, U. Repinc, M. Štrok, L. Benedik, S. Lojen, B. Črnič, S. Gobec, L. Ivanovski, B. Blaževski, A. Veljanovska, Z. Pavšek, B. Pokorny, Določitev vpliva vojaškega poligona Krivolak na okolje $z$ namenom njegove ekološke sanacije, Poročilo. ERICo Velenje, Velenje, 2007, pp. 590.

[63] R. Šajn, Distribution of chemical elements in attic dust and soil as reflection of lithology and anthro- 
pogenic influence in Slovenia, J. Phys., 10 (2003), pp. 1173-1176.

[64] R. Šajn, Factor analysis of soil and attic-dust to separate mining and metallurgy influence, Meza Valley, Slovenia, Math. Geol., 38 (2006), pp. 735-747.

[65] J. Alijagić, R. Šajn, Distribution of chemical elements in an old metallurgical area, Zenica (Bosnia and Herzegovina), Geoderma, 162 (2011), pp. 7185 .

[66] T. Stafilov, Z. Levkov, Preliminary assessment of the effects of pollution and water management on water quality in the Vardar river, Work Package 2 - Water Quality, Improvement of Management of Transboundary Water Resources. Project No. 3MAC01/10/104, European Agency for Reconstruction/Ministry of Environment and Physical Planning of the Republic of Macedonia, Skopje, 2007.

[67] T. Stafilov, T. Todorovski, B. Grozdanova, Lj. Spandževa, Determination of thallium in ore from Allchar by atomic absorption spectrometry, Nucl. Instr. Meth. Phys. Res. A, 271 (1988), pp. 321-323.

[68] B. Boev, V. Bermanec, T. Serafimovski, S. Lepitkova, S. Mikulcić, M. Soufek, G. Jovanovski, T. Stafilov, M. Najdoski, Allchar mineral assemblage, Geologica Macedonica, 15-16 (2001-2002), pp. 1-23.

[69] K. Bačeva, T. Stafilov, R. Šajn, C. Tănăselia, Distribution of chemical elements in soils and stream sediments in the area of abandoned Sb-AsTl Allchar mine, Republic of Macedonia, Environ. Res., 133, pp. 77-89 (2014).

[70] T. Stafilov, B. Balabanova, R. Šajn, K. Bačeva, Moss biomonitoring in use: Small scale area investigation for heavy metals air pollution Mines and smelter plant environs in the Republic of Macedonia, In: Moss: Classification, Development and Growth and Functional Role in Ecosystems, J. Mohamed (Ed.), Nova Science Publishers Inc., Hauppauge, NY, 2014, pp. 111-170.

[71] V. Ilacqua, N. C. Freeman, J. P. Fagliano, J. Lioy, The historical record of air pollution as defined by attic dust, Atmos. Environ., 37 (2003), pp. 2379-2389.

[72] A. M. Tye, E. S. Hodgkinson, B. G. Rawlins, Microscopic and chemical studies of metal particulates in tree bark and attic dust: evidence for historical atmospheric smelter emissions, Humberside, UK, $J$. Environ. Monit., 8 (2006), pp. 904-912.

[73] E. B. Culbard, I. Thornton, J. Watt, M. Wheatley, S. Moorcroft, M. Thompson, Metal contamination in British urban dusts and soils, J. Environ. Qual., 17 (1988), pp. 226-234.

[74] J. E. Fergusson, N. D. Kim, Trace elements in street and house dusts: Source and speciation, Sci. Total Environ., 100 (1991), pp. 125-150.

[75] M. S. Dundar, F. Ozdemir, Heavy metal contents of indoor airdust particulate matter from Adapa- zari, Turkey, Fresenius Environ. Bull., 14 (2005), pp. 189-193.

[76] K.-M. Ochsenkühn, M. Ochsenkühn-Petropoulou, Heavy metals in airborne particulate matter of an industrial area in Attica, Greece and their possible sources. Fresenius Environ. Bull., 17 (2008), pp. 455-462.

[77] R. Šajn, Geochemical Properties of Urban Sediments on the Territory of Slovenia, Geological Survey of Slovenia, Ljubljana, 1999, pp. 1-136.

[78] R. Šajn, Influence of lithology and antropogenic activity on distribution of chemical elements in dweling dust, Slovenia, Geologija, 43 (2000), pp. 85-101.

[79] R. Šajn, Using attic dust and soil for the separation of anthropogenic and geogenic elemental distributions in an old metallurgic area (Celje, Slovenia), Geochemistry, 5 (2005), pp. 59-67.

[80] T. Stafilov, R. Šajn, B. Balabanova, K. Bačeva, Distribution of heavy metals in attic and deposited dust in the vicinity of copper ore processing and ferronickel smelter plants in the Republic of Macedonia, In: Dust: Sources, Environmental Concerns and Control, L. B. Wouters, M. Pauwels (Eds.), Nova Science Publishers Inc., Hauppauge, NY, 2012, pp. 57-98.

[81] K. Bačeva, T. Stafilov, R. Šajn, Monitoring of air pollution with heavy metals in the vicinity of ferronickel smelter plant by deposited dust, Maced. J. Ecol. Environ., 1 (2012), pp. 47-57.

[82] R. Tsitouridou, C. Anatolaki, On the wet and dry deposition of ionic species in the vicinity of coalfired power plants, northwestern Greece, Atmos. Res., 83 (2007), pp. 93-105.

[83] L. Morselli, P. Olivieri, B. Brusori, F. Passarini, Soluble and insoluble fractions of heavy metals in wet and dry atmospheric depositions in Bologna, Italy. Environ. Poll., 124 (2003), pp. 457-469.

[84] A. Avila, A. Rodrigo, Trace metal fluxes in bulk deposition, through fall and stemflow at two evergreen oak stands in NE Spain subject to different exposure to the industrial environment, Atmos. Environ., 38 (2004), pp. 171-180.

[85] Z. Polkowska, A. Astel, B. Walna, S. Małek, K. Mędrzycka, T. Górecki, J. Siepak, J. Namieśnik, Chemometric analysis of rain water and through fall at several sites in Poland, Atmos. Environ., 39 (2005), pp. 837-855.

[86] T. Stafilov, B. Balabanova, R. Šajn, K. Bačeva, B. Boev, Geochemical Atlas of Radoviš and the Environs and the Distribution of Heavy Metals in the Air, Faculty of Natural Sciences and Mathematics, Skopje, 2010.

[87] B. Balabanova, T. Stafilov, R. Šajn, K. Bačeva, Spatial distribution and characterization of some toxic metals and lithogenic elements in topsoil and subsoil from copper mine environs, Int. J. Environ. Prot., 3 (2013), pp. 1-9. 
[88] B. Balabanova, T. Stafilov, K. Bačeva, R. Šajn, Atmospheric pollution with copper around the copper mine and flotation, Bučim, Republic of Macedonia, using biomonitoring moss and lichen technique, Geologica Macedonica, 23 (2009), pp. 35-41.

[89] B. Balabanova, T. Stafilov, K. Bačeva, R. Šajn, Biomonitoring of atmospheric pollution with heavy metals in the copper mine vicinity located near Radoviš, Republic of Macedonia, J. Environ. Sci. Health A, 45 (2010), pp. 1504-1518.

[90] B. Balabanova, T. Stafilov, R. Šajn, K. Bačeva, Distribution of chemical elements in attic dust as reflection of lithology and anthropogenic influence in the vicinity of copper mine and flotation, Arch. Environ. Contam. Toxicol., 61 (2011), pp. 173-184.

[91] B. Balabanova, T. Stafilov, R. Šajn, K. Bačeva, Total deposited dust as a reflection of heavy metals distribution in an area with intensively exploited copper minerals, Geologica Macedonica, 25 (2011), pp. 1-9.

[92] B. Balabanova, T. Stafilov, R. Šajn, K. Bačeva, Characterisation of heavy metals in lichen species Hypogymnia physodes and Evernia prunastri due to biomonitoring of air pollution in the vicinity of copper mine, Int. J. Environ. Res., 6 (2012), pp. 779-792.

[93] B. Balabanova, T. Stafilov, R. Šajn, K. Bačeva, Comparison of response of moss, lichens and attic dust to geology and atmospheric pollution from a copper mine, Int. J. Environ. Sci. Technol., 11 (2014), pp. 517-528.

[94] Z. Jeran, R. Jačimović, F. Batič, R. Mavsar, Lichens as integrating air pollution monitors, Environ. Pollut., 120 (2002), pp. 107-113.

[95] S. A. Pirintsos, T. Matsi, D. Vokou, C. Gaggi, S. Loppi, Vertical distribution patterns of trace elements in an urban environment as reflected by their accumulation in lichen transplants, J. Atmos. Chem., 54 (2006), pp. 121-131.

[96] M. Bačkor, S. Loppi, Interactions of lichens with heavy metals, Biol. Plantarum., 53 (2009), pp. 214 222.

[97] B. J. Williamson, I. Mikhailova, O. W. Purvis, V. Udachin, SEM-EDX analysis in the source apportionment of particulate matter on Hypogymnia physodes lichen transplants around the $\mathrm{Cu}$ smelter and former mining town of Karabash, South Urals, Russia, Sci. Total Environ., 322 (2004), pp. 139154.

[98] B. Balabanova, T. Stafilov, K. Bačeva, I. Vučković, Heavy metals toxicity and bioaccumulation in vegetables from potentially polluted area, Sci. Works Agric. Univ. Plovdiv, 60 (2013), pp. 615-620.

[99] N. Rascio, F. Navari-Izzo, Heavy metal hyperaccumulating plants: How and why do they do it? And what makes them so interesting?, Plant Sci., 180 (2011), pp. 169-181.
[100] B. Balabanova, T. Stafilov, R. Šajn, K. Bačeva, Quantitative assessment of metal elements using moss species as biomonitors in downwind area of one lead-zinc mine, J. Environ. Sci., 26(7) (2014); DOI: $10.1016 /$ S1001-0742(13)60561-6.

[101] T. Serafimovski, T. Dolenec, G. Tasev, New data concerning the major ore minerals and sulphosalts from the $\mathrm{Pb}-\mathrm{Zn}$ Zletovo mine, Macedonia. $R M Z$ Mater. Geoenviron., 52 (2006), pp. 535-548.

[102] T. Stafilov, B. Krstev, Z. Karamanolevski, M. Kočubovski, M. Spirovska, Monitoring of Tailings Disposal Site for Evacuation of Wastewater to the Sedimentation Pond and System for Evacuation of Surrounding Waters and Their Impacts on the Environment Along the Course of Kamenicka River, Kalimanci Accumulation and Bregalnica River, Final Report, Ministry of Environment and Physical Planning of the Republic of Macedonia, Skopje, 2005.

[103] P. Vrhovnik N. R. Šmuc, T. Dolenec, T. Serafimovski, M. Dolenec, Impact of $\mathrm{Pb}-\mathrm{Zn}$ mining activity on surficial sediments of Lake Kalimanci (Macedonia), Turk. J. Earth Sci., 22 (2013), pp. 114.

[104] B. Balabanova, T. Stafilov, R. Šajn, Variability assessment for multivariate analysis of elemental distributions due to anthropogenic and geogenic impact in lead-zinc mine and flotation environ (moss sampling media), Int. J. Environ. Poll., (2014).

[105] T. Dolenec, T. Serafimovski, G. Tasev, M. Dobnikar, M. Dolenec, Heavy metals contamination in paddy soil irrigated with the acid mine drainageimpacted Zletovska River (Kočani Field, Republic of Macedonia), Proceedings on the 2nd International Workshop on the UNESCO-IGCP Project "Anthropogenic Effects on the Human Environment in Tertiarry Basins in the Mediterranean", Faculty of Natural Sciences and Engineering, Ljubljana, 2005, pp. 16-20.

[106] S. Angelovska, T. Stafilov, R. Šajn, K. Bačeva, B. Balabanova, Moss biomonitoring of air pollution with heavy metals in the vicinity of $\mathrm{Pb}-\mathrm{Zn}$ mine "Toranica" near the town of Kriva Palanka, Mod. Chem. Appl., 2(1) 123, pp.1-6 (2014).

[107] T. Serafimovski, T. Dolenec, G. Tasev, Actinolitephengite-chlorite metasomatites from the Toranica $\mathrm{Pb}-\mathrm{Zn}$ ore deposit in Macedonia. RMZ Mater. Geoenviron., 53 (2006), pp. 445-453.

[108] M. G. Dobrovolskaya, R. Stankovski, Structuraltextural relations and succession of ore deposition in the Toranica $\mathrm{Pb}-\mathrm{Zn}$ deposit (Macedonia). Geol. Ore Deposit C, 39 (1997), pp. 79-92.

[109] M. Yossifova, C. Lerouge, Y. Deschamps, T. Serafimovski, G. Tasev, Inorganic Chemical Chracterization of the Bitola, Oslomej, and Berovo Coals and their Waste Products from Burning, GeoLines, 29 (2009), pp. 95-102. 
[110] B. Dimovska, T. Stafilov, R. Šajn, C. Tănăselia, Moss biomonitoring of air pollution with arsenic in Bitola and its environs, Republic of Macedonia, Geologica Macedonica, 27 (2013), pp. 5-11.

[111] B. Dimovska, T. Stafilov, R. Šajn, K. Bačeva, Distribution of lead and zinc in soil over the Bitola region, Republic of Macedonia, Geologica Macedonica, 28(1), pp. 87-91 (2014).

[112] C. Johansson, M. Norman, L. Burman, Road traffic emission factors for heavy metals, Atmos. Environ., 42 (2009), pp. 4681-4688.

[113] C. Stuhlberger (Ed.), Mining and Environment in the Western Balkans, UNEP, Geneva, 2009, p. 108 (http://www.unep.org/pdf/MiningBalkans_screen. pdf).

[114] B. Dimovska, R. Šajn, T. Stafilov, K. Bačeva, C. Tănăselia, Determination of atmospheric pollution around the thermoelectic power plant using a moss biomonitoring, Air Quality, Atmosphere \& Health, (2014), DOI: 10.1007/s11869-014-0257-8.

[115] J. A. Walker, Zinc, Mineral Commodity Profile No. 9, New Brunswick Department of Energy and Mines, Minerals and Petroleum Division, Fredericton, New Brunswick, Canada, 2013.

[116] T. Stafilov, R. Šajn, F. Sulejmani, K. Bačeva, Geochemical Atlas of Kičevo and the Environs, Faculty of Natural Sciences and Mathematics, Skopje, 2011.

[117] T. Stafilov, R. Šajn, F. Sulejmani, K. Bačeva, Geochemical properties of topsoil around the open coal mine and Oslomej thermoelectric power plant, R. Macedonia, Geologica Croatica, 67 (2014), pp. 33-44.

\title{
ЗАГАДУВАЊЕ НА ЖИВОТНАТА СРЕДИНА СО ТЕШКИ МЕТАЛИ ВО РЕПУБЛИКА МАКЕДОНИЈА
}

\author{
Трајче Стафилов \\ Институт за хемија, Природно-математички факултет, Универзитет „Св. Кирил и Методиј“, \\ Скопје, Република Македонија
}

Презентирани се резултатите од примената на различни спектрометриски (атомска апсорпциона спектрометрија, AAS; атомска емсиона спектрометрија со индуктивно спрегната плазма, ICP-AES; масена спектрометрија со индуктивно спрегната плазма, ICP-MS) и радиоаналитички (неутронска активациона анализа, NAA) техники за испитување на загадување на животната средина во Република Македонија. Прикажани се резултатите од истражувањата на загадувањето со тешки метали на почвите, воздухот и храната. Дополнително е истражувано загадувањето со тешки метали на посебни региони во Македонија користејќ́ примероци од мов, лишаи, поткровна прашина и почви. Прикажани се резултатите од испитувањата на загадувањето на градовите Велес (топилница за олово и цинк), Кавадарци (топилница за фероникел), Радовиш (рудник и флотација за бакар), Пробиштип, М. Каменица и Крива Паланка (рудници и флотации за олово и цинк) и Битола и Кичево (термоелектрични централи).

Клучни зборови: тешки метали, загадување, воздух, почви, Република Македонија 
